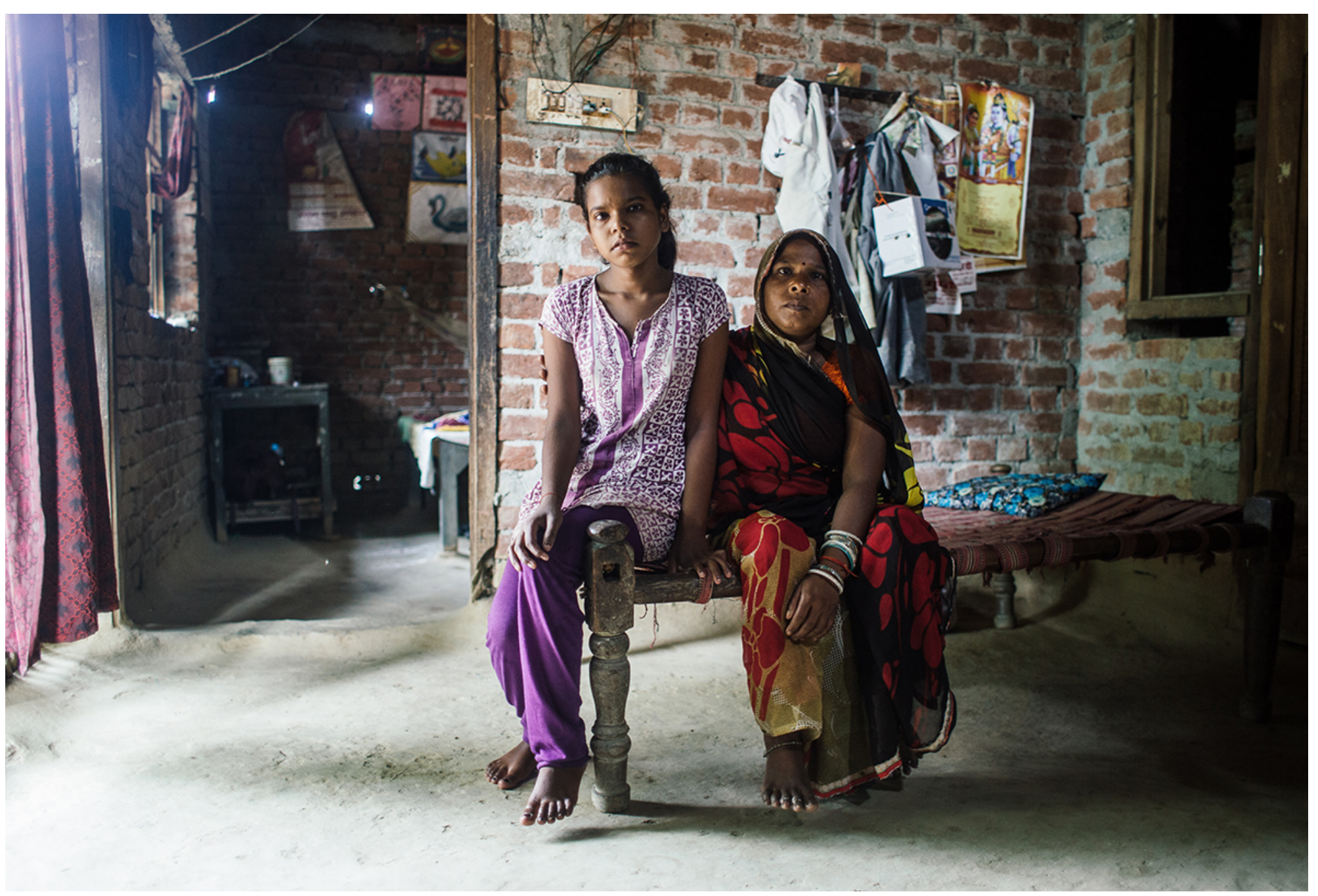

\title{
Prescription for Poverty
}

Drug companies as tax dodgers, price gougers, and influence peddlers

SEPTEMBER 2018

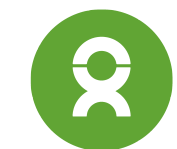

OXFAM 


\section{Background}

New Oxfam research shows that four pharmaceutical corporations-Abbott, Johnson \& Johnson, Merck, and Pfizer-systematically stash their profits in overseas tax havens. They appear to deprive developing countries of more than $\$ 100$ million every year-money that is urgently needed to meet the health needs of people in these countries-while vastly overcharging for their products. And these corporations deploy massive influencing operations to rig the rules in their favor and give their damaging behavior a veneer of legitimacy. Tax dodging, high prices, and influence peddling by drug companies exacerbate the yawning gap between rich and poor, between men and women, and between advanced economies and developing ones.

Cover image: Sushmita (left, now 13 and shown here with her mother) was 3 when she got Japanese encephalitis, a mosquito-borne disease, in India's northern Gorakhpur province. Sushmita was lucky, she survived. But she can't walk properly and has partly lost use of her hands, making it very difficult for her to write. She wants to do well in school, but struggles to keep up. Japanese encephalitis is endemic in this area of India. Poor public health conditions, lack of safe drinking water and proper sanitation, and few health facilities put young children in danger of Japanese encephalitis and other preventable diseases. More than 1,300 children died at the one hospital in the area in 2017,69 of them in the course of four days when the hospital failed to pay its bill for oxygen the children needed to survive. Lack of investment in public health in India, due in part to corporations avoiding paying their taxes, imperils the lives of people living in poverty and worsens inequality in this area of the country. Photo: Zacharie Rabehi/Oxfam 


\section{Engagement with drug companies}

Oxfam reached out to all of the companies named in this report to share the data we gathered, the methodology we employed, and the findings of our research. We sent them our recommendations, and sought to engage them directly regarding responsible corporate tax practice. We reached out to the major pharmaceutical trade associations named in this report, as well. This report integrates the responses that we received. The corporations neither confirmed nor denied the specific research findings in this report. 


\section{Executive summary}

The world's biggest drug companies are putting poor people's health at risk by depriving governments of billions of dollars in taxes that could be used to invest in health care, and by using their power and influence to torpedo attempts to bring down drug costs and police their behavior.

New Oxfam research shows that four major pharmaceutical firms-Abbott, Johnson \& Johnson, Merck, and Pfizer-systematically stash their profits in overseas tax havens. ${ }^{1}$ As a result, these four corporate giants appear to deprive the United States of $\$ 2.3$ billion annually and deny other advanced economies of $\$ 1.4$ billion. And they appear to deprive the cash-strapped governments of developing countries of an estimated $\$ 112$ million every year-money that could be spent on vaccines, midwives, or rural clinics.

Such tax dodging corrodes the ability of governments everywhere to provide the public services that are essential to reducing poverty and that are particularly important for women. And it weakens governments' ability to invest in health research, which has proven to be fundamental to medical breakthroughs.

As if this weren't enough, the corporations mount massive lobbying operations to give price gouging and tax dodging a veneer of legitimacy. Their influence peddling is most blatant in the United States, where the pharmaceutical industry outspends all others on lobbying. But it is equally pernicious in developing countries, where the companies have won sweetheart deals that lower their taxes and divert scarce public health dollars to pay for their high-priced products-and where they deploy the clout of the US government to protect their profits.

Tax dodging by pharmaceutical companies is enriching wealthy shareholders and company executives at the expense of us all-with the highest price paid by poor women and girls.

Oxfam is not accusing the drug companies of doing anything illegal. Rather, this report exposes how corporations can use sophisticated tax planning to take advantage of a broken system that allows multinational corporations from many different industries to get away with avoiding taxes.

When funding is cut, families lose medical care or are driven further into poverty by health care debts. When health systems crumble, women and girls step into the breach to provide unpaid care for their loved ones-compromising their own health and their prospects for education and employment. When governments are deprived of corporate tax revenues, they often seek to balance the budget by raising consumption taxes, which tend to take a larger bite out of poor women's incomes.

Corporations should be more transparent about where they earn their money, they should pay tax in alignment with actual economic activity, rather than abusing tax havens, and they should use their political influence responsibly, rather than undermining governments' efforts to provide medicines, schools, and roads for us all.

\section{Tax dodging}

Oxfam examined publicly available data on subsidiaries of four of the largest US drug companies and found a striking pattern. ${ }^{2}$ In the countries analyzed that have standard corporate tax rates, rich or poor, the corporations' pretax profits were low. In eight advanced economies, drug company profits averaged 7 percent, while in seven developing countries they averaged 5 percent. Yet globally, these corporations reported annual global profits of up to 30 percent. $^{3}$ So where were the high profits? Tax havens. In four countries that charge low or no corporate tax rates, these companies posted skyrocketing 31 percent profit margins. ${ }^{4}$ 
While the information is far from complete, the pattern is consistent: this is either an astounding coincidence or the result of using accounting tricks to deliberately shift profits from where they are actually earned to tax havens. Pfizer, Merck, and Abbott are among the 20 US corporations with the greatest number of subsidiaries in tax havens; Johnson \& Johnson is not far behind. ${ }^{5}$ All four were among the US corporations with the most money stashed overseas: at the end of 2016, these four companies alone held an astounding \$352 billion offshore. ${ }^{6}$

Profits can vary from country to country for any number of reasons, aside from the deliberate shifting of profits to avoid tax. Corporations may have higher transportation costs in some markets, for example, or employ more people. But it is highly unlikely that these explanations can fully account for the consistent pattern of much higher profits being posted in countries with very low tax rates where these corporations do not sell the majority of their medicines.

Pharma corporations' "profit-shifting" may take the form of "domiciling" a patent or rights to its brand not where the drug was actually developed or where the firm is headquartered, but in a tax haven, where a company's presence may be as little as a mailbox. That tax haven subsidiary then charges hefty licensing fees to subsidiaries in other countries. The fees are a tax-deductible expense in the jurisdictions where taxes are standard, while the fee income accrues to the subsidiary in the tax haven, where it is taxed lightly or not at all. Loans from tax-haven subsidiaries and fees for their "services" are other common strategies to avoid taxes.

Recent research by tax economist Gabriel Zucman estimates that nearly 40 percent of all multinational corporate profits were artificially shifted to tax havens in 2015-one of the major drivers of declining corporate tax payments worldwide. ${ }^{7}$

Drug companies are masters at taking advantage of the global "race to the bottom" on tax. Both corporations and governments are to blame. A dysfunctional international tax system allows multinational companies to artificially shift their profits away from where they sell and produce their products to low-tax jurisdictions. Companies are only too glad to take advantage of the broken system-and to invest millions in lobbying to further tilt the playing field in their favor.

Figure 1: Comparison of drug company profit margins

\begin{tabular}{|l|r|r|r|}
\hline & $\begin{array}{c}\text { Number of } \\
\text { subsidiaries } \\
\text { examined }\end{array}$ & Annual revenue & $\begin{array}{c}\text { Average profit } \\
\text { margin }\end{array}$ \\
\hline Belgium & 27 & $\$ 10,704,778,846$ & $10 \%$ \\
\hline Ireland & 21 & $\$ 15,273,508,057$ & $43 \%$ \\
\hline Netherlands & 25 & $\$ 65,899,690,416$ & $34 \%$ \\
\hline Singapore & 11 & $\$ 20,471,300,000$ & $25 \%$ \\
\hline Tax havens & $\mathbf{8 4}$ & $\$ 112,349,277,319$ & $31 \%$ \\
\hline Chile & 3 & $\$ 753,007,000$ & $4 \%$ \\
\hline Colombia & 10 & $\$ 1,329,188,480$ & $12 \%$ \\
\hline
\end{tabular}




\begin{tabular}{|l|r|r|r|}
\hline & $\begin{array}{c}\text { Number of } \\
\text { subsidiaries } \\
\text { examined }\end{array}$ & Annual revenue & $\begin{array}{c}\text { Average profit } \\
\text { margin }\end{array}$ \\
\hline Ecuador & 7 & $\$ 229,945,819$ & $1 \%$ \\
\hline India & 17 & $\$ 2,324,566,184$ & $-1 \%$ \\
\hline Pakistan & 2 & $\$ 99,627,944$ & $16 \%$ \\
\hline Peru & 5 & $\$ 367,616,751$ & $16 \%$ \\
\hline Thailand & 9 & $\$ 963,702,079$ & $9 \%$ \\
\hline Developing & 53 & $\$ 6,067,654,257$ & $\mathbf{5} \%$ \\
\hline countries & 11 & $\$ 3,320,757,458$ & $-7 \%$ \\
\hline Australia & 11 & $\$ 506,090,582$ & $-22 \%$ \\
\hline Denmark & 35 & $\$ 8,807,562,855$ & $10 \%$ \\
\hline France & 28 & $\$ 9,228,221,535$ & $-1 \%$ \\
\hline Germany & 25 & $\$ 6,001,823,748$ & $6 \%$ \\
\hline Italy & 8 & $\$ 356,232,558$ & $6 \%$ \\
\hline New Zealand & 30 & $\$ 4,959,453,150$ & $20 \%$ \\
\hline Spain & 74 & $\$ 6,501,659,986$ & $11 \%$ \\
\hline UK & 222 & $\$ 39,731,801,873$ & $\mathbf{7}$ \\
\hline Advanced countries & & & \\
\hline
\end{tabular}




\section{Comparison of drug company profit margins}

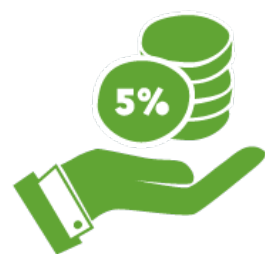

DEVELOPING

COUNTRIES

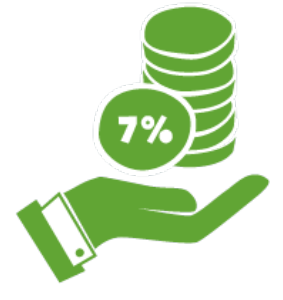

ADVANCED

COUNTRIES

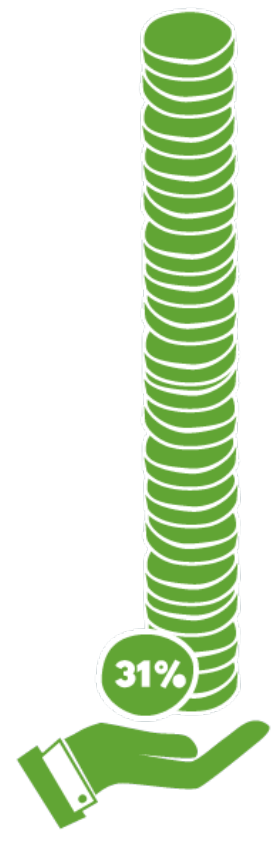

TAX HAVENS

SOURCE: Oxfam analysis of national-level financial filings from four drug companies from 2013 to 2015. For more information, please see this report's "Tax Research Methodology" annex.

More transparency would shed light on how unjust the current system is. None of the four drug companies publish country-by-country reporting (CBCR)-basic financial information for every country in which they operate, including revenue, profits, taxes paid, number of employees, and assets.

Nonetheless, it is possible to use the data that is publicly available to estimate how much tax these companies may be avoiding due to an unequal distribution of profits. In seven developing countries alone-and just from the small sampling of subsidiaries Oxfam was able to access - the four companies may have underpaid $\$ 112$ million in taxes annually between 2013 and 2015, which is more than half of what they actually paid. Johnson \& Johnson may have underpaid \$55 million in taxes every year; Pfizer, \$22 million; Abbott, \$30 million; and Merck, $\$ 5$ million. ${ }^{8}$

Figure 2: Estimated annual tax underpayment in developing countries

\begin{tabular}{|l|c|c|c|c|r|}
\hline & Abbott & J\&J & Merck & Pfizer & \multicolumn{1}{c|}{ TOTAL } \\
\hline Chile & $\$ 4,651,266$ & - & - & - & $\$ 4,651,266$ \\
\hline Colombia & $\$(1,952,883)$ & $\$ 1,088,770$ & $\$ 1,228,112$ & $\$ 11,506,827$ & $\$ 11,870,826$ \\
\hline Ecuador & $\$ 2,168,863$ & - & $\$ 472,655$ & $\$ 2,058,569$ & $\$ \mathbf{\$ 4 7 0 0 , 0 8 7}$ \\
\hline India & $\$ 30,171,485$ & $\$ 41,450,191$ & $\$ 2,296,686$ & $\$(137,778)$ & $\$ \mathbf{\$ 7 3 , 7 8 0 , 5 8 4}$ \\
\hline Pakistan & - & - & - & $\$ 1,654,868$ & $\$ 1,654,868$ \\
\hline
\end{tabular}




\begin{tabular}{|l|r|r|r|r|r|}
\hline & Abbott & J\&J & Merck & Pfizer & TOTAL \\
\hline Peru & $\$(5,191,248)$ & $\$ 1,920,555$ & $\$(1,580,927)$ & $\$ 1,884,431$ & $\mathbf{\$ ( 2 , 9 6 7 , 1 8 8 )}$ \\
\hline Thailand & $\$ 632,044$ & $\$ 10,174,664$ & $\$ 3,049,057$ & $\$ 4,799,166$ & $\mathbf{\$ 1 8 , 6 5 4 , 9 3 2}$ \\
\hline $\begin{array}{l}\text { Developing } \\
\text { countries }\end{array}$ & $\mathbf{\$ 3 0 , 4 7 9 , 5 2 7}$ & $\mathbf{\$ 5 4 , 6 3 4 , \mathbf { 1 8 0 }}$ & $\mathbf{\$ 5 , 4 6 5 , 5 8 4}$ & $\mathbf{\$ 2 1 , 7 6 6 , 0 8 3}$ & $\mathbf{\$ 1 1 2 , 3 4 5 , 3 7 4}$ \\
\hline $\begin{array}{l}\text { Note: Numbers in parentheses are negative; they indicate where the national-level profit } \\
\text { margin was higher than the global average profit margin. Entries without a number } \\
\text { indicate that no country-level financial information was available. }\end{array}$ \\
\hline \multicolumn{7}{|l}{} \\
\hline
\end{tabular}

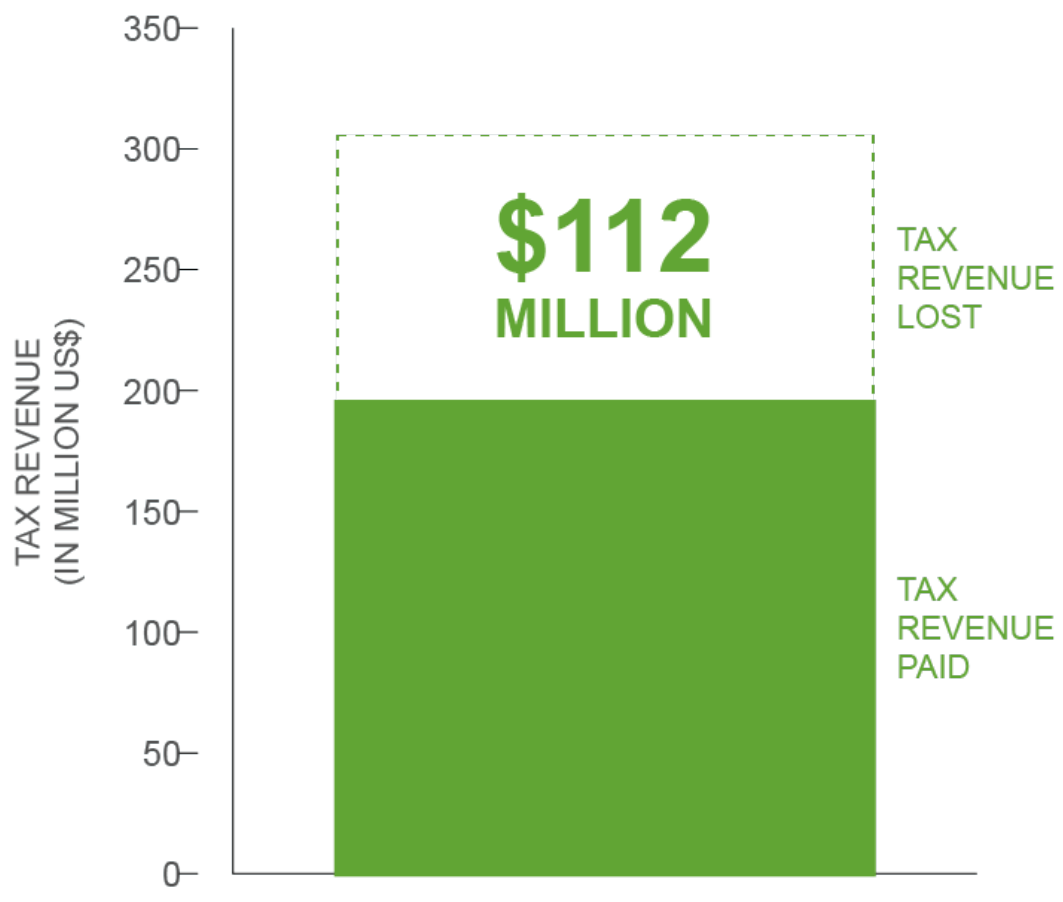

SOURCE: Oxfam analysis of national-level financial filings from four drug companies from 2013 to 2015 . Estimated tax underpayment represents the difference between the taxes these companies would pay under a system that apportions global profits equally across countries and the taxes these companies report they actually paid. For more information, please see this report's "Tax Research Methodology" annex.

These amounts are pocket change to these corporate behemoths. But they represent significant losses to low-income and middle-income countries. Developing countries could use the money to address the yawning gaps in public health services that keep many of the poorest people in the world from lifting themselves out of poverty.

The HPV vaccine is one example. Human papilloma virus (HPV) is a sexually transmitted infection $^{9}$ that can cause cervical cancer, the fourth-most-common cancer among women worldwide and the second-most-common cancer in women living in less developed regions. ${ }^{10}$ HPV kills 300,000 people every year; ${ }^{11}$ every two minutes a life is lost to this disease, and nine out of 10 of these deaths are women in low- and middle-income 
countries. ${ }^{12}$ For example, in India, 67,477 women died of cervical cancer in $2012 .{ }^{13}$ The HPV vaccine drastically reduces the incidences of HPV and cervical cancer. ${ }^{14}$

The amount of money we estimate these companies may have avoided in tax is enough to buy vaccines for more than 10 million girls, about two-thirds of the girls born in 2016 in the seven developing countries Oxfam examined.$^{15}$ India could buy HPV vaccines for 8.1 million girls, which is 65 percent of the girls born in $2016 .{ }^{16}$ In Thailand, where 4,500 women die each year from cervical cancer, the $\$ 18.65$ million in taxes we estimate these companies underpaid per year would be enough to pay for HPV vaccines for more than 775,000 girls, more than double the number born in $2016 .{ }^{17}$

\section{Figure 3: Potential impact on women and girls}

Oxfam estimates that

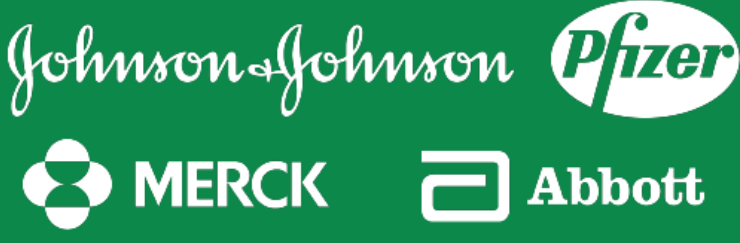

may have underpaid taxes by $\$ 112,000,000$

Which could buy HPV vaccines for 11

2 out of every 3 girls born
Chile

Colombia

Ecuador

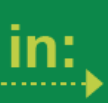

India

Pakistan

Peru

Thailand

One might think that pharmaceutical profits really are lower in poorer countries, where purchasing power is small and drugs are sold at a discount. But the data indicates a different story. In advanced economies with larger markets and ample purchasing power, the drug companies' profit margins are just as slim as in developing countries. The corporations may have avoided even more in taxes in these larger markets, a total of nearly $\$ 3.7$ billion annually-equivalent to two-thirds of the $\$ 5$ billion they actually paid. Johnson \& Johnson led the pack with an estimated $\$ 1.7$ billion underpaid annually. Pfizer may have underpaid by $\$ 1.1$ billion, Merck $\$ 739$ million, and Abbott $\$ 169$ million. ${ }^{18}$

Figure 4: Estimated annual tax underpayment in advanced economies

\begin{tabular}{|l|r|r|r|r|r|}
\hline & \multicolumn{1}{|c|}{ Abbott } & \multicolumn{1}{c|}{ J\&J } & \multicolumn{1}{c|}{ Merck } & \multicolumn{1}{c|}{ Pfizer } & \multicolumn{1}{c|}{ Total } \\
\hline Australia & $\% 5,548,718$ & $\$ 70,987,178$ & $\$ 16,616,610$ & $\$ 72,054,671$ & $\mathbf{\$ 1 6 5 , 2 0 7 , 1 7 6}$ \\
\hline Denmark & $\$ 122,685$ & $\$ 5,578,635$ & $\$ 2,591,097$ & $\$ 13,265,165$ & $\mathbf{\$ 2 1 , 5 5 7 , 5 8 1}$ \\
\hline
\end{tabular}




\begin{tabular}{|c|c|c|c|c|c|}
\hline & Abbott & J\&J & Merck & Pfizer & Total \\
\hline France & $\$ 13,018,931$ & $\$ 197,518,429$ & $\$ 51,084,419$ & $\$ 157,117,977$ & $\$ 418,739,756$ \\
\hline Germany & $\$ 5,123,061$ & $\$ 159,095,358$ & $\$ 52,651,783$ & $\$ 99,845,535$ & $\$ 316,715,737$ \\
\hline Italy & $\$ 14,083,238$ & $\$ 94,977,531$ & $\$ 25,229,356$ & $\$ 133,662,556$ & $\$ 267,952,681$ \\
\hline $\begin{array}{l}\text { New } \\
\text { Zealand }\end{array}$ & $\$ 1,008,107$ & $\$ 7,210,106$ & $\$ 2,090,100$ & $\$ 3,546,806$ & $\$ 13,855,119$ \\
\hline Spain & $\$(7,126,288)$ & $\$ 58,868,644$ & $\$ 32,629,391$ & $\$(92,081,397)$ & $\$(7,709,649)$ \\
\hline UK & $\$(5,541,997)$ & $\$ 96,566,015$ & $\$ 22,977,313$ & $\$ 80,969,794$ & $\$ 194,971,125$ \\
\hline USA* & $\$ 143,000,000$ & $\$ 1,046,000,000$ & $\$ 533,000,000$ & $\$ 589,000,000$ & $\$ 2,311,000,000$ \\
\hline \multirow[t]{3}{*}{ TOTAL } & $\$ 168,758,452$ & $\$ 1,737,088,396$ & $\$ 738,988,819$ & $\$ 1,057,384,274$ & $\$ 3,702,219,942$ \\
\hline & \multicolumn{5}{|c|}{$\begin{array}{l}\text { Note: Numbers in parentheses are negative; they indicate where the national-level } \\
\text { profit margin was higher than the global average profit margin. }\end{array}$} \\
\hline & \multicolumn{5}{|c|}{$\begin{array}{l}\text { * The numbers for the United States were calculated using a slightly different } \\
\text { methodology because the companies do report consolidated financial information } \\
\text { for the US, but not other countries. See this report's "Tax Research Methodology" } \\
\text { annex for details. }\end{array}$} \\
\hline
\end{tabular}

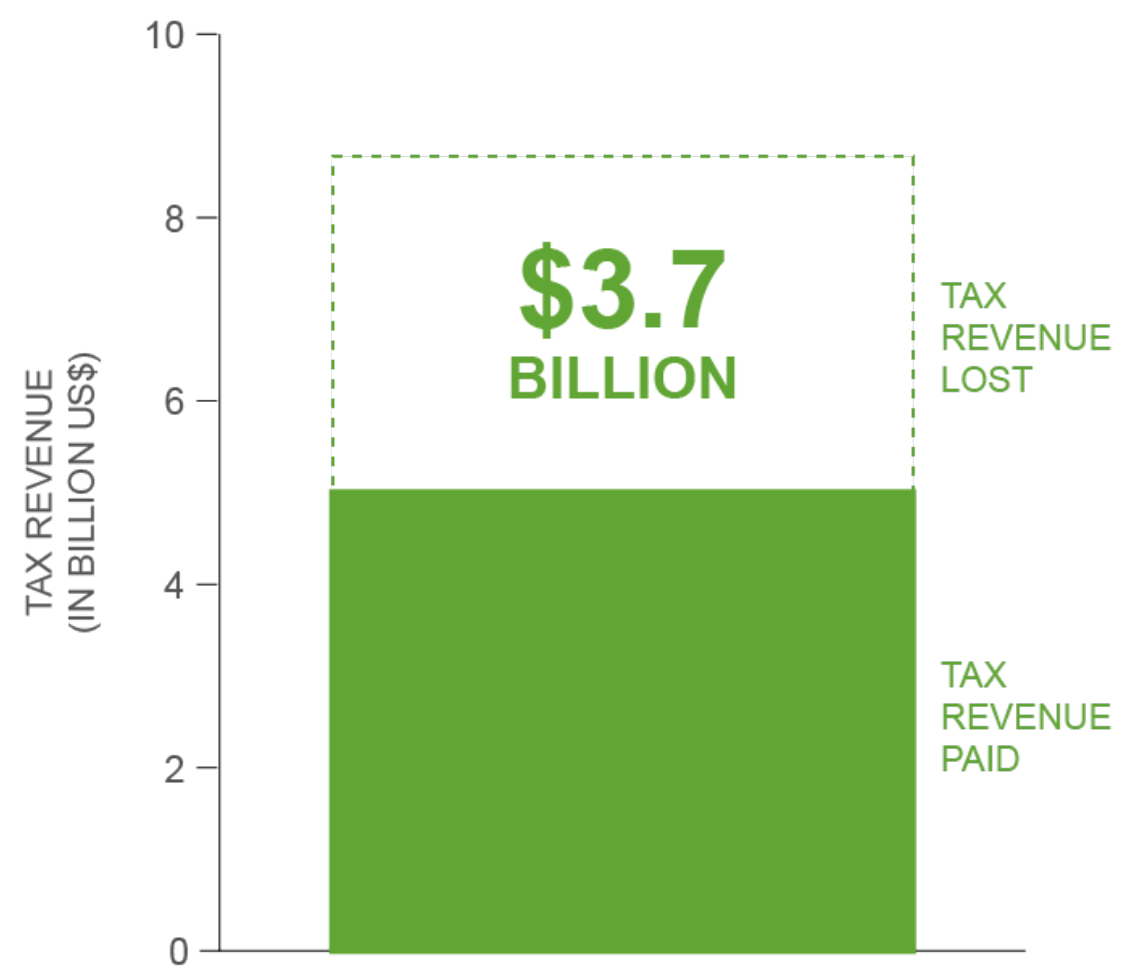

SOURCE: Oxfam analysis of national-level financial filings from four drug companies from 2013 to 2015 . Estimated tax underpayment represents the difference between the taxes these companies would pay under a system that apportions global 
profits equally across countries and the taxes these companies report they actually paid. For more information, please see this report's "Tax Research Methodology" annex.

\section{Influence peddling}

Perhaps even more galling than these corporations' sophisticated tax avoidance is their subversion of democratic politics. Year after year pharmaceutical corporations spend the most of any industry on influencing the US government, more than $\$ 200$ million annually. ${ }^{19}$ They employ the most lobbyists and donate millions of dollars to politicians' campaigns. They are also adept at placing their own people in powerful government posts.

For example, the current US secretary of health and human services, a Cabinet-level post that oversees government health care policy, is Alex Azar, who led Eli Lilly between 2012 and 2017. The US Trade Representative, whose mandate includes pressuring countries that have policies the United States believes hinder drug company profits, is Robert Lighthizer, who most recently worked at the law firm representing Pfizer, Merck, and Abbott, among others. $^{20}$

The pharmaceutical industry has the largest network of people working for a special interest in the United States: an army of 1,500 agents representing professional lobby firms in 2017, equivalent to 13 percent of all lobbyists. ${ }^{21}$ Most of this workforce is made up of former members of Congress and former high-ranking federal employees, who use their government experience and connections to advocate. ${ }^{22}$ Among drug companies, Pfizer is consistently a top lobby spender, ranking second in 2017 at $\$ 10.4$ million. Johnson \& Johnson (\$6.9 million) and Merck (\$6.2 million) ranked sixth and seventh, respectively, while Abbott (\$4.2 million) ranked 13th.

Between 2010 and 2016, the main trade association of these corporations, Pharmaceutical Researchers and Manufacturers of America (PhRMA), donated \$1.8 million to candidates for Congress representing both major parties, double what the US Chamber of Commerce provided. ${ }^{23}$ But the bulk of contributions came from pharma companies and their political action committees (PACs). The four companies Oxfam studied donated a total of $\$ 43.9$ million during those years: $\$ 17.6$ million by Pfizer, $\$ 11.6$ million by Abbott, $\$ 9.5$ million by Merck, and $\$ 5.2$ million by Johnson \& Johnson. ${ }^{24}$

Pharmaceutical corporations have also used their influence to get the US government to pressure developing countries on their behalf. The threat of US sanctions will often suffice to convince finance and trade ministers to overrule attempts by health officials to make medicines affordable or by tax officials to rein in pharma's tax dodging.

For example, the United States recently threatened to block Colombia's accession to the Organization for Economic Cooperation and Development (OECD) if it did not conform to stronger levels of monopoly protections for medicines, after having previously threatened to withhold assistance for Colombia's peace process unless it dropped its tentative moves to issue a compulsory license to lower the price of a cancer medicine. ${ }^{25}$ Free trade agreements are another means of influence where the US and EU push for measures that ensure stricter intellectual property (IP) rules that limit governments' ability to protect public health and lower the price of medicines.

Such pressure presents developing country governments with an untenable choice: either ensure access to medicines for their citizens or increase trade to promote economic growth. Governments need to do both if they are to reduce poverty and inequality.

The companies also engage in clever grassroots campaigns. When a medicine is excluded from eligibility for government purchase due to its exorbitant price, those complaining loudly in the press are often not the companies, but rather nonprofit "patients' rights" 
organizations-which often turn out to be funded by the corporations. Twelve major pharmaceutical companies, including Abbott, Johnson \& Johnson, Merck, and Pfizer, fund more than 65 such groups in Latin America, as well as their umbrella, the International Alliance of Patients' Organizations. ${ }^{26}$

\section{Profits and innovation}

Tax dodging, high prices, and influence peddling help explain the extreme profitability of these companies-and the extreme benefits they offer their wealthy shareholders and senior executives. The 25 largest US drug companies had global annual average profit margins of between 15 and 20 percent in the period 2006-2015; the figure for comparable nondrug companies was 4 to 9 percent. ${ }^{27}$ These high profits, in turn, increase the incentive that these corporations have to shift profits and avoid tax.

The current system for biomedical research and development (R\&D), a cornerstone of these corporations' business model, is based on monopoly protection secured by intellectual property rules as pharmaceutical companies invest in development of products that can produce the highest profit. The IP-based system of R\&D has failed to produce many medicines needed for public health. For example, there has been no new class of antibiotics developed since 1987 despite the rising problem of antimicrobial resistance. ${ }^{28}$

The companies claim they need superprofits so they can invest in discovering new medicines to treat the world's ailments, but this simply isn't true. Big drug companies spend more on whopping payouts to shareholders and executives than on research and development. In the decade from 2006 to 2015 , they spent $\$ 341.4$ billion of their $\$ 1.8$ trillion in revenue on stock buybacks and dividends-equivalent to 19 percent. They spent $\$ 259.4$ billion on R\&D, or only 14 percent. ${ }^{29}$ What's more, R\&D expenses are tax deductible.

The cost of medicines, many of which were originally set at exorbitant prices, has continued to rise dramatically, with seven of the nine best-selling drugs sold by Pfizer, Merck, and Johnson \& Johnson seeing double-digit price increases in $2017 .^{30}$ For example, Pfizer raised the price of Lyrica-which treats diabetic nerve pain, has no generic competition, and generated $\$ 4.5$ billion for the company in sales last year-by more than 29 percent in $2017 .{ }^{31}$

New medicines are also set at sky-high prices from the start. Take, for example, Ibrance, a drug for metastatic breast cancer, which Pfizer put on the market for nearly $\$ 10,000$ per month. ${ }^{32}$ These high prices are unaffordable in the US, where medical costs are the primary reason for individual bankruptcy. ${ }^{33}$ In low- and middle-income countries, such outrageous prices break public health budgets and place the burden of paying on sick people and their families, who cannot afford it. As another example, a new medicine to treat multidrugresistant tuberculosis, bedaquiline, was priced by Janssen-a subsidiary of Johnson \& Johnson in South Africa-at $\$ 400$ for the six-month course, which makes it unaffordable for most who need it, especially galling when researchers estimate a generic equivalent of the medicine could be made available for only $\$ 48 .{ }^{34}$

In recognition of the global nature of this crisis in access to medicines, the UN SecretaryGeneral set up a High-Level Panel on Access to Medicines that produced a report containing important recommendations to ensure innovation and access to medicines. ${ }^{35}$ Oxfam has called on governments and international health organizations to fully implement the recommendations of the High-Level Panel. ${ }^{36}$

Even while Pfizer hiked the price of dozens of drugs, the total compensation of Pfizer's CEO leaped up by 61 percent in 2017, to $\$ 26.2$ million. That year Johnson \& Johnson's CEO earned \$22.8 million, Merck's earned \$17.1 million, and Abbott's earned \$15.6 million. ${ }^{37}$ The 
average compensation for a drug company CEO in 2015 was $\$ 18.5$ million, 71 percent greater than the median earned by executives in all industries. ${ }^{38}$

The companies' R\&D spending is also smaller than the billions they spend on marketing. In 2013, Johnson \& Johnson spent more than twice as much on sales and marketing than on R\&D ( $\$ 17.5$ billion vs. $\$ 8.2$ billion). Pfizer nearly did as well ( $\$ 11.4$ billion vs. $\$ 6.6$ billion), and Merck spent 20 percent more ( $\$ 9.5$ billion vs. $\$ 7.5$ billion). ${ }^{39}$ These marketing costs are also tax deductible.

The reality is that the taxpayer-funded National Institutes of Health in the United States is by far the largest investor in health research, with European governments providing substantial funding, as well. ${ }^{40}$ All 210 drugs approved in the United States between 2010 and 2016 benefited from publicly funded research, either directly or indirectly. ${ }^{41}$ The source for these public investments, of course, is taxes. Patients thus often pay twice for medicines: through their tax dollars and at the pharmacy-or three times if we count the extra tax dollars we pay because the companies don't. ${ }^{42}$

\section{Corporate social responsibility}

Pharmaceutical corporations paint themselves as noble scientists leading the charge against disease. Pfizer's code of conduct says: "Integrity is more than just complying with the law. It is one of our core values." ${ }^{43}$ Johnson \& Johnson's corporate credo states: "We must be good citizens-support good works and charities and bear our fair share of taxes." ${ }^{\prime 4}$

Unfortunately, the reality of these corporations' business practices bears little resemblance to this rhetoric.

These companies should choose the high road. Rather than engage in elaborate schemes to hide their profits, they must pay their taxes in an open and transparent way. After all, the companies' very profitability depends on publicly funded research, public drug certification, public procurement, and public protection of intellectual property.

Governments must do more to reverse their race to the bottom on taxation. They must mandate basic transparency measures that would prevent abuse by multinationals. They must also open up budget and spending processes to citizens to ensure that public spending meets citizen priorities. Oxfam's Fiscal Accountability for Inequality Reduction (FAIR) program supports citizen engagement in government decisions on taxes, budgets, and expenditures, including on health, in dozens of countries around the world. ${ }^{45}$

Governments must allocate sufficient available public resources to important social services, and citizens must engage governments to ensure that budget decisions reflect citizen priorities, including access to affordable health care. Serious coordinated action is essential if we are to unravel the global web of secrecy that encourages rich corporations to avoid paying their fair share. Women and men around the world are standing up and calling for better and fairer tax and health systems, and we stand shoulder to shoulder with them.

\section{The way forward}

Tax dodging, high prices, and influence peddling clearly victimize the most vulnerable. ${ }^{46}$ Abbott, Johnson \& Johnson, Merck, and Pfizer funnel superprofits from people living in poverty to wealthy shareholders and corporate executives, driving ever wider the gap between the richest and the rest.

As with most drivers of inequality, exorbitant drug prices, aggressive tax avoidance, and excessive lobbying are not accidental. They result from deliberate choices made by companies and by the politicians under their sway. It is our hope that this report will encourage the four companies and others to reform their policies and practices, and that it 
will spur governments to enact rules that promote responsibility and benefit all society. We believe such a change is in the companies' long-term interest. Just as extreme inequality is toxic for society, undermining public institutions is no recipe for a stable, profitable industry.

\section{Oxfam's recommendations \\ We call on companies to:}

Be more transparent by publishing all information necessary for citizens to understand and assess the company's tax practices.

- Publish full country-by-country reporting (CBCR) of key financial information.

- Publish a full list of all company subsidiaries in every country where they operate.

Pay their fair share by aligning tax payments with actual economic activity.

- Publicly commit to pay tax on profits where value is created and economic activity takes place, and to stop artificially shifting profits to low-tax jurisdictions.

- Take concrete steps to progressively align economic activities and tax liabilities, including shutting down subsidiaries in tax havens when a primary purpose of those subsidiaries is to avoid taxation.

Use their influence responsibly to shape a more equitable tax system for sustainable and inclusive growth.

- Publicly commit to advocate for greater transparency, for an end to abusive tax practices, and for stronger international cooperation to stop the dangerous "race to the bottom" on corporate tax.

- Publicly disclose all contributions made to political candidates, policymakers, trade associations, think tanks, coalitions, and other political entities to influence policy in the US and abroad.

- Publicly commit to align the corporations' financial contributions and private advocacy with their credos and codes of conduct on tax policy issues.

- Monitor the impact of their policies, pricing, and other practices on women and girls living in poverty.

Enable access to affordable medicines for all by:

- Publicly declaring actual spending on R\&D, production, and marketing of medicines and committing to full transparency on medicine prices, results of clinical trials, and patent information.

- Publicly declaring support for the UN High-Level Panel on Access to Medicines and its recommendations, including governments' right to use mechanisms in the World Trade Organization (WTO) Agreement on TradeRelated Intellectual Property (known as the TRIPS agreement) to reduce medicine prices, affirming that intellectual property protection must not take precedence over public health needs.

\section{We call on governments to:}

\section{Require companies to adhere to full transparency and pay their fair share of taxes.}

- Mandate and implement public country-by-country financial reporting for all large multinational corporations.

- Require large multinational corporations to pay a fair, effective tax rate on their profits, strengthen rules to discourage profit-shifting, and take action against tax havens. 
Ensure access to medicines for their citizens.

- Require corporations to disclose the cost of R\&D, production, and marketing of medicines before approving product registration.

- Implement the recommendations of the UN High-Level Panel report at the national level and call for implementation by international institutions including the World Health Organization (WHO), the WTO, and the UN.

- Invest in public health services that are free for patients at the point of use.

\section{We call on citizens to:}

Join Oxfam to demand that drug companies stop cheating women and girls out of the chance to beat poverty. 


\section{Introduction}

Tobeka Daki, a single mother of two boys who was also a health activist from Mdantsane township in East London, South Africa, was diagnosed with breast cancer in 2013. In addition to a mastectomy and chemotherapy, she needed a medicine called trastuzumab to improve her chances of survival. In South Africa a 12-month course of trastuzumab costs approximately $\$ 38,000$, around five times the average household income. ${ }^{47}$ Tobeka's chance of survival was denied because neither she nor the public system could afford the medicine. Tobeka's cancer spread to her spine and within three years of diagnosis she was dead.

South Africa is one of the most economic unequal countries in the world. ${ }^{48}$ Most of its citizens (84 percent) depend on the public health sector for their care, and have only limited access to cancer treatments because of their prohibitive costs. ${ }^{49}$ Oxfam has written extensively on the toxic effects of the inequality crisis. The dramatic gap between rich and poor threatens us all.

One of the most pernicious aspects of extreme inequality today plays out in the field of health. Simply for being born poor and a girl, a young woman will have to struggle harder to get an education and a decent job, and she is less likely to get the various forms of health care she needs. She will be one of the millions of people around the world for whom decent health care and medication are unaffordable luxuries only available to the rich.

This report demonstrates the tragic consequences that result when governments don't have the resources they need to invest in the health and well-being of their citizens-resources they raise, in part, through corporate taxation. Multinational pharmaceutical corporations produce lifesaving medicines that are vital to protecting and healing us all. Oxfam's research shows, however, that contrary to the socially responsible image they project in their promotional advertisements, big drug companies avoid paying taxes, contributing to depriving public health care systems across the globe of adequate funding. What's more, they mount massive lobbying operations in an effort to obtain favorable rules and regulations, and to give price gouging and tax dodging a veneer of legitimacy.

Four major pharmaceutical corporations-Abbott, Johnson \& Johnson, Merck, and Pfizersystematically stash their profits in overseas tax havens. Their sophisticated tax avoidance strategies deprive the United States and other advanced economies of billions of dollars, and, our research indicates, may deprive the cash-strapped governments of developing countries of more than $\$ 100$ million every year.

These companies also invest heavily in the Washington political game. Year after year, pharmaceutical corporations spend the most of any industry on influencing the US government. They employ the most lobbyists and donate millions of dollars to politicians' campaigns. They are also adept at placing their own people in powerful government posts. These means of influence have won them sweetheart rules that effectively block efforts to promote the public interest. Pharmaceutical corporations then deploy these same strategies to get the United States to strong-arm foreign nations into giving them similar favorable treatment.

Aggressive tax avoidance by the companies contributes to starving the budgets for public services that have an equalizing effect on society and benefit women in particular. Tax dodging encourages governments to raise a greater proportion of their revenue from taxes on consumption, which take a larger bite out of women's earnings. And when health care systems lack the wherewithal to care for the ill, it is women and girls who step into the 
breach to provide unpaid care for their loved ones-compromising their own health and their prospects for education and employment.

The case of pharmaceutical companies offers insight into how certain elites have shaped the political and economic structures of today's world-and how those structures widen the inequality gap between rich and poor, between men and women, and between advanced economies and developing ones. The intellectual property system, which claims to stimulate innovation for medical breakthroughs, has instead been hijacked to strengthen monopoly power. The tax system, which should help pay for basic public services that level the playing field and offer true equality of opportunity, has been subverted. The democratic political system, which should guarantee the public interest, has been sabotaged. 


\section{Chapter 1: Big pharma, big tax dodger}

Over the course of four days in the summer of 2017, 69 children died after the supply of oxygen to Baba Raghav Das Memorial Medical College and Hospital in Gorakhpur, India, was disrupted, allegedly due to nonpayment of dues to a vendor. ${ }^{50}$ The horrific images and stories of family tragedy brought India's public health and tax challenges into stark relief on the world stage.

Sadly, the 69 lost children are just the tip of the iceberg. A deeper malaise has been killing children in Gorakhpur and in poor communities around the world: underinvestment in health care, sanitation, and clean water.

Governments cannot invest in health without adequate tax revenue. New Oxfam research finds that four of the largest pharmaceutical companies based in the United States-Abbott, Johnson \& Johnson, Merck, and Pfizer-systematically stash their profits in overseas tax havens to avoid paying their fair share of tax. Their aggressive tax avoidance strategies deprive not only the United States and other advanced economies of needed revenue; they appear to deprive the cash-strapped governments of developing countries of more than $\$ 100$ million every year-money urgently required to meet the health needs of their people.

Because the companies reveal little financial information about their subsidiaries, Oxfam's investigation barely scratches the surface. Yet even a small sampling reveals a striking degree of tax dodging. In just seven developing countries-Chile, Colombia, Ecuador, India, Pakistan, Peru, and Thailand-Oxfam estimates that these US drug corporations appear to underpay by an estimated $\$ 112$ million in taxes every year. And in eight wealthy countries, Abbott, Johnson \& Johnson, Merck, and Pfizer may underpay by an estimated \$3.7 billion$\$ 2.3$ billion of it in the United States. ${ }^{51}$

Oxfam also examined these companies' operations in four tax havens, countries that offer either low tax rates or special tax advantages. A clear and consistent pattern emerged: companies report low profit margins in developing countries and advanced economies, and high profit margins in tax havens. To put it another way, the data show an inverse correlation between profit margins and tax rates: low profits in jurisdictions with standard tax rates and high profits in low-tax jurisdictions.

Although the companies' annual global profit margins ranged from 10 percent to 30 percent in 2013-2015, in the eight advanced economies, profits averaged 7 percent, while in the seven developing countries they averaged 5 percent. Yet in the four tax havens, the companies managed to earn a whopping profit margin of 31 percent.

Figure 1: Comparison of drug company profit margins

\begin{tabular}{|l|r|r|r|}
\hline & $\begin{array}{c}\text { Number of } \\
\text { subsidiaries } \\
\text { examined }\end{array}$ & Annual revenue & $\begin{array}{c}\text { Average profit } \\
\text { margin }\end{array}$ \\
\hline Belgium & 27 & $\$ 10,704,778,846$ & $10 \%$ \\
\hline Ireland & 21 & $\$ 15,273,508,057$ & $43 \%$ \\
\hline Netherlands & 25 & $\$ 65,899,690,416$ & $34 \%$ \\
\hline Singapore & 11 & $\$ 20,471,300,000$ & $25 \%$ \\
\hline
\end{tabular}




\begin{tabular}{|c|c|c|c|}
\hline & $\begin{array}{l}\text { Number of } \\
\text { subsidiaries } \\
\text { examined }\end{array}$ & Annual revenue & $\begin{array}{l}\text { Average profit } \\
\text { margin }\end{array}$ \\
\hline Tax havens & 84 & $\$ 112,349,277,319$ & $31 \%$ \\
\hline Chile & 3 & $\$ 753,007,000$ & $4 \%$ \\
\hline Colombia & 10 & $\$ 1,329,188,480$ & $12 \%$ \\
\hline Ecuador & 7 & $\$ 229,945,819$ & $1 \%$ \\
\hline India & 17 & $\$ 2,324,566,184$ & $-1 \%$ \\
\hline Pakistan & 2 & $\$ 99,627,944$ & $16 \%$ \\
\hline Peru & 5 & $\$ 367,616,751$ & $16 \%$ \\
\hline Thailand & 9 & $\$ 963,702,079$ & $9 \%$ \\
\hline $\begin{array}{l}\text { Developing } \\
\text { countries }\end{array}$ & 53 & $\$ 6,067,654,257$ & $5 \%$ \\
\hline Australia & 11 & $\$ 3,320,757,458$ & $-7 \%$ \\
\hline Denmark & 11 & $\$ 506,090,582$ & $-22 \%$ \\
\hline France & 35 & $\$ 8,807,562,855$ & $10 \%$ \\
\hline Germany & 28 & $\$ 9,228,221,535$ & $-1 \%$ \\
\hline Italy & 25 & $\$ 6,001,823,748$ & $6 \%$ \\
\hline New Zealand & 8 & $\$ 356,232,558$ & $6 \%$ \\
\hline Spain & 30 & $\$ 4,959,453,150$ & $21 \%$ \\
\hline UK & 74 & $\$ 6,501,659,986$ & $11 \%$ \\
\hline Advanced countries & 222 & $\$ 39,731,801,873$ & $7 \%$ \\
\hline
\end{tabular}




\section{Comparison of drug company profit margins}

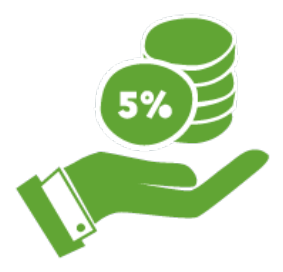

DEVELOPING

COUNTRIES

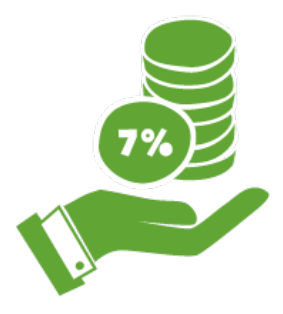

ADVANCED

COUNTRIES

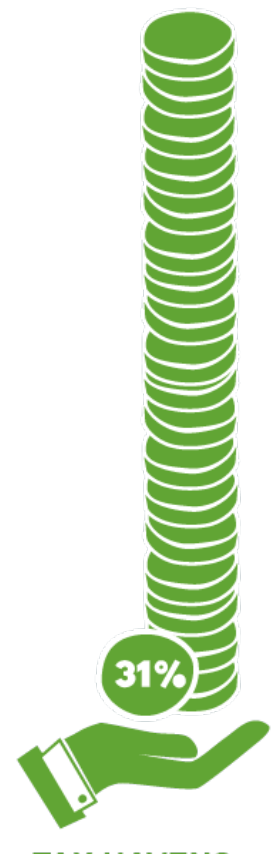

TAX HAVENS

SOURCE: Oxfam analysis of national-level financial filings from four drug companies from 2013 to 2015. For more information, please see this report's "Tax Research Methodology" annex.

A likely explanation for the peculiar pattern of high profits where taxes are low and low profits where they are normal is a practice known as profit-shifting. In the case of the pharmaceutical giants, the ploy may involve "domiciling" a patent, not in the corporation's home country where the drug was actually developed, but in a tax haven-where a company's presence may be as little as a mailbox or may include legitimate manufacturing or research operations. That subsidiary then charges hefty licensing fees to subsidiaries in other countries. The fees are a tax-deductible expense in the normal jurisdictions, meaning that they can be used to offset any earnings and thereby lower the reported profits. At the same time the fee income accrues to the subsidiary in the tax haven, where it is taxed lightly or not at all. 


\section{What is a tax haven?}

There is no single and universal definition for what a tax haven is, and no universally recognized global list of tax havens. In 2016, Oxfam developed a unique and comprehensive set of indicators to identify the countries that play the greatest role as corporate tax havens, focusing on three major elements:

1. Low corporate tax rates

2. Tax incentives and harmful tax practices

3. Lack of cooperation with international efforts against tax avoidance standards

The following table lists the 15 most egregious corporate tax havens according to Oxfam's assessment in 2016:

\begin{tabular}{|l|l|l|}
\hline \multicolumn{2}{|l|}{ Top 15 corporate tax havens } \\
\hline 1. Bermuda & 6. Ireland & 11. Bahamas \\
\hline 2. Cayman Islands & 7. Luxembourg & 12. Jersey \\
\hline 3. Netherlands & 8. Curaçao & 13. Barbados \\
\hline 4. Switzerland & 9. Hong Kong & 14. Mauritius \\
\hline 5. Singapore & 10. Cyprus & 15. British Virgin Islands \\
\hline
\end{tabular}

SOURCE: Oxfam, Blacklist or Whitewash: What a Real EU List of Tax Havens Should Look Like (2017), and Berkhout, Tax Battles. In accord with this work, Oxfam has directly pressured the UK government because the UK wields official and informal influence over its Crown dependencies and overseas territories-many of which play a significant role as corporate tax havens.

Over the past five years, corporate tax dodging has generated headlines worldwide, including massive tax scandals like LuxLeaks and the Panama Papers. The resulting public pressure has forced governments and international institutions to act.

Both the EU and the G20/OECD committed to produce blacklists of tax havens. The first EU list of tax havens, called "The EU List of Non-Cooperative Jurisdictions for Tax Purposes," was released in December $2017 .{ }^{52}$

Oxfam determined that 39 countries should be considered tax havens if the EU applied its own criteria, ranging from those that advertise themselves as tax shelters (Bermuda and the Cayman Islands among others) to several jurisdictions at the heart of Europe (Ireland, Luxembourg, Malta, and the Netherlands). However, as of May 2018, only seven countries remain on the EU blacklist. More than 60 jurisdictions are "greylisted" and have committed to introduce reforms, but the EU lacks clear monitoring mechanisms to ensure compliance. ${ }^{53}$

Over recent years, governments and corporations have engaged in a cat-and-mouse game on tax dodging. As governments enact policies to protect their tax revenue, corporations' methods for shifting profits have become more elaborate, involving fictitious loans, fees for services, and sales conditions between subsidiaries of the same group.

Corporations sometimes sell their production or services not directly to the countries where they will be consumed, but to "pivot" companies in low-tax jurisdictions that then resell them at a profit to affiliated distributors. This practice creates an artificial profit that remains in the tax haven. Most of the time, these are only paper transactions-the goods are shipped straight from the factory in the production country to the warehouse in the consumption 
country-but the transactions allow profits to move from one country to another almost taxfree, or taxed at very low levels. Before agreeing to phase them out in 2020, Ireland and the Netherlands for years tailored their tax laws to welcome such "pivots," giving rise to the colorful terms "Double Irish" and "Dutch sandwich" tax planning structures. ${ }^{54}$

Further opportunities for avoiding taxes involve locating corporate brand or patents in tax havens, and fees for marketing, finance, or management services. For example, a pharmaceutical corporation may bill much of its R\&D costs on products consumed around the globe to a subsidiary in a tax haven where R\&D rights are registered, even though not a single researcher is based there. That immediately creates a cost in the country where the product is consumed, which minimizes the tax bill, and an artificial profit in the tax havens, where almost no taxes are paid in return.

As if all this weren't enough, instead of the parent firm directly owning all its subsidiaries, pharmaceutical corporations maintain a collection of holding companies: one owns shares in another that holds shares in a third. Many of these holding companies are located in tax havens and own billions of dollars of assets-yet have no employees. This strategy creates an intricate system of corporate structure where tax, legal, financial, and social accountability is dispersed across multiple jurisdictions (See Figure 5: Visualization of pharma tax structure).

Figure 5: Stylized structure of a pharma company

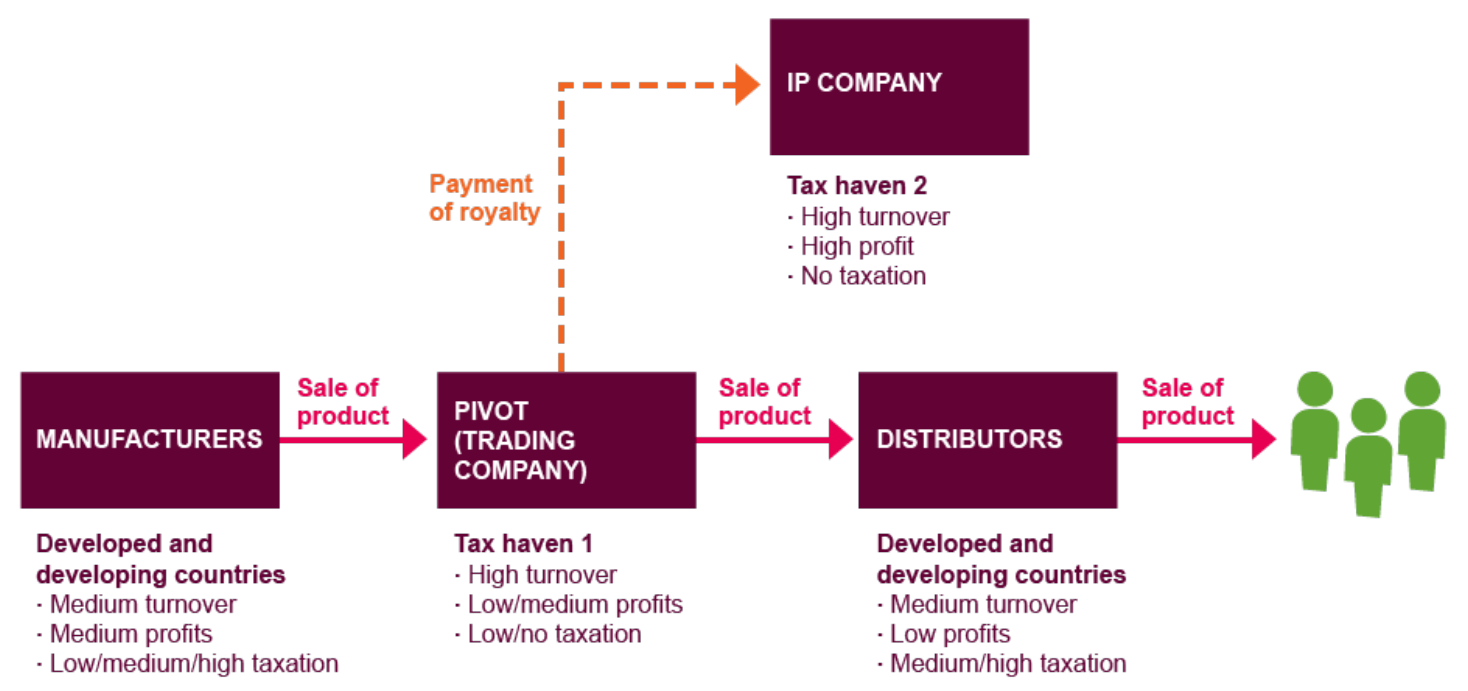

These accounting sleights of hand may well fall within the "letter of the law," although the complexity of the companies' aggressive tax avoidance strategies-and their lack of transparency-often contravene the intention of the laws themselves. The ultimate effect is that governments end up with less money to invest in the hospitals, clinics, nurses, and, yes, medicines so urgently needed by their citizens-and the yawning gap between haves and have-nots grows even wider. 


\section{A multicourse regimen of tax dodging}

Despite international reforms agreed under the OECD's Base Erosion and Profit Shifting (BEPS) project, there are still loopholes that pharmaceutical companies and other multinationals can use to avoid tax, including:

- Loans: A "finance company" established by a multinational firm in a tax haven extends a loan to a subsidiary in, say, Thailand. Often the loan is unnecessary for the day-to-day running of the company, or it is fixed in terms that exceed market conditions. The Thai company deducts the interest paid on the loan, thereby reducing taxable income in Thailand, and the profits are accounted in the tax haven where there is no tax on the interest received.

- Intangibles: An "intangibles holding company" in a tax haven acquires ownership of intellectual property (for example, the patent on a drug), and it charges royalties to subsidiaries that distribute that drug in, for example, Colombia. The royalty payments are deductible in Colombia, but there is no tax to be paid on the royalties received in a tax haven.

- Transfer pricing manipulation: The value of intangibles can also be hard to quantify, particularly when there is no external benchmark. Companies may therefore be incentivized to require subsidiaries to pay the relevant holding company in the group a higher price for using a brand or similar piece of intangible profit. This depresses the taxable profit of the subsidiary and increases the profit of the holding company, which is often based in a tax haven.

- There are other methods of profit-shifting, such as risk transfers, operating as contractors in high-tax jurisdictions to reduce profits, and exploiting mismatches between tax regimes to situate more business activity in low-tax jurisdictions. Some corporations have also been shown to benefit from "sweetheart deals" arranged directly with tax authorities. These deals include confidential tax settlements arranged between national revenue services and individual corporations that have been found to have paid insufficient taxes. Advanced pricing agreements in some countries enable corporations to pay lower rates of tax on their profits or other assets.

SOURCE: Adapted from Michael Durst, "Poverty, Tax Competition, and Base Erosion," in Taxing Multinational Businesses in Lower-Income Countries: A Problem of Economics, Politics and Ethical Norms (ICTD, 2018),

http://www.ictd.ac/publication/chapter-2-poverty-tax-competition-and-base-erosion/; and Oxfam, Making Tax Vanish: How the Practices of Consumer Goods MNC RB Show That the International Tax System Is Broken (2017),

https://oxfamilibrary.openrepository.com/bitstream/handle/10546/620289/bp-making-tax-vanish-rb-130717en.pdf?sequence $=12$.

\section{Tracking the numbers}

Oxfam began our analysis by gathering financial information from subsidiaries of four of the largest US pharmaceutical corporations. We focused on seven developing countries and four tax havens for which we could find publicly available data, plus eight advanced economies. We calculated the profit margins the four corporations enjoyed in the years 2013-2015. ${ }^{55}$ We also calculated the global average profit margins of the four corporations for those years from their filings to the US government. Then, by aggregating subsidiarylevel financial and tax information by country, we came up with an estimated tax revenue loss for those countries where we were able to obtain data by assuming an even distribution of global profits. (See this report's annex, "Tax Research Methodology," for full details.)

Pfizer, Merck, and Abbott are among the 20 US corporations with the greatest number of subsidiaries in tax havens; Johnson \& Johnson is not far behind. ${ }^{56}$ Many of the tax haven subsidiaries report unusually high profits in comparison to sales. Johnson \& Johnson's Belgian subsidiary JC General Services, for example, made more than $\$ 235$ million in profit over the three years on sales of $\$ 536.8$ million-and paid no taxes thanks to Belgium's tax incentives. That is an average profit rate of nearly 44 percent. 
Two Pfizer subsidiaries in Singapore (Pfizer Asia Pacific and Pfizer Asia Manufacturing) took in a combined $\$ 4.3$ billion in revenue in 2014 , on which they earned a profit of $\$ 2.1$ billion-a rate of more than 49 percent. As their names indicate, these two subsidiaries may sell their wares to other subsidiaries in Asia, while keeping most of the profit in low-tax Singapore. How much of the revenue results from Singapore-based manufacturing and R\&D and how much revenue is from intermediary trade among Pfizer subsidiaries is impossible to discern.

As noted above, the companies' profit margins tend to be in inverse proportion to the applicable tax rate in each country: where rates are standard, profits are low; where rates are abnormally low, profits are abnormally high.

The analysis done by Oxfam does not prove that the companies are engaged in profitshifting that crosses the line of what is allowed under existing rules. Only tax authorities with access to their full tax returns can determine whether some transactions are unlawful.

While the information available publicly is far from complete, the pattern is consistent: subsidiaries located in tax havens are on average significantly more profitable than those located elsewhere. That is not what one would expect if the geographic distribution of profits reflected the geographic distribution of the real value of economic activities.

\section{Impact on developing countries}

US pharmaceutical companies make a lot of money selling medicine in developing countries, most of it in middle-income countries. For 2015, 42 percent of Abbott's sales were made in "emerging markets"; for Johnson \& Johnson that figure was 26 percent; for Pfizer, 23 percent; and for Merck 17 percent was from Asia (excluding Japan) and Latin America. ${ }^{57}$ Yet the companies' tax practices may result in significant revenue losses to many developing countries.

In the seven developing countries alone, the four corporations may have paid an additional $\$ 112$ million in taxes annually had their profits been more evenly distributed. This amounts to more than half of the $\$ 195$ million they did pay, which put another way means they may have underpaid one-third of the tax they truly owe. Johnson \& Johnson may have underpaid by $\$ 55$ million in taxes every year, Pfizer may have underpaid by $\$ 22$ million, Abbott by $\$ 30$ million, and Merck by $\$ 5$ million. The following table breaks down that data by country. ${ }^{58}$

Figure 2: Estimated annual tax underpayment in developing countries

\begin{tabular}{|l|c|c|c|c|r|}
\hline & Abbott & J\&J & Merck & \multicolumn{1}{c|}{ Pfizer } & \multicolumn{1}{c|}{ TOTAL } \\
\hline Chile & $\$ 4,651,266$ & - & - & - & $\$ \mathbf{\$ 4 , 6 5 1 , 2 6 6}$ \\
\hline Colombia & $\$(1,952,883)$ & $\$ 1,088,770$ & $\$ 1,228,112$ & $\$ 11,506,827$ & $\mathbf{\$ 1 1 , 8 7 0 , 8 2 6}$ \\
\hline Ecuador & $\$ 2,168,863$ & - & $\$ 472,655$ & $\$ 2,058,569$ & $\mathbf{\$ 4 , 7 0 0 , 0 8 7}$ \\
\hline India & $\$ 30,171,485$ & $\$ 41,450,191$ & $\$ 2,296,686$ & $\$(137,778)$ & $\mathbf{\$ 1 3 , 7 8 0 , 5 8 4}$ \\
\hline Pakistan & - & - & - & $\$ 1,654,868$ & $\mathbf{\$ 1 , 6 5 4 , 8 6 8}$ \\
\hline Peru & $\$(5,191,248)$ & $\$ 1,920,555$ & $\$(1,580,927)$ & $\$ 1,884,431$ & $\mathbf{\$ ( 2 , 9 6 7 , 1 8 8 )}$ \\
\hline Thailand & $\$ 632,044$ & $\$ 10,174,664$ & $\$ 3,049,057$ & $\$ 4,799,166$ & $\mathbf{\$ 1 8 , 6 5 4 , 9 3 2}$ \\
\hline
\end{tabular}




\begin{tabular}{|l|c|c|c|c|c|}
\hline & Abbott & J\&J & Merck & Pfizer & TOTAL \\
\hline $\begin{array}{l}\text { Developing } \\
\text { countries }\end{array}$ & $\mathbf{\$ 3 0 , 4 7 9 , 5 2 7}$ & $\mathbf{\$ 5 4 , 6 3 4 , 1 8 0}$ & $\mathbf{\$ 5 , 4 6 5 , 5 8 4}$ & $\mathbf{\$ 2 1 , 7 6 6 , 0 8 3}$ & $\mathbf{\$ 1 1 2 , 3 4 5 , 3 7 4}$ \\
\hline $\begin{array}{l}\text { Note: Numbers in parentheses are negative; they indicate where the national-level profit } \\
\text { margin was higher than the global average profit margin. Entries without a number } \\
\text { indicate that no country-level financial information was available. }\end{array}$ \\
\hline
\end{tabular}

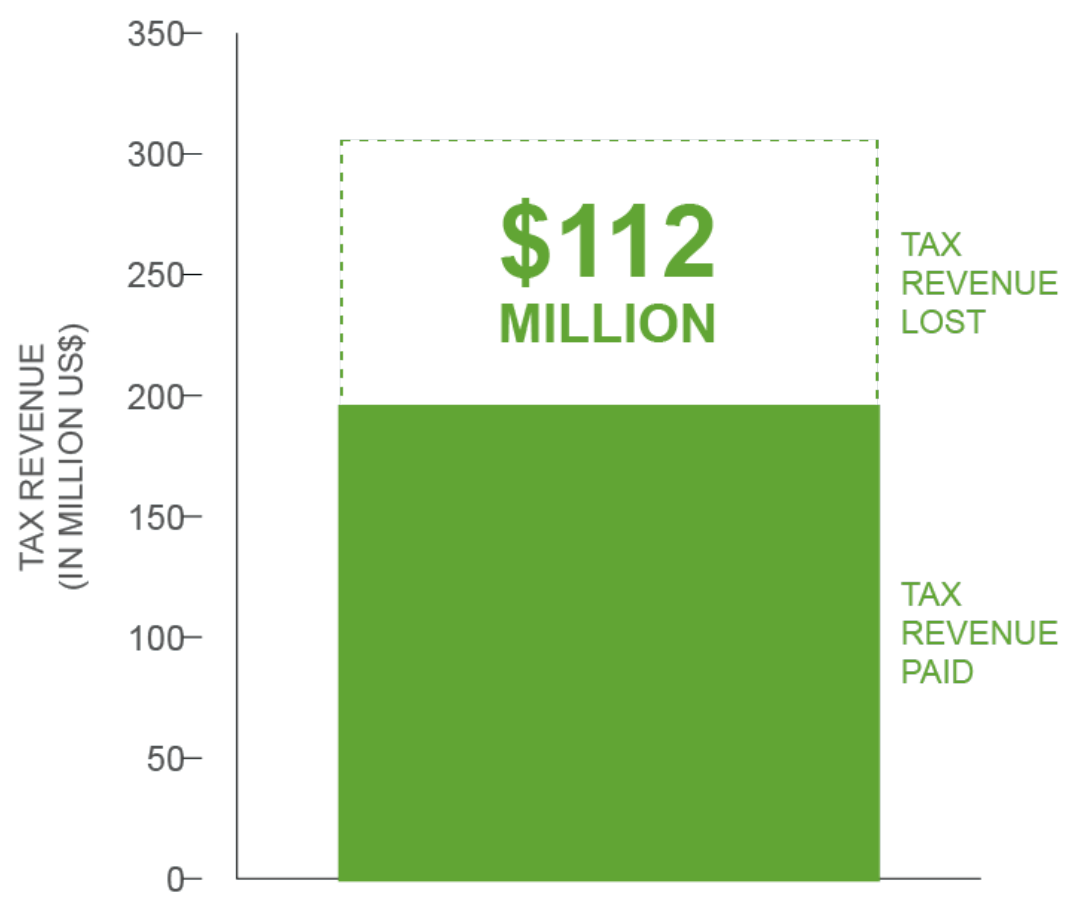

SOURCE: Oxfam analysis of national-level financial filings from four drug companies from 2013 to 2015. Estimated tax underpayment represents the difference between the taxes these companies would pay under a system that apportions global profits equally across countries and the taxes these companies report they actually paid. For more information, please see this report's "Tax Research Methodology" annex.

These estimates are necessarily inexact, calculated by holding the global average profit margin consistent across every country in which pharma companies operate, and by using overall sales as a proxy for economic activity. This calculation is obviously a rough proxy; there are many reasons why profit margins vary across countries. Other proxies for overall economic activity could include employee data or physical or intangible assets-but drug companies do not consistently make this information public, illustrating the pressing need for more transparency by large corporations on where they do their actual business and where they declare profits.

Oxfam's estimates of tax underpayment are pocket change to these corporate giants. But they represent significant losses to low-income and middle-income countries. Developing countries could use the money to address the yawning gaps in public health services that keep many of the poorest people in the world from lifting themselves out of poverty. 
The HPV vaccine is one example. Human papilloma virus (HPV) is a sexually transmitted infection. ${ }^{59} \mathrm{HPV}$ can cause cervical cancer, the fourth-most-common cancer among women worldwide and the second-most-common cancer in women living in less developed regions. ${ }^{60}$ HPV kills 300,000 people every year ${ }^{61}$ Currently, every two minutes a life is lost to this disease, and nine of 10 of these deaths are women in low- and middle-income countries. ${ }^{62}$ In India, 67,477 women died of cervical cancer in $2012 .{ }^{63}$ The HPV vaccine drastically reduces the incidences of HPV and cervical cancer. ${ }^{64}$

The amount of money we estimate these companies may have underpaid in taxes would be enough to buy vaccines for more than 10 million girls, about two-thirds of the girls born in these seven countries in $2016 .{ }^{65}$ India could buy HPV vaccines for 8.1 million girls, which is 65 percent of the girls born in 2016 . $^{66}$ In Thailand, where 4,500 women die each year from cervical cancer, the $\$ 18.65$ million in taxes we estimate these companies dodged per year would be enough to pay for HPV vaccines for more than 775,000 girls, more than double the number born in $2016 .{ }^{67}$

Another example of the effects of these companies' avoidance of paying fair taxes is pneumonia, which kills one million children worldwide each year and is the leading cause of mortality in children under $5 .{ }^{68}$ An estimated 408,000 children will die from pneumonia in India each year, and another 91,000 will die in Pakistan. ${ }^{69}$ But the pneumonia vaccine can have a substantial impact in reducing these deaths. ${ }^{70}$ With the estimated missing tax money, India could buy vaccines for 8.3 million children, almost one-third of the children born in 2016. Thailand could buy vaccines for 90,000 children, or 13 percent of the children born in 2016. ${ }^{71}$ In total, the seven developing countries we looked at (Chile, Colombia, Ecuador, India, Pakistan, Peru, and Thailand) could buy pneumonia vaccines for 8.9 million children with the estimated missing tax money (see Figure 6: Pneumonia vaccines in Thailand).

\section{Figure 6: Pneumonia vaccines in Thailand}

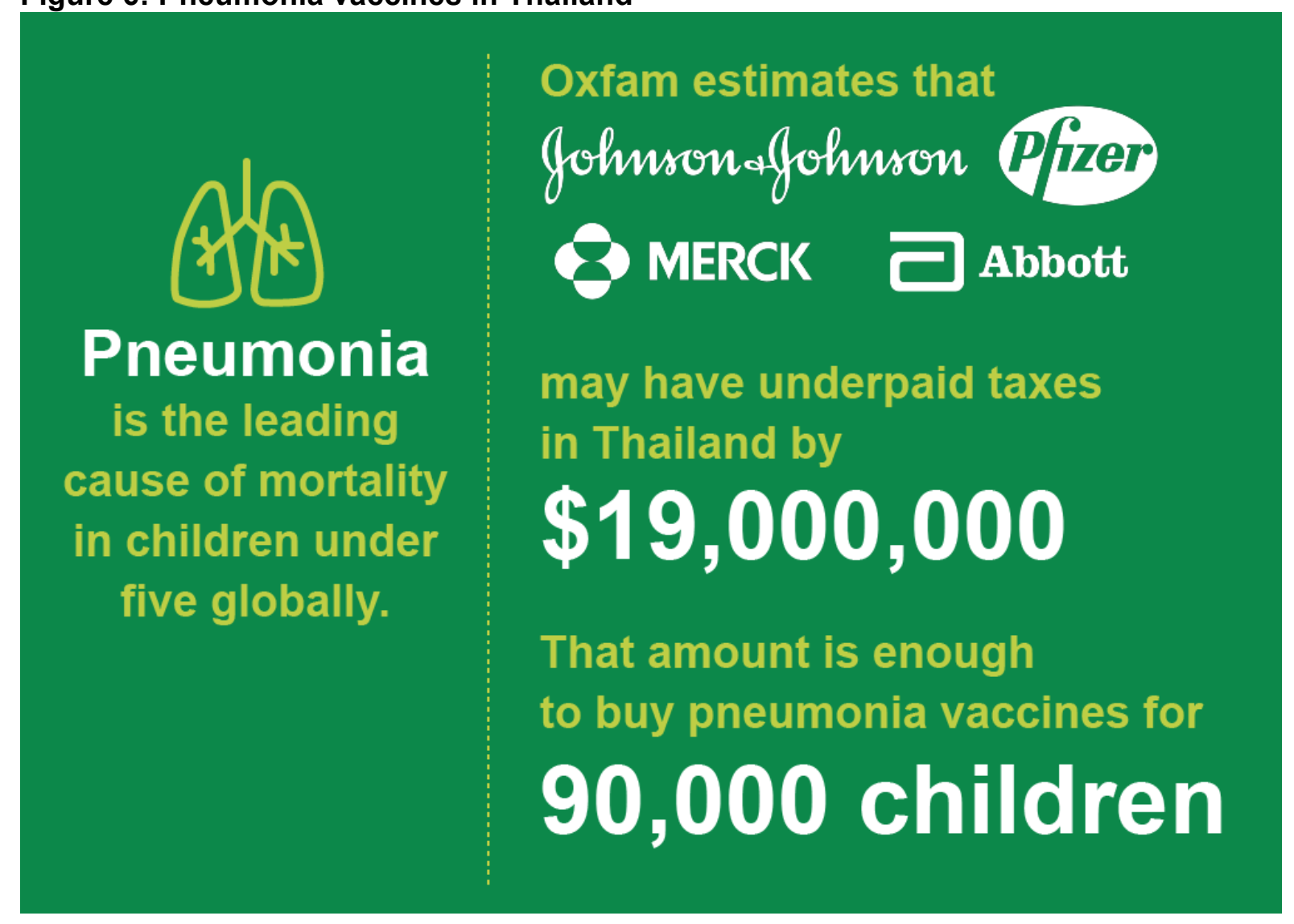


According to a recent study, tax revenue is a major determinant of progress towards universal health coverage in low and middle-income countries. ${ }^{72}$ Lack of government spending, meanwhile, yields worse health outcomes, including higher mortality rates. ${ }^{73}$

\section{The human costs of tax avoidance: Gorakhpur, India}

The tragedy at Baba Raghav Das Memorial Medical College and Hospital (BRD)—where 69 children died in just four days in 2017-offered a rare global spotlight on the long-simmering crisis facing India's public health services. India spends a paltry 1.4 percent of its GDP on health care compared with the world average of 6 percent.

Indian's underinvestment is fueled, in part, by extreme pressure placed on India's public revenues by corporations evading and avoiding their taxes.

A leading cause of death in some districts of India is Japanese encephalitis, a mosquitoborne disease most often contracted because of poor sanitation, proximity to livestock, and lack of preventive public health services. BRD hospital is the only facility that can handle serious cases of Japanese encephalitis in the Gorakhpur district, which has a population of more than 4.4 million and stretches over 1,200 square miles. ${ }^{74}$

Golu is an 8-year-old boy from the village of Manbela, just over a mile from BRD. His brain and body are stunted because he contracted Japanese encephalitis when he was 4 .

"Earlier he could talk, he used to call me 'sister,"' says his sister Preeti. Now, she says, "He cannot talk, he cannot eat on his own, and he cannot walk." Their village does not have access to drinking water. Many children go unvaccinated and sleep without protection from mosquitoes.

The underlying problem, hospital officials told Oxfam, is the absence of primary health care and sanitation facilities in rural areas. Measures to prevent the spread of the disease are inadequate, and once children contract it, they are only brought to BRD when they are about to die.

"The whole Gorakhpur tragedy to me is really just because there is just one BRD hospital and there is a huge vacuum down below," says K. Sujatha Rao, former health secretary of India.

In February 2016, the principal of BRD hospital wrote to the director general of Medical and Health Services of Uttar Pradesh seeking $\$ 5.5$ million for the treatment of encephalitis cases. ${ }^{75}$ Neither the federal nor state governments managed to provide the money.

Pharma corporations are not responsible for the tragedy at Gorakhpur. The Indian government must do much more to invest in the health of its citizens. Nonetheless, stopping corporate tax dodging is critical to ensuring governments have the necessary resources to invest in their citizens. Had the Indian government received the estimated $\$ 74$ million the four US drug companies may have underpaid in taxes annually, it could have allocated these funds to fighting encephalitis and still have had enough money left to buy Japanese encephalitis vaccines and bed nets for every child born each year in the whole of India (see Figure 7: Encephalitis vaccines in India). 
Oxfam estimates that

\section{Gohnsonafohnson Pfizer 8 MERCK $\rightleftharpoons$ Abbott}

may have underpaid taxes in India by

$\$ 74,000,000$

which could buy

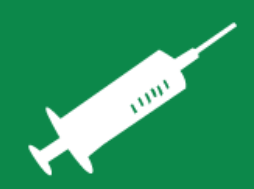

Japanese

Encephalitis

vaccines

8

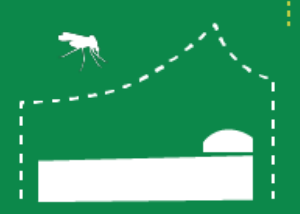

bed nets

\section{for every child born in the whole of India in one year}

\section{Women pay the price}

Corporate tax dodging reduces the funds available to invest in public services that give people the means to better their lot. This outcome is especially the case for girls and women, who are more likely to live in poverty-and who are more likely to rely on publicly funded health care and less likely to be able to pay out-of-pocket for health care. ${ }^{76}$

When public services are inadequate or unavailable, women step in as caregivers, often compromising their health and their opportunities for education and employment. A study estimated women's unpaid health work at 2.35 percent of global GDP, half of the $\$ 3$ trillion that women contribute to health care, paid and unpaid. ${ }^{77}$

Conversely, quality public systems increase women's economic opportunities and their decision-making power within the household.

Besides draining money from social services, tax dodging worsens the suffering caused by the implicit and explicit gender biases in tax systems, because it requires governments to raise a greater proportion of their revenue from other sources. Most developing countries raise two-thirds or more of their tax revenue through consumption taxes, which eat up a larger proportion of income the poorer you are. And women are more likely to be poor than men.

Corporate tax dodging widens the inequality gap between men and women in yet another way: the money the companies fail to pay in taxes gets funneled to shareholders and senior executives, who are overwhelmingly male (see Figure 8: Fiscal justice is gender justice). 
Figure 8: Fiscal justice is gender justice

\section{Tax dodging widens the inequality gap between men and women}

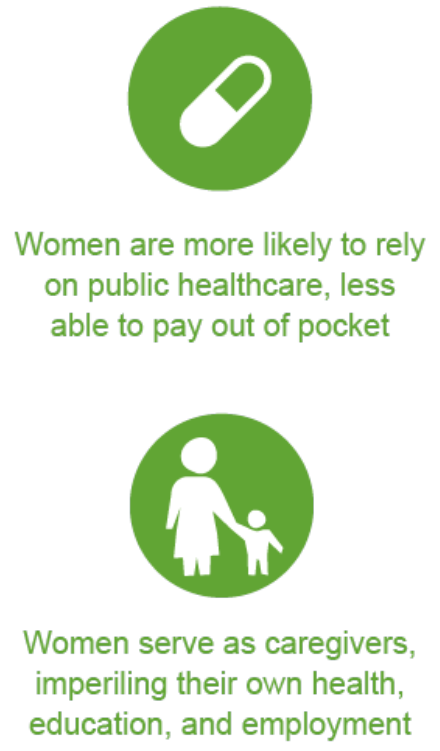

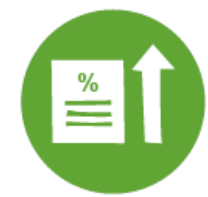

Cash-starved governments often increase consumption taxes-which fall hardest on women

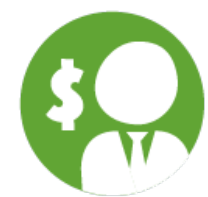

Corporate profits go to wealthy shareholders and senior company executives-who are overwhelmingly male

\section{Impact on wealthy countries}

In advanced economies, the companies appear to avoid proportionally even more in taxes than in developing countries, an estimated total of nearly $\$ 3.7$ billion annually-two-thirds of the $\$ 5$ billion they actually pay. Johnson \& Johnson led the pack with an estimated $\$ 1.7$ billion underpaid. Pfizer may have underpaid $\$ 1.1$ billion, Merck $\$ 739$ million, and Abbott $\$ 169$ million. $^{78}$ The table below breaks down the data by country.

Figure 4: Estimated annual tax underpayment in advanced economies

\begin{tabular}{|l|r|r|r|r|r|}
\hline & \multicolumn{1}{|c|}{ Abbott } & \multicolumn{1}{c|}{ J\&J } & \multicolumn{1}{c|}{ Merck } & \multicolumn{1}{c|}{ Pfizer } & \multicolumn{1}{c|}{ Total } \\
\hline Australia & $\$ 5,548,716$ & $\$ 70,987,178$ & $\$ 16,616,610$ & $\$ 72,054,671$ & $\mathbf{\$ 1 6 5 , 2 0 7 , 1 7 6}$ \\
\hline Denmark & $\$ 122,685$ & $\$ 5,578,635$ & $\$ 2,591,097$ & $\$ 13,265,165$ & $\$ \mathbf{\$ 2 1 , 5 5 7 , 5 8 1}$ \\
\hline France & $\$ 13,018,931$ & $\$ 197,518,429$ & $\$ 51,084,419$ & $\$ 157,117,977$ & $\mathbf{\$ 4 0 9 , 4 3 4 , 1 7 9}$ \\
\hline Germany & $\$ 5,123,061$ & $\$ 159,095,358$ & $\$ 52,651,783$ & $\$ 99,845,535$ & $\mathbf{\$ 3 1 6 , 7 1 5 , 7 3 7}$ \\
\hline Italy & $\$ 14,083,238$ & $\$ 94,977,531$ & $\$ 25,229,356$ & $\$ 133,662,556$ & $\mathbf{\$ 2 6 7 , 9 5 2 , 6 8 1}$ \\
\hline New & $\$ 1,008,107$ & $\$ 7,210,106$ & $\$ 2,090,100$ & $\$ 3,546,806$ & $\$ \mathbf{\$ 1 3 , 8 5 5 , 1 1 9}$ \\
\hline Zealand & $\$(7,126,288)$ & $\$ 58,868,644$ & $\$ 32,629,391$ & $\$(92,081,397)$ & $\mathbf{\$ ( 7 , 7 0 9 , 6 4 9 ) )}$ \\
\hline Spain & $\$(5,541,997)$ & $\$ 96,566,015$ & $\$ 22,977,313$ & $\$ 80,969,794$ & $\mathbf{\$ 1 9 4 , 9 7 1 , 1 2 5}$ \\
\hline UK & & & & & \\
\hline
\end{tabular}




\begin{tabular}{|l|c|c|c|c|c|}
\hline & Abbott & J\&J & Merck & Pfizer & Total \\
\hline USA $^{*}$ & $\$ 143,000,000$ & $\$ 1,046,000,000$ & $\$ 533,000,000$ & $\$ 589,000,000$ & $\mathbf{\$ 2 , 3 1 1 , 0 0 0 , 0 0 0}$ \\
\hline TOTAL & $\mathbf{\$ 1 6 8 , 7 5 8 , 4 5 2}$ & $\mathbf{\$ 1 , 7 3 7 , 0 8 8 , 3 9 6}$ & $\mathbf{\$ 7 3 8 , 9 8 8 , 8 1 9}$ & $\mathbf{\$ 1 , 0 5 7 , 3 8 4 , 2 7 4}$ & $\mathbf{\$ 3 , 7 0 2 , 2 1 9 , 9 4 2}$ \\
& $\begin{array}{l}\text { Note: Numbers in parentheses are negative; they indicate where the national-level } \\
\text { profit margin was higher than the global average profit margin. }\end{array}$ \\
\hline & $\begin{array}{l}\text { * The numbers for the United States were calculated using a slightly different } \\
\text { methodology because the companies do report consolidated financial information } \\
\text { for the US, but not other countries. See this report's "Tax Research Methodology" } \\
\text { annex for details. }\end{array}$ \\
\hline
\end{tabular}

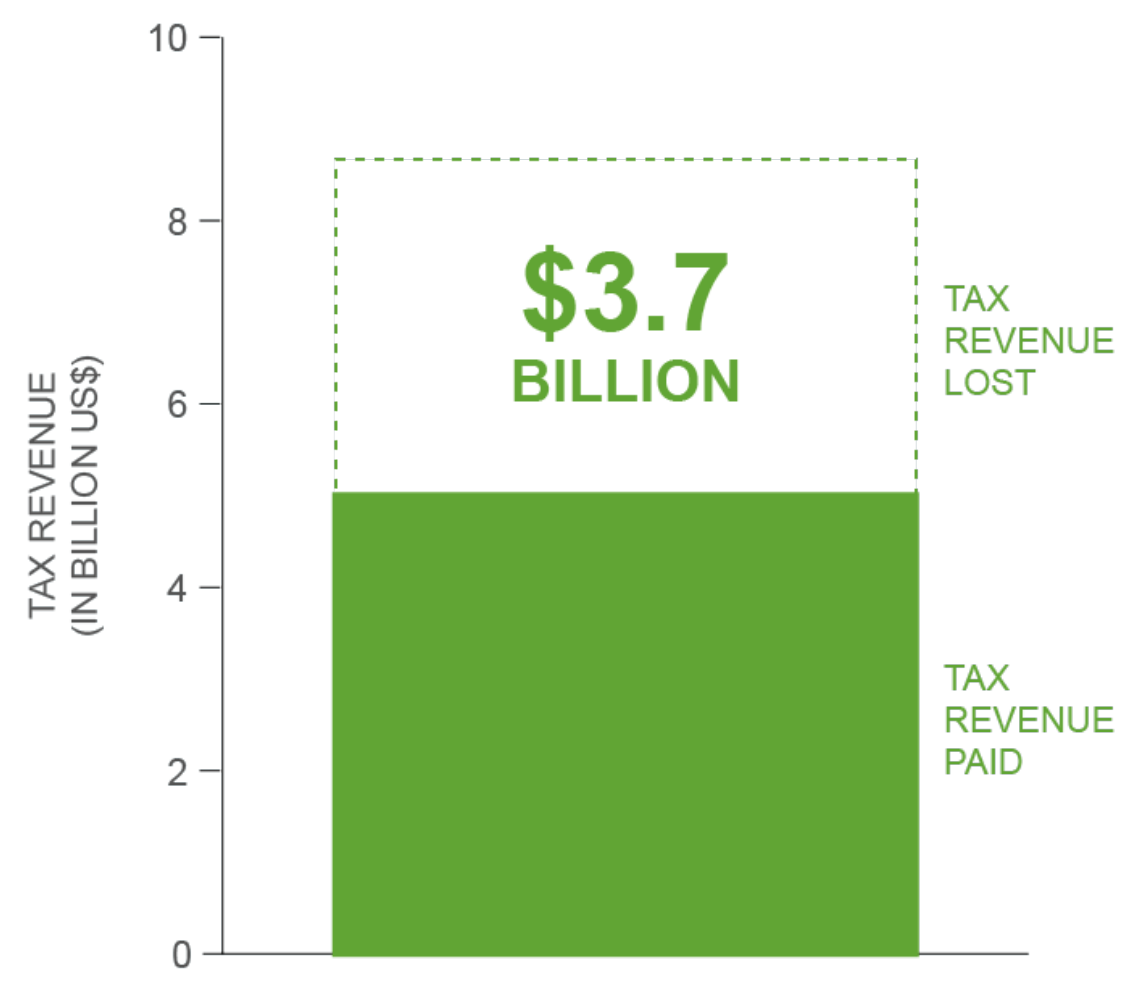

SOURCE: Oxfam analysis of national-level financial filings from four drug companies from 2013 to 2015 . Estimated tax underpayment represents the difference between the taxes these companies would pay under a system that apportions global profits equally across countries and the taxes these companies report they actually paid. For more information, please see this report's "Tax Research Methodology" annex.

As the largest market for the four pharmaceutical companies, the United States is the biggest loser from these companies' tax avoidance, to the tune of an estimated $\$ 2.3$ billion a year: $\$ 1$ billion by Johnson \& Johnson, $\$ 589$ million by Pfizer, $\$ 533$ million by Merck, and $\$ 143$ million by Abbott. ${ }^{79}$ This is enough to pay for health insurance for nearly a million poor children in the $\mathrm{US}^{80}$ (See Figure 9: The tradeoffs of tax dodging-healthcare for low-income kids). 
Figure 9: The tradeoffs of tax dodging-healthcare for low-income kids

Oxfam estimates that

Gohnsonafohuson Pfizer \& MERCK E Abbott

dodge an average of

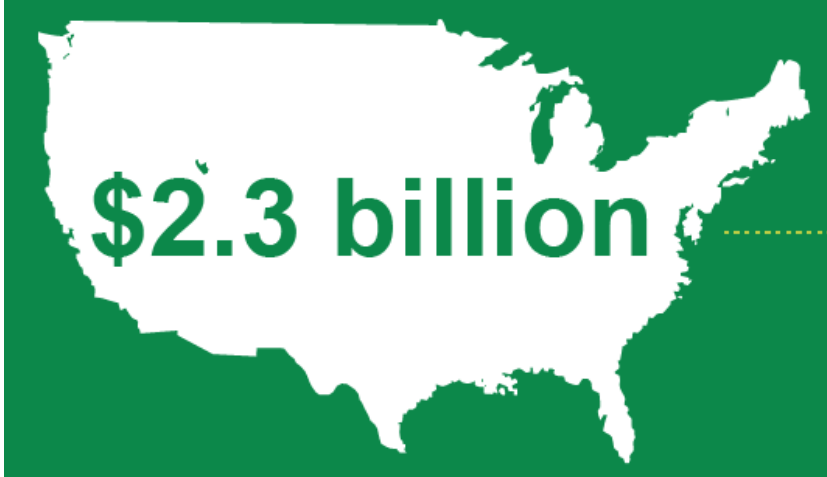

in taxes per year in the US. $\rightarrow$ This amount is

enough for the

US government

to provide health

insurance for nearly

$1,000,000$

uninsured kids

in the US.

The companies' declared profit margins on operations in the United States are consistently lower than on international operations. Pfizer posted losses on US operations of 8 percent in 2013, 25 percent in 2014, and 31 percent in 2015. The pattern has continued, with Pfizer posting losses of 32 percent in 2016 and 26 percent in 2017. Meanwhile, Pfizer's

international operations earned 56-58 percent in 2013-2015 and even more in the two years since (64 and 72 percent). The story is similar though less extreme for Abbott and Johnson \& Johnson. ${ }^{81}$

Before the US tax reform of 2017, a particular problem for the United States was the earnings companies stockpiled overseas. Because US taxes on overseas profits only came due when they were "repatriated," i.e., paid out as dividends to the parent company in the United States, corporations kept vast sums offshore. This peculiarity of US tax law explains how Pfizer managed to report no taxable income on its domestic operations every year between 2007 and 2016, despite worldwide profits of $\$ 110$ billion. $^{82}$

By the end of 2017 , US Fortune 500 companies were holding almost $\$ 2.6$ trillion in untaxed earnings offshore ${ }^{83} \mathrm{~A}$ year earlier, the portion held by the four largest US pharmaceutical companies was $\$ 352$ billion. ${ }^{84}$ Pfizer's $\$ 199$ billion held offshore was the second most of any US corporation. ${ }^{85}$

Stuck with offshore earnings accumulating year after year, pharma companies lobbied for ways to get around paying the tax upon repatriation. In 2004, hoping the companies would invest the funds to create jobs in the United States, the administration of George W. Bush declared a "tax holiday": for a limited time, repatriated offshore earnings would be taxed at 
only 5.25 percent (instead of 35 percent). Pharmaceutical companies took advantage of Uncle Sam's generosity, with Pfizer repatriating $\$ 37$ billion, the most of any company. ${ }^{86}$ Rather than invest in job creation, the repatriated profits wound up in the pockets of shareholders and executives. Pfizer cut 10,000 jobs between 2005 and 2006; Merck repatriated $\$ 16$ billion and slashed 7,000 jobs over the same period. ${ }^{87}$ Between 2003 and 2012, the biggest US corporations spent more than 90 percent of their profits in stock buybacks and dividends-a topic we will return to in Chapter $3 .^{88}$

If the US were not losing enough corporate tax revenue already, the new Tax Cuts and Jobs Act approved in December 2017 dug the hole deeper. ${ }^{89}$ Not only does it lower the corporate tax rate from 35 percent to 21 percent, it allows companies to repatriate their offshore cash for a one-off 15.5 per cent levy-and even lower for some types of holdings. ${ }^{90}$ The Financial Times estimates that US corporations will save up to $\$ 500$ billion over what they would have owed had they not stashed their profits overseas. ${ }^{91}$

What the corporations save, the US public loses. Estimates of the one-time tax losses to the US public from three of the four drug companies total almost $\$ 50$ billion, with recurring annual losses of nearly $\$ 4$ billion. The following table details the estimated losses to the US public because of US tax reform's impact on these companies alone. ${ }^{92}$

Figure 10: Drug company benefits from Trump tax bill

\begin{tabular}{|l|c|c|c|c|c|}
\hline \multicolumn{1}{|c|}{ Company } & $\begin{array}{c}2018 \\
\text { estimated } \\
\text { annual tax } \\
\text { cut }\end{array}$ & $\begin{array}{c}\text { One-time } \\
\text { tax cut on } \\
\text { offshore } \\
\text { profits }\end{array}$ & $\begin{array}{c}\text { Stock } \\
\text { buybacks } \\
\text { announced } \\
\text { since } 2017 \text { tax } \\
\text { reform }\end{array}$ & $\begin{array}{c}\text { 2018 } \\
\text { stated or } \\
\text { estimated } \\
\text { cost of } \\
\text { promised } \\
\text { bonuses }\end{array}$ & $\begin{array}{c}\text { CEO-to- } \\
\text { worker } \\
\text { pay ratio }\end{array}$ \\
\hline $\begin{array}{l}\text { Johnson \& } \\
\text { Johnson }\end{array}$ & No estimate & $\$ 9$ billion & $\begin{array}{c}\text { None } \\
\text { announced }\end{array}$ & $\$ 0$ & 452-to-1 \\
\hline Merck & $\$ 2.8$ billion & $\$ 13$ billion & $\$ 10$ billion & $\$ 69$ million & 215-to-1 \\
\hline Pfizer & $\$ 1$ billion & $\$ 25.5$ billion & $\$ 10$ billion & $\begin{array}{c}\$ 100 \\
\text { million }\end{array}$ & 313-to-1 \\
\hline
\end{tabular}

SOURCE: Adapted from Americans for Tax Fairness, Bad Medicine: How GOP Tax Cuts Are Enriching Drug Companies, Leaving Workers and Patients Behind (2018), available at https://americansfortaxfairness.org/pharma-leaving-workerspatients-behind/.

The Tax Cuts and Jobs Act ends the deferral of tax on offshore profits until repatriation, and it contains new provisions intended to fight aggressive tax planning. However, these provisions are ill-designed and also open new avenues for profit-shifting. ${ }^{93}$ The bottom line is that the Tax Cuts and Jobs Act creates a lower tax rate for profits earned overseas, which can incentivize US corporations to increase offshoring of both profits and jobs.

\section{Legal options}

Tax authorities have legal options to challenge profit-shifting by corporations. However, the complexity of the companies' tax avoidance strategies, coupled with their lack of transparency, complicates matters, especially in developing countries. Tax authorities are underresourced, courts are slow, and fines tend to be low. Most authorities prefer to settle out of court, which may well suit the corporations, as such settlements keep the details of their misdeeds from being aired in public, and, most importantly, stymie building a clear body of case law for the future. (See "Bribery, Kickbacks, and Other Crimes" in Chapter 3.) 
Equally problematic is that many developing countries have subscribed to the theory that tax concessions are necessary to attract much-needed foreign investment, a doctrine promoted by a powerful army of corporate tax lawyers. As a consequence, countries have tried to outdo their neighbors in cutting corporate tax rates and offering a variety of tax incentives. ${ }^{94}$ Tax havens are front-runners in this global race to the bottom. Yet nearly every country, rich and poor, today abets companies in their desire to avoid taxes. Kenya loses $\$ 1.1$ billion a year to tax exemptions and incentives-almost twice what the government spends on its entire health budget, in a country where mothers face a one in 40 chance of dying in childbirth. ${ }^{95}$ Nigeria loses $\$ 2.9$ billion, twice as much as it spends on education, despite six million girls in the country not attending school. ${ }^{96}$

One tax incentive in the Netherlands-the "innovation box," a favorite of the pharmaceutical companies-cost the country well over 1.2 billion euros in 2016 (7.6 percent of the Netherlands' total income from corporate taxes).$^{97}$ In 2017, the tax losses increased to 1.7 billion euros. ${ }^{98}$ Despite the overall negative evaluations about the effectiveness of "patent boxes" in general, and the Dutch innovation box specifically, the Dutch government has refused to change its policy, mainly because the government sees it as a tool in its corporate tax competition with other countries. Similar structures in the UK, the patent box and R\&D tax relief, cost the Exchequer $£ 3.5$ billion in $2016 .{ }^{99}$

Governments bear responsibility for rampant tax avoidance and must work together to put an end to destructive competition on corporate tax. But corporations are by no means innocent. They manipulate the system to their own tax advantage, while at the same time using the mobility of their capital to obtain tax concessions from countries that desperately need foreign investment. Corporations must begin to choose the high road on responsible corporate behavior.

Let us now turn to how the companies managed to win the favorable rules and regulations that permit them to raise prices at will and avoid paying taxes. 


\section{Chapter 2: Drug companies own the swamp}

Ten days before taking office in 2017, President Donald Trump lambasted the country's major drug producers. "Pharmaceutical companies are getting away with murder," he said, and he called for new procurement procedures for the public Medicare program to bring down the inordinately high price of prescription medicines. ${ }^{100}$

The main drug industry trade association, Pharmaceutical Researchers and Manufacturers of America (PhRMA), immediately launched a multimillion-dollar TV ad campaign touting the companies' scientific breakthroughs. ${ }^{101}$ Ten days after Trump's inauguration, ahead of a closed-door meeting with PhRMA and six CEOs, Trump did an about-face: from first pushing the companies to lower prices, he promised to make other countries pay more for medicines and to prioritize "lowering taxes big league."102

The companies regularly air ad campaigns to enhance their image, but only on occasion do they have to resort to meeting with the president of the United States. Well aware that their profits depend on favorable government regulation and tax treatment-along with public procurement, drug certification, protection of intellectual property, and hefty government investment in medical research-the companies maintain a plethora of ongoing relationships with politicians and officials.

This story illustrates the pernicious nexus of economic and political inequality-drug companies use their profits to buy political access, and they use that access to rig the rules to protect their profits. Wealthy shareholders and executives win "big league"- the rest of us lose out.

Year after year the pharmaceutical industry spends the most of any industry lobbying the US government, more than $\$ 200$ million annually. ${ }^{103}$ Industry representatives lobby federal agencies, both houses of Congress, and the White House to ensure and extend pharmaceutical companies' monopoly control of drugs and to facilitate the maneuvers by which they can set and raise prices at will and hide profits in overseas tax havens. They also lobby very effectively to encourage US officials to lean on policymakers and regulators in developing countries, winning beneficial treatment often at the expense of citizens and their health.

The companies and their trade associations deploy a small army of professional lobbyists and make significant campaign contributions to candidates for office from both political parties. And they have proven themselves adept at placing their own senior executives and lobbyists in high government positions. This chapter will examine the three main avenues the companies use to play the Washington political game-lobbying, making campaign contributions, and capturing government posts-beginning with the last, because it has become so notorious under President Trump (see Figure 11: Swamp creatures). 


\section{Figure 11: Swamp creatures}

\section{The pharmaceutical industry spends the most of any industry lobbying the US government-more than $\$ 200$ million annually}

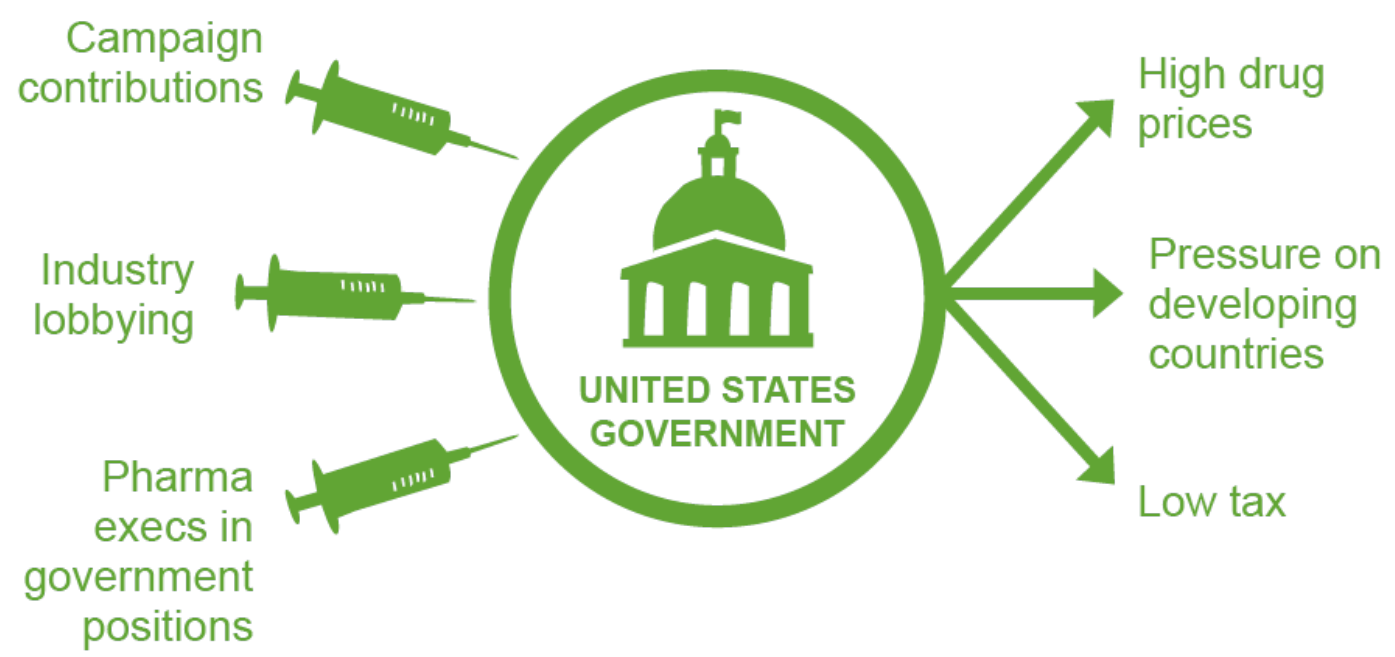

\section{Corporate capture}

Soon after the president's about-face on the high cost of medicine, the White House formed a Drug Pricing and Innovation Working Group led by Joe Grogan, Trump's appointee to the Office of Management and Budget. Barely weeks earlier, Grogan had been the lead lobbyist for Gilead, a major pharmaceutical company. The working group, according to leaked documents, was made up of drug company executives and would seek ways, not to bring down prices, but to extend the patent life of drugs in foreign markets. ${ }^{104}$

Of the many high-level appointees Trump imported from corporate America, two must be particularly cherished by the pharmaceutical industry: Scott Gottlieb and Alex Azar. Gottlieb, the man chosen to lead the Food and Drug Administration-which evaluates and approves new medicines-previously served as director of eight pharmaceutical companies and one laboratory company. ${ }^{105} \mathrm{He}$ was handsomely paid for speeches to several drug companies, including Merck and Johnson \& Johnson. ${ }^{106}$

The other top post of interest is the secretary of Health and Human Services, a Cabinet-level post that oversees government health care policy. Trump first selected Congressman Tom Price, a Georgia Republican and former surgeon, who claimed to have entered politics in order to dismantle government regulation of health care. As a congressman, in the spring of 2016 he proved his worth to the pharmaceutical companies by arranging to scuttle a proposed rule that would have removed doctors' incentive to prescribe expensive drugs. After barely six months in the cabinet, however, Price was forced to resign after accusations of insider trading and profligate spending of taxpayer dollars to fly on private jets and military aircraft. ${ }^{107}$ Trump replaced him, not with another pharma-friendly lawmaker, but with an actual pharmaceutical executive, Alex Azar, president of Eli Lilly USA, the largest division of Eli Lilly and Company between 2012 and 2017.

Another adviser of note is Tomas Philipson, who sits on the Council of Economic Advisors. A University of Chicago economist, Philipson co-founded a consultancy that works for major 
drug companies. ${ }^{108}$ And the White House liaison at the Department of Health and Human Services, Timothy Clark, is the former president of a lobbying firm that has represented pharmaceutical companies. ${ }^{109}$

As far as impact on developing countries is concerned, the crucial position is the US trade representative, whose mandate includes pressuring countries whose policies the United States believes hinder drug company profits. The pharmaceutical corporations have their man: Robert Lighthizer, an international trade lawyer who served as deputy trade representative under President Ronald Reagan and most recently worked at the law firm representing Pfizer, Merck, and Abbott, among others, on international tax issues and mergers and acquisitions. ${ }^{110}$

\section{Lobbying}

What the corporations are unable to secure through appointees, they try to get through lobbying. One of the saddest and most egregious episodes of drug company lobbying occurred two years ago, when Congress voted to strip the Drug Enforcement Administration of its most potent weapon to fight the spread of opioid addiction, which had already claimed 200,000 lives in the United States.

In 2014 the DEA began aggressively interdicting shipments of prescription opioids that the DEA suspected were supplying corrupt doctors and pharmacists who peddled narcotics to the black market, fueling demand among addicts. When officials rebuffed the manufacturers' demand that they back off, the companies turned to Congress. A two-year lobbying campaign culminated in a 2016 vote to rescind the DEA's legal authority to block those drug shipments. ${ }^{111}$

The pharmaceutical industry has the largest network of people working for a special interest in the United States: nearly 1,500 agents of professional lobby firms in 2017 , equivalent to 13 percent of all lobbyists. ${ }^{112}$ Most of this workforce is made up of former members of Congress and former high-ranking federal employees, who use their government experience and connections to advocate more effectively. Sixty-four percent of pharmaceutical lobbyists in 2017 were such "revolvers"-in reference to the "revolving door" between business and government that lies at the heart of Washington's malaise. ${ }^{113}$ 
Figure 12: PhRMA lobbyists and revolvers

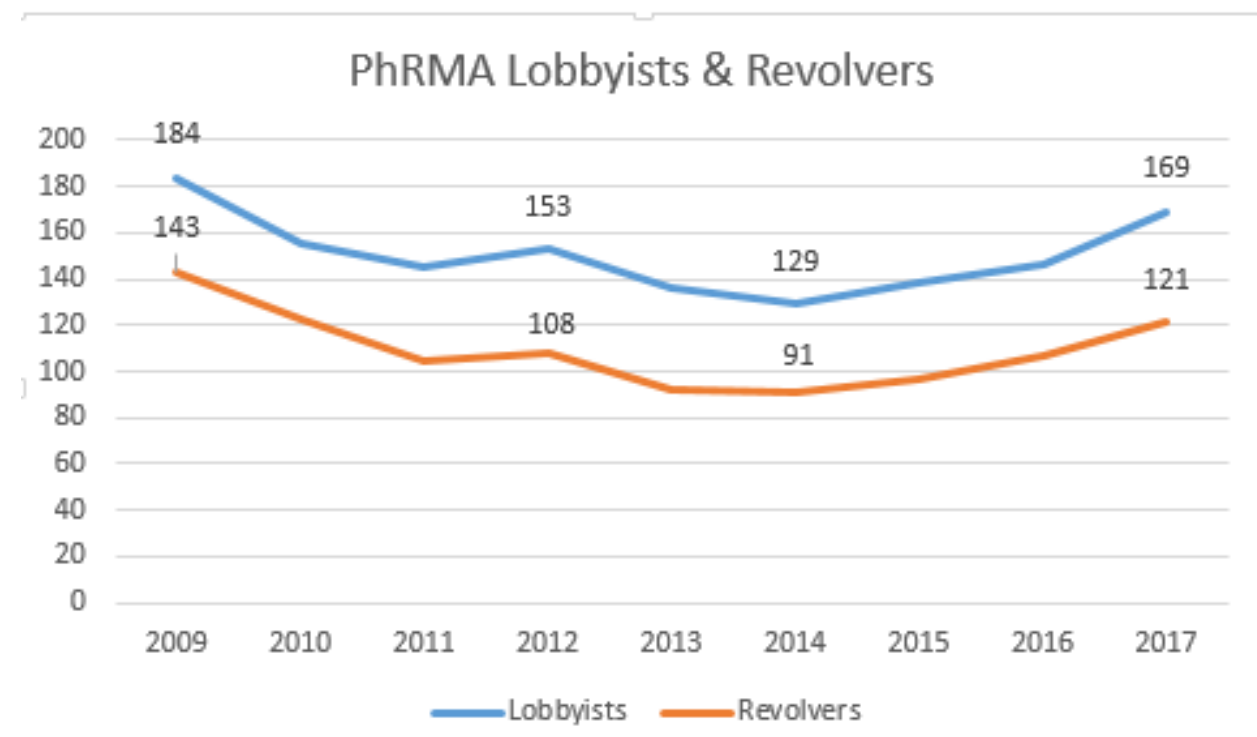

SOURCE: Data from Center for Responsive Politics, "Lobbyists Representing Pharmaceutical Research \& Manufacturers of America, 2017."

\section{Figure 13: PhRMA annual lobbying spending}

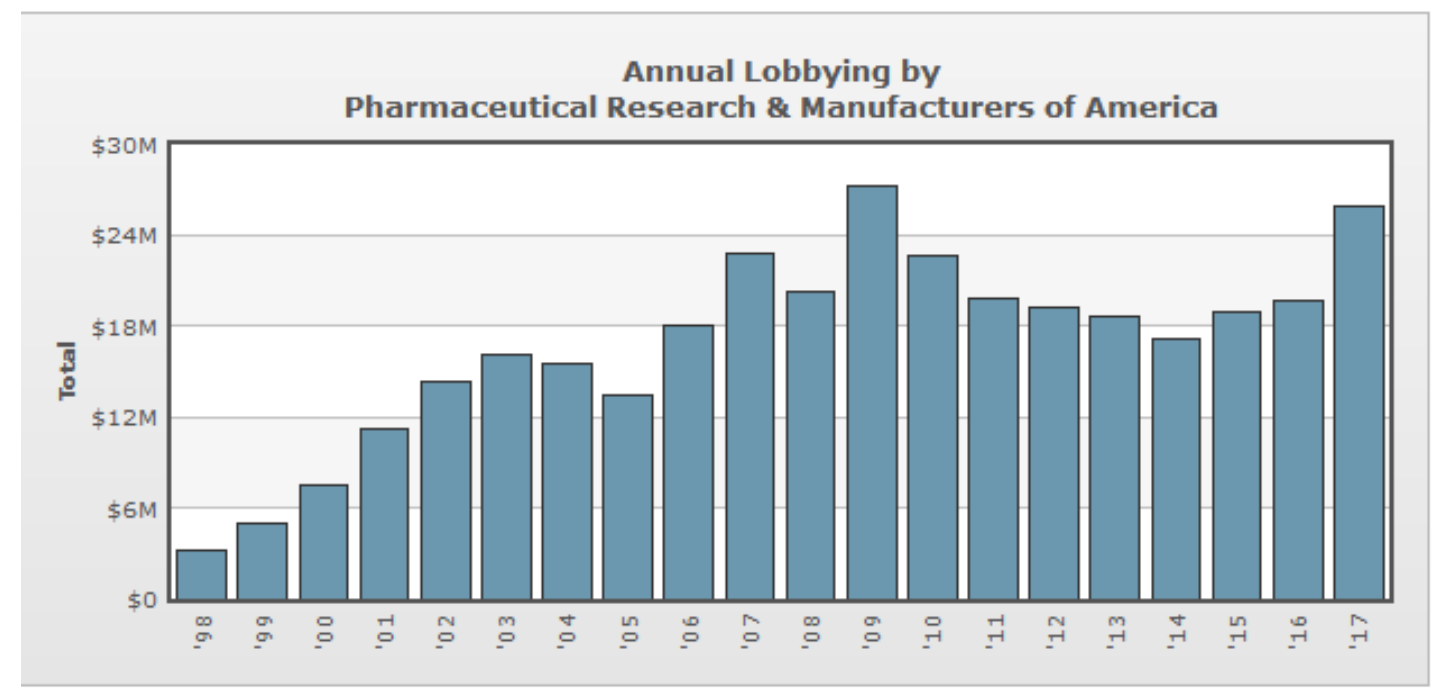

SOURCE: Data from Center for Responsive Politics, "Lobbyists Representing Pharmaceutical Research \& Manufacturers of America, 2017."

In 2017 , the industry spent $\$ 279$ million on lobbying, far more than the $\$ 200$ million average over the previous five years. ${ }^{114}$ PhRMA, the largest trade association, upped its spending by 31 percent to $\$ 25.8$ million. A second industry group, Biotechnology Innovation Organization (BIO), spent $\$ 9.4$ million. Among drug companies, Pfizer is consistently a top lobby spender, ranking second at $\$ 10.4$ million. Johnson \& Johnson (\$6.9 million) and Merck (\$6.2 million) ranked sixth and seventh, respectively, among pharmaceutical companies in 2017, while Abbott (\$4.2 million) ranked 13th. 
Figure 14: 2017 Tax lobbying by Pfizer, Johnson \& Johnson, Merck, and Abbott

\begin{tabular}{|l|l|l|l|l|l|l|l|}
\hline & $\begin{array}{l}\text { Total } \\
\text { lobbying } \\
\text { expenditure }\end{array}$ & $\begin{array}{l}\text { Total } \\
\text { lobbying } \\
\text { expenditure } \\
\text { on tax } \\
\text { issues }\end{array}$ & $\begin{array}{l}\text { Number } \\
\text { of tax } \\
\text { lobbyists }\end{array}$ & $\begin{array}{l}\text { Revolvers } \\
\text { as } \\
\text { percentage } \\
\text { of lobbyists }\end{array}$ & $\begin{array}{l}\text { Number } \\
\text { of } \\
\text { reports }\end{array}$ & $\begin{array}{l}\text { Number } \\
\text { of tax- } \\
\text { related } \\
\text { reports }\end{array}$ & $\begin{array}{l}\text { Tax reports } \\
\text { as } \\
\text { percentage } \\
\text { of all } \\
\text { reports }\end{array}$ \\
\hline Pfizer & $\$ 10,430,000$ & $\$ 2,503,200$ & 52 & $67 \%$ & 135 & 32 & $24 \%$ \\
\hline J\&J & $\$ 6,910,000$ & $\$ 1,105,600$ & 37 & $78 \%$ & 92 & 15 & $16 \%$ \\
\hline Merck & $\$ 6,230,000$ & $\$ 1,183,700$ & 52 & $85 \%$ & 139 & 26 & $19 \%$ \\
\hline Abbott & $\$ 4,150,000$ & $\$ 913,000$ & 43 & $74 \%$ & 102 & 22 & $22 \%$ \\
\hline
\end{tabular}

SOURCE: Data compiled by Oxfam from federal lobbying disclosure forms, OpenSecrets.org, and the Center for Responsive Politics. Estimates for how much a company spent on tax lobbying are calculated based on the following formula: (lobbying expense total reported by filer) $\times$ (total number of lobbying reports)/(number of reports made on tax).

The companies' increased lobby efforts should come as no surprise, given that both health care reform and tax reform were high on the agenda of Congress and the new administration. According to Oxfam's analysis of data from opensecrets.org, one-quarter of the lobby reports filed by Pfizer, Merck, and Abbott in the first half of 2017 were on taxation, as were one-third of Johnson \& Johnson's-as opposed to a 16 percent average between 2010 and $2016 .{ }^{115}$ Pharmaceutical companies are also major lobbyist on both US health issues like the opioid crisis and on issues related to enforcing strict intellectual property rules in other countries. ${ }^{116}$

Of the 184 lobbyists hired by the four companies in 2017, more than one-third had previously been employed by members of the two Congressional committees that write tax laws and oversee trade rules, including intellectual property provisions-the Senate Finance Committee and the House Ways and Means Committee-or by the committees themselves. ${ }^{117}$ Six of the lobbyists hired by Pfizer used to work for members of the Senate committee and one for the chair of the House committee. ${ }^{118}$ The chief of staff of a Finance Committee member was among three lobbyists hired by Johnson \& Johnson. ${ }^{119}$ Lobbying for Merck were a former ranking member of Ways and Means, Representative Jim McCrery, and six former staffers of committee members. ${ }^{120}$ Abbott also employed four lobbyists with direct connections to members of the two committees. ${ }^{121}$

Lobbying disclosures do not specify stances on issues, but the tax reforms called for by leaders of the four companies mirror several aspects raised in Congress, some of which were ultimately approved. ${ }^{122}$ As noted in Chapter 1 , the new law saved the four companies $\$ 50$ billion in US taxes, plus annual savings of \$4 billion from 2018 on.

\section{Campaign contributions}

Loyalty is often literally purchased in the Washington game. The trade association PhRMA and individual companies make frequent and substantial campaign contributions to members of Congress from both major parties. Between 2010 and 2016, PhRMA donated \$1.8 million to members, double what the US Chamber of Commerce kicked in. But the bulk of contributions come from companies and their political action committees (PACs). The four companies in this study donated a total of $\$ 43.9$ million during those years: $\$ 17.6$ million by Pfizer, $\$ 11.6$ million by Abbott, $\$ 9.5$ million by Merck, and $\$ 5.2$ million by Johnson \& Johnson. ${ }^{123}$ 
Members of President Trump's cabinet who have received multiple contributions from pharmaceutical companies when they were members of Congress include Attorney General Jeff Sessions, Director of National Intelligence Daniel Coats (who once worked as a lobbyist for PhRMA), Secretary of State (and former CIA Director) Mike Pompeo, Secretary of Energy James Richard Perry, and Vice President Mike Pence. ${ }^{124}$

Of the 20 members who received the greatest amount of cash from the pharmaceutical and health care industry in 2016, eight sit on the committees that write tax and trade rules: the House Ways and Means Committee and the Senate Finance Committee. In fact, only six of the 26 members of the Senate Finance Committee (plus two who joined it after the election), did not receive a campaign contribution from at least one the four companies or their PACs. Of these, five were Democrats and one a Republican. The remaining 22 senators received $\$ 118,000$ from Pfizer, $\$ 94,000$ from Merck, $\$ 68,500$ from Abbott, and $\$ 63,000$ from Johnson \& Johnson. Of those senators benefiting from the companies' largesse, on average, each Republican member received $\$ 24,000$ and each Democrat $\$ 15,500 .{ }^{125}$

The story is not dissimilar at the House Ways and Means Committee. Of the 39 members (plus eight who joined after the election), only 13 did not receive campaign contributions from any of the four companies or their PACs in 2016. Of these, eight were Democrats and six were Republicans. The remaining 34 congressmen received $\$ 137,000$ from Pfizer, $\$ 129,500$ from Abbott, $\$ 113,000$ from Merck, and $\$ 82,000$ from Johnson \& Johnson. Again, Democrats came cheap: on average, each Republican member received \$15,000 and each Democrat $\$ 11,500 .{ }^{126}$

US law allows companies and trade associations to fund political campaigns with so-called "dark money": unlimited donations to nonprofit organizations that are not required to disclose the identities of their donors. Such donations are tax deductible, and in fact only become public knowledge when the donors claim them on their taxes. The pharmaceutical industry directed substantial dark money to the American Action Network (AAN), which spent $\$ 10$ million in 2017 on an ad campaign to support repeal of the public health care program known as Obamacare. ${ }^{127}$ PhRMA gave nearly $\$ 6.1$ million to AAN in 2016. Since then AAN has given more than $\$ 19$ million to the Congressional Leadership Fund, which funds Republican campaigns for Congress. ${ }^{128}$

\section{Influence in developing countries}

Besides seeking to structure the US intellectual property and tax systems in the industry's favor, pharmaceutical corporations have strategically deployed these influencing means to get the US government to pressure developing countries for similar favorable treatment, using trade relations as leverage.

Here is how it works: a pharmaceutical corporation lobbies members of Congress about a country's "unfair" practices-often related to taxation or the issuance of compulsory licenses (which authorize generic production and marketing of a patented drug). ${ }^{129}$ The corporation typically alleges that the country's laws and regulations cut into its profits, which the company claims hinders innovation and employment of Americans.

After hearing this pitch, members of Congress will often bring the corporation's concerns to the US Trade Representative or even to the president. ${ }^{130}$ Such actions reinforce the company's efforts to lobby the US Trade Representative directly. The US Trade

Representative then publicly condemns the specific practices of the country in question and may threaten trade sanctions. Colombia's efforts to reduce the price of medicines, for example, evoked threats in 2016 to withhold aid for its peace process and later to block its accession to the OECD. ${ }^{131}$ 
Such pressure presents developing country governments with an untenable choice: either ensure access to medicines for their citizens or increase trade to promote economic growth. To reduce poverty and inequality, governments actually need to do both.

Trade negotiations for bilateral or regional free trade agreements are one important venue for pushing developing countries to accept the pharmaceutical companies' demands. ${ }^{132}$ When put into force, these trade agreements lock in strict intellectual property protections virtually forever in all countries party to the agreement, restricting their ability to use flexibilities in the WTO's Agreement on Trade-Related Intellectual Property (known as the TRIPS agreement), such as compulsory licensing. But they can take a very long time to negotiate and approve. A quicker and often more effective vehicle for ongoing pressure is the US Trade Representative's annual Special 301 Report, which establishes a "Priority Watch List" and a secondary "Watch List" of countries not complying with US wishes.

Federal law allows the US government administration to impose trade sanctions against "priority foreign countries"-those it determines do not meet its interpretation of acceptable IP standards. Although this designation has not been used in recent years, likely due to concerns about the legality of unilateral sanctions within the WTO, the annual Special 301 Report has focused attention on the watch lists, which in effect serve as a means of coercion to promote compliance with US aims. ${ }^{133}$

Nearly all of the countries that PhRMA, BIO, and the corporations complain about find themselves on these lists, and the US government critiques of country policies in the annual Special 301 report tend to mirror reflect concerns raised in pharmaceutical company submissions, rather than taking into account very different critiques raised by non-profit organizations representing civil society concerns. ${ }^{134}$ The 2018 Priority Watch List features 12 countries, including India, Chile, Algeria, Indonesia, and Argentina, all retained from 2017, plus a new addition, Colombia. ${ }^{135}$ Guatemala, Lebanon, Thailand, and Peru are among the 24 countries on the Watch List. ${ }^{136}$ Developing country taxes and tariffs on imported US medicines are a concern cited frequently in the Special 301 reports, although not in 2018.

India is cited for possible use of compulsory licensing and patent revocation for its drug price control policies and for high customs duties; Chile for failing to "deliver any tangible progress on outstanding IP commitments in recent years"; Algeria for its "ban on a vast number of imported pharmaceutical products and medical devices in favor of local products"; Indonesia and Argentina for supposed deficiencies in their protection and enforcement of intellectual property, as well as market access barriers for pharmaceutical products. ${ }^{137}$

Naturally, the corporations also lobby developing country governments directly-in addition to via free trade agreements and the Special 301 report. Besides demanding lower taxes, they work in concert with US officials to push countries to adopt and enforce stricter intellectual property protections, for example, by extending the effective life of patents or loosening the criteria for patent approval. ${ }^{138}$ They press public health authorities to include their products in the country's Essential Medicines List, and thus make them eligible for procurement and/or insurance reimbursement-both of which have been cited as magnets for corruption. ${ }^{139}$ And the corporations may not be above bribery. (See "Bribery, Kickbacks, and Other Crimes" in Chapter 3.)

\section{Target India}

The industry's clout in Washington was evident in a campaign the companies waged in 2013. Pfizer spokesman Roy Waldron launched it at a Senate Finance Committee hearing in March of that year, where he railed at India for issuing its first compulsory license even though it fully complied with the WTO TRIPS agreement. ${ }^{140}$ India is the world's largest and cheapest manufacturer of generic medicines, often referred to as "the pharmacy of the developing world." 
By June a number of large US industry associations, including PhRMA, BIO, the US Chamber of Commerce, and the National Association of Manufacturers, had banded together to form the Alliance for Fair Trade in India to oppose what they called "a proliferation of trade barriers." What looked like a broad business alliance, however, was led by the pharmaceutical companies, and its target was India's "use and threatened use of compulsory licensing" as well as "measures in Indian law that add an onerous and unnecessary additional criterion for the patentability of medicines."142

On the same day the alliance was announced, 170 members of Congress wrote President Obama condemning India. Two days later, 40 US senators followed suit in a letter to the secretary of state, and members of the House Ways and Means Committee wrote their own letters to the president. A House subcommittee held a hearing a week later, much of which was devoted to Pfizer's complaints about generic competition. ${ }^{143}$ Two senators and two representatives soon followed up with a letter to the US Trade Representative requesting an investigation into "India's unfair trade practices." 144 In September, 14 state governors added their own letter to President Obama, questioning whether India strikes the right balance between public health and protecting intellectual property. ${ }^{145}$

India remained on the US Trade Representative's Priority Watch List for a number of reasons beyond compulsory licensing, including India's pro-public health intellectual property law that tightens the criteria for patent approval while staying in accord with the WTO's TRIPS agreement. Pharmaceutical companies continue to lobby against the Indian IP law even though India upholds its law and assesses patent requests from US pharmaceutical companies in accordance with its regulatory regime. ${ }^{146}$ The corporations' calls for sanctions seemed to ease in 2016 after India offered private reassurances that it would not use compulsory licenses for the purpose of promoting its generics industry. ${ }^{147}$ Even so, India remains on the Priority Watch List today.

In a similar case, Congressional staffers informed Colombian Embassy personnel in Washington that Congress could hold back promised aid for Colombia's peace process if Colombia continued seeking to lower prices on medicines by moving toward issuing a compulsory license in 2016 on a medicine to treat cancer. Colombian Embassy personnel noted "the direct relationship that exists between a significant group of Members of Congress with the US pharmaceutical industry" when indicating to their government that the issue could affect US aid to their country. ${ }^{148}$ Two years later, coinciding with concerns raised by PhRMA, Republican members of Congress pressed the US government to block Colombia's petition to join the OECD, and the US Trade Representative also elevated the country to the Priority Watch List in 2018-as PhRMA had called for since 2016-for, among other things, not applying stronger IP protections for medicines. ${ }^{149}$

Another example of pharmaceutical company lobbying activities is an attempt to derail reforms to intellectual property laws in South Africa. A leaked email from Merck in South Africa revealed that a number of major pharmaceutical companies including Johnson \& Johnson and Pfizer hired a major US PR company to work to stop proposed changes to South Africa's intellectual property legislation. The companies tried to disclaim their campaign after the issue became public. ${ }^{150}$ And more recently, in Chile, companies have been lobbying intensively to stop the Chilean government from issuing a compulsory license for a medicine to cure Hepatitis C. ${ }^{151}$ 


\section{Developing countries challenge the corporate giants}

Pharmaceutical companies become most incensed when developing countries allow competition from generics in order to bring prices down. The WTO Agreement on TradeRelated Intellectual Property (TRIPS agreement) permits countries to issue "compulsory licenses" to allow generic production, with fair compensation to the patentholder, even if the patentholder disagrees. The companies hate compulsory licenses because they strike at the core of their ability to reap superprofits via monopoly pricing.

An illustrative case is Thailand's experience with ritonavir (brand name Kaletra), Abbott's antiretroviral medicine for treating people living with HIV. ${ }^{152}$ In January 2007, when the country had the highest incidence of the disease in Asia, the Thai government could not afford the cost (\$2,200 per patient per year) and issued a compulsory license. ${ }^{153}$ Abbott accused Thailand of "stealing" intellectual property, and proceeded to withdraw all its applications for new products in the country, including a heat-stable version of Kaletra. ${ }^{154}$

The industry trade association PhRMA argued that Thailand was unfairly placing the burden of financing research on US consumers. Billy Tauzin, PhRMA's president and CEO at the time (and a former congressman from Louisiana), said that Thailand's action could cause the entire system of protecting intellectual property "to crumble." ${ }^{155}$ Abbott proceeded to lower the price of Kaletra in more than 40 countries to forestall similar licenses. Yet it insisted Thailand revoke the compulsory license if it wanted the discount. Thailand refused. ${ }^{156}$

Even though Thailand was well within its WTO rights, 12 members of Congress wrote a joint letter to the US Trade Representative expressing their concern. ${ }^{157}$ Soon thereafter, Thailand was moved from the Watch List to the Priority Watch List. Interestingly, in the following election, Abbott contributed to the campaigns of all but one of the congressmen who signed the letter, as did Merck. ${ }^{158}$

Thailand stood firm and Mexico and Colombia-where Abbott was charging $\$ 3,000$ to $\$ 6,000$ per patient per year for Kaletra, even though the same product was priced $\$ 1,000$ in other middle-income countries-soon made noises about following suit. ${ }^{159}$ Thailand ultimately joined the Clinton Foundation's medicine pool procurement and managed to get a generic equivalent to Kaletra for $\$ 695$. $^{160}$

Official cables revealed through Wikileaks offer a peek into the normally hidden role of US embassies in such dramas. When the Ecuadorean government declared its intention to issue compulsory licenses in 2009 (on HIV medicines, including ritonavir), US Ambassador Heather M. Hodges notified Abbott of the decision, but also asked the company not to mention the US governments' involvement. ${ }^{161}$ Other leaked documents reveal a similar role for the US Embassy in Brazil as a channel to Merck, Abbott, and others in 2010. ${ }^{162}$

The companies may loathe them, but compulsory licenses are an effective tool for making medicines affordable. In its September 2016 report, the UN Secretary-General's High-Level Panel on Access to Medicines decried the "cloud of controversy, intimidation and legal uncertainty associated with compulsory licenses," which "has impeded the possibility of creative arrangements between governments and corporations with respect to strategies for the production and distribution of health technologies." 163 The panel noted that restricted access to medicines as a result of intellectual property rules is a problem for rich and poor countries alike.

\section{Patient advocacy}

Beyond political pressure and threats, the companies engage in clever grassroots campaigns. When a medicine is excluded from eligibility for government purchase owing to its exorbitant price, those complaining loudly in the press are often not the companies, but 
rather nonprofit "patients rights" organizations—which turn out to be funded by the companies.

The Peruvian investigative news agency OjoPúblico found that 12 major pharmaceutical companies, including Merck, Pfizer, Johnson \& Johnson, and Abbott, fund more than 65 such patient advocacy groups in Latin America, as well as their umbrella organization, the International Alliance of Patients' Organizations (IAPO). ${ }^{164}$ IAPO's 2014 budget of $\$ 3.38$ million included $\$ 100,000$ from Johnson \& Johnson, $\$ 60,000$ from Pfizer, and $\$ 43,000$ from Merck. ${ }^{165}$

\section{Restrict influence peddling}

Pharmaceutical companies are big players in Washington. They buy the loyalty of lawmakers through campaign contributions, they hire former government officials and lawmakers to lobby for them, and they place their executives and lobbyists in powerful government positions. They have to be there. The US government is a large purchaser of their products. More importantly, government regulations structure and enforce the intellectual property and tax systems that allow them to set prices at will and hide their profits in overseas tax havens. And without the clout of the US government, these companies would have a harder time imposing their desires on governments around the world.

Though the companies depend on well-functioning societies for their continued success, they would prefer that others pay to keep governments running. Now we turn to a closer examination of the business model that makes pharmaceutical companies so profitable and their executives so wealthy-a model that constitutes an important driver of extreme inequality across the world. 


\section{Chapter 3: Drug companies and inequality: "Heads I win, tails you lose"}

Pharmaceutical companies present a notorious example of an approach to business that is sadly common in today's world-one in which boards and executives view their mandate solely as maximizing returns to wealthy shareholders. ${ }^{166}$

The reigning pharmaceutical company ethos appears to hold that overcharging for medicine, dodging taxes, and buying political influence are proper and necessary ways to conduct business affairs. Ideological blinders seem to have led some pharmaceutical leaders so far as to consider appropriate the promotional policies that caused widespread opiate addiction in communities across the United States, not to mention continued suffering and death for lack of medicines in poorer countries around the world. ${ }^{167}$ The profits of these companies have generated huge wealth for a few, at huge human cost to the many.

This chapter will examine the structures that allow pharmaceutical corporations to set and raise prices at will, yet fail to encourage them to invest more in research and development for innovation; the ever-increasing proportion of corporate revenue spent on dividends, stock buybacks, and executive pay; and how these companies' pursuit of maximizing returns to wealthy shareholders drives inequalities between rich and poor, between men and women, and between advanced economies and developing ones.

\section{Patents and prices}

President Trump famously boasted before taking office that he would bring down prescription drug prices. Yet in his first 14 months in office, pharmaceutical companies continued to hike the prices of hundreds of drugs. According to an analysis by Pharmacy Benefits Consultants, 20 prescription drugs saw their prices rise by more than 200 percent. ${ }^{168}$ Sixteen of Pfizer's drugs rose over 34 percent in price; nine of Merck's rose over 21 percent. In response to pressure by Trump, pharma companies recently announced a temporary halt to price increases_but this halt extends only until early 2019 , after the US midterm elections in November 2018. ${ }^{169}$

Unlike most products, the price of brand-name medicines has practically no relationship to the cost of manufacturing. In order to foster innovation, governments grant patentholders monopolies-no other company is allowed to produce or sell those drugs-for 20 years. ${ }^{170}$ Absent any competition, the companies may charge whatever they believe the market will bear. Because many of their products are necessities, not luxuries that the consumer can forego, people will sacrifice nearly anything to pay what the companies ask.

A recent study by researchers from Harvard University and the University of Liverpool examined the cost of the standard medicines used for treating cancer. ${ }^{171}$ The high price of cancer treatments constitutes a serious problem in the US, let alone in low- and middleincome countries, where the monthly cost often exceeds the patient's annual income. To arrive at what standard economics would consider a reasonable price, the researchers added up the cost of making the active ingredient and the pill, capsule, or dilution, plus a 10 percent profit and a 26.6 percent average tax on profits.

A "reasonable price" turned out to be 86 percent less than what the companies charge in United States and 85 percent below their price in the United Kingdom. In other words, rather than accept a reasonable 10 percent profit margin, it seems the companies earn on average nearly 100 percent. A standard 12-week course of Pfizer's breast cancer drug paclitaxel, for example, can be produced for $\$ 1.16$, yet sells for $\$ 276$ in the US and $\$ 912$ in the UK. ${ }^{172}$ This study did not take into account the cost of research and development for these medicines, which companies normally keep as a commercial secret. 
Besides the legal monopoly and the fact that medicines are necessities, a third factor makes medicine prices behave unlike other products. Many of them are bought not by consumers, but by public institutions, such as health ministries in developing countries and Medicare or the Veterans Administration in the United States, which then provide them at subsidized prices to patients. Prices paid by public institutions are negotiated in a nontransparent process that is often more political than economic. Governments enter negotiations without knowing what other countries pay, due to the lack of transparency and confidentiality clauses, which mean that the prices paid by governments vary hugely, even if they have similar income levels. As noted in Chapter 2, companies lavish attention on decision makers, who are often bound by rules set up by politicians linked to the companies. ${ }^{173}$ For example, since its inception, Medicare is barred by US law from negotiating the price on bulk purchases of medicines.

\section{Rewarding innovation?}

The intellectual property system was designed as a social contract between the government and citizens to foster innovation, considered a public good in that its benefits can be enjoyed by all of society without exclusion. Governments would grant intellectual property protection not as a right, but as a public policy instrument aimed at stimulating innovation by providing an incentive to reward the inventor. But getting the right balance between incentivizing innovation and enabling society to enjoy its benefits is key.

In practice, the IP system has not delivered on its promise to incentivize R\&D needed for medicines. In recent years relatively few medical breakthroughs have been achieved by the big companies' R\&D. Instead, the IP system has delivered superprofits to pharmaceutical companies. The taxpayer-funded US National Institutes of Health in the United States is by far the largest investor in health research, providing grants to universities and others. A recent study found that all 210 drugs approved in the United States between 2010 and 2016 benefited from public-funded research, either directly or indirectly. ${ }^{174}$ European governments also provide significant funding for research and innovation. ${ }^{175}$ The source for these direct public investments, of course, is taxes.

The pharmaceutical companies, for their part, do invest in R\&D. The US Government Accountability Office (GAO) found that from 2008 through 2014, worldwide companyreported R\&D spending increased from $\$ 82$ billion to $\$ 89$ billion annually. ${ }^{176}$ During the same period, federal spending on basic research remained stable at around $\$ 28$ billion. ${ }^{177}$

Yet the GAO study also found that small biotechnology companies were responsible for an increasing share of R\&D, and that large companies have turned to acquiring small ones in order to obtain their patents. While the large companies present themselves to the public as white-coated scientists making discoveries in the lab, in actuality they behave more like hedge funds, buying assets developed by others.

What's more, the companies can deduct their R\&D expenses from their taxes. As a result, patients often pay twice for medicines: through their tax dollars for public investment in research and at the pharmacy where companies set high prices because they can; or three times if we count the extra tax dollars we pay because the companies don't.

The companies' R\&D spending is also smaller than the billions they spend on marketing. In 2013 Johnson \& Johnson spent more than twice as much on sales and marketing than on R\&D ( $\$ 17.5$ billion vs. $\$ 8.2$ billion), as did Pfizer ( $\$ 11.4$ billion vs. $\$ 6.6$ billion), while Merck spent 20 percent more ( $\$ 9.5$ billion vs. $\$ 7.5$ billion). ${ }^{178}$ Interestingly, although drug ads on television are ubiquitous in the United States, nearly all of the companies' marketing efforts target not the public, but doctors and nurses. The top 10 companies spent $\$ 3$ billion marketing to consumers and $\$ 24$ billion marketing to health care professionals in $2013 .{ }^{179}$ All of these costs were tax deductible. 
Figure 15: Drug company spending on sales and marketing versus research and development

\begin{tabular}{|l|c|c|}
\hline \multicolumn{3}{|l|}{$\begin{array}{l}\text { Spending on sales and marketing vs. research and } \\
\text { development, 2013 }\end{array}$} \\
\hline & $\begin{array}{c}\text { Sales and } \\
\text { marketing (billions) }\end{array}$ & $\begin{array}{c}\text { Research and } \\
\text { development (billions) }\end{array}$ \\
\hline Abbott & Not available & Not available \\
\hline $\begin{array}{l}\text { Johnson \& } \\
\text { Johnson }\end{array}$ & $\$ 17.5$ & $\$ 8.2$ \\
\hline Merck & $\$ 9.5$ & $\$ 7.5$ \\
\hline Pfizer & $\$ 11.4$ & $\$ 6.6$ \\
\hline Totals & $\$ 38.4$ & $\$ 22.3$ \\
\hline
\end{tabular}

SOURCE: Data adapted from Ana Swanson, "Big Pharmaceutical Companies Are Spending Far More on Marketing Than Research," Washington Post, February 11, 2015, https://www.washingtonpost.com/news/wonk/wp/2015/02/11/bigpharmaceutical-companies-are-spending-far-more-on-marketing-than-research/?utm_term=.afdeddef6e77.

\section{High drug prices drive gender inequality}

High medicine prices disproportionately harm women, because women have greater health needs than men:

- Women live longer and thus need care for more years ${ }^{180}$

- The costs of childbirth and contraceptives tend to fall on women ${ }^{181}$

- Sexual violence-experienced by one in three women during their lives ${ }^{182}$-often entails a need for health care ${ }^{183}$

- Even nutrition-related health issues, such as anemia, are more prevalent in women. ${ }^{184}$ In developing countries, women's responsibility for household chores can also increase their need for health care:

- Cooking with charcoal exposes women to harmful carbon monoxide, and contributes to millions of deaths annually ${ }^{185}$

- Collecting water or washing clothes in rivers or ponds can lead trachoma and schistosomiasis ${ }^{186}$

- Women are usually responsible for caring for family members when they fall ill. This care work means they are more likely to come into close and prolonged contact with infectious diseases and may fall ill themselves. ${ }^{187}$

These greater health needs add up to higher health care costs, which is why, prior to the Affordable Care Act, US insurance companies charged up to 81 percent more for women than men. ${ }^{188}$

The research agenda of pharmaceutical companies also disadvantages women:

- Diseases that primarily affect poor women, men, and children are largely ignored, including sleeping sickness ${ }^{189}$

- Data is rarely analyzed or reported separately by sex

- Women have traditionally been excluded from biomedical and toxicology research, thus the resulting medicine may have different effects on women. ${ }^{190}$ 


\section{Where do the profits go?}

The companies insist that they need high revenues in order to invest in R\&D to achieve new breakthroughs in medicine. Several inconvenient facts belie this argument: First, much of the funding for research and development comes from taxpayers. Second, the major companies have not by and large achieved any breakthroughs in recent years (rather, they have purchased innovations from smaller companies), and they have hardly invested in R\&D on neglected diseases, which primarily affect people in poverty. The third inconvenient fact is what major US pharmaceutical companies do with their astoundingly high profits.

Economist William Lazonick of the University of Massachusetts and his colleagues crunched the numbers. They found that between 2006 and 2015, 18 major drug companies distributed nearly half of their $\$ 522$ billion in profits as dividends to shareholders and spent the other half on buybacks to boost their stock prices. During that decade, spending on research and development (which comes from revenue before profits) amounted to $\$ 465$ billion.

As Lazonick points out: the total of $\$ 261$ billion spent on buybacks alone was equivalent to 56 percent of these companies' combined R\&D expenditures. That $\$ 261$ billion could have been returned to households in the form of lower drug prices without infringing on R\&D spending, while shareholders would still have received ample dividends. Or these funds could have been allocated to the development of drugs for high-priority access areas that are otherwise underfunded and underserved. ${ }^{191}$

The numbers for Abbott, Johnson \& Johnson, Merck, and Pfizer are even more pronounced. These companies spent $\$ 341.4$ billion of their $\$ 1.8$ trillion in revenue during that decade on buybacks and dividends-equivalent to 19 percent of their earnings. And on research and development they spent $\$ 259.4$ billion, or only 14 percent-and most of that went not to research, but to development of products discovered by others. ${ }^{192}$ The following table provides the precise data.

Figure 16: Pharmaceutical company spending on stock buybacks, cash dividends, and research and development 2006-2015

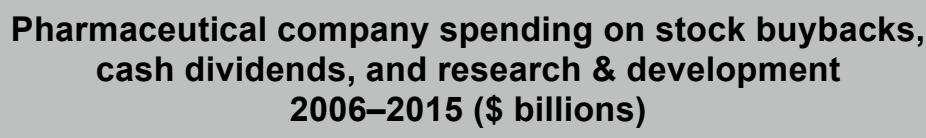

\begin{tabular}{|l|r|r|r|r|r|r|r|}
\hline Company & Revenue & $\begin{array}{l}\text { Stock } \\
\text { buybacks } \\
\text { (BB) }\end{array}$ & $\begin{array}{l}\text { Cash } \\
\text { dividends } \\
\text { (DV) }\end{array}$ & $\begin{array}{l}\text { BB + } \\
\text { DV }\end{array}$ & $\begin{array}{l}\text { Research } \\
\text { and } \\
\text { developmen } \\
\text { t (R\&D) }\end{array}$ & $\begin{array}{l}\text { BB+DV } \\
\text { as } \\
\text { percent } \\
\text { age of } \\
\text { revenue }\end{array}$ & $\begin{array}{l}\text { R\&D as } \\
\text { percentag } \\
\text { of revenue } \\
\text { Abbott }\end{array}$ \\
\hline of & 285.1 & 13.1 & 20.8 & 33.9 & 26.6 & $12 \%$ & $9 \%$ \\
\hline J\&J & 649.4 & 42.4 & 61.1 & 103.5 & 80.9 & $16 \%$ & $12 \%$ \\
\hline Merck & 365.2 & 29.7 & 43.1 & 72.8 & 69.3 & $20 \%$ & $19 \%$ \\
\cline { 2 - 9 } \\
Pfizer & 538.8 & 63.2 & 68.0 & 131 & 82.6 & $24 \%$ & $15 \%$ \\
\hline Totals & $1,838.5$ & 148.4 & 193 & 341.4 & 259.4 & $19 \%$ & $14 \%$ \\
\hline
\end{tabular}

SOURCE: Adapted from William Lazonick, Matt Hopkins, Ken Jacobson, Mustafa Erdem Sakinç, and Öner Tulum, "US Pharma's Financialized Business Model," Institute for New Economic Thinking Working Paper 60 (July 13, 2017), https://www.ineteconomics.org/uploads/papers/WP_60-Lazonick-et-al-US-Pharma-Business-Model.pdf. 
All of the companies spent more on their shareholders than on research and development. Pfizer spent nearly one-quarter of its revenue (24 percent) on dividends and stock buybacks, and invested only 15 percent in research and development. Merck spent nearly as much on R\&D (19 percent) as on dividends and buybacks (20 percent). The other two companies fall in between: Johnson \& Johnson spent 16 percent on dividends and buybacks, and 12 percent on R\&D; Abbott 12 percent of revenue on dividends and buybacks, and 9 percent on R\&D.

This phenomenon seems to have grown over time. Lazonick and colleagues point out that in recent years many companies, including Pfizer and Merck, routinely distribute more than 100 percent of profits to shareholders, generating the extra cash by reducing reserves, selling off assets, taking on debt, or laying off employees. ${ }^{193}$

The study's authors come to a striking conclusion: "The key cause of high drug prices, restricted access to medicines and stifled innovation, we submit, is a social disease called 'maximizing shareholder value."' 194 As if to confirm this assertion, in the weeks following the approval of the new US tax law in 2017, Pfizer and Merck announced new stock buybacks for $\$ 10$ billion apiece. ${ }^{195}$

An analysis by the office of US Senator Cory Booker found that not a single pharmaceutical company forecast lowering prescription drug prices as a direct result of the generous tax cut they received in 2017 . Instead they announced $\$ 45$ billion in new stock buyback programs. Out of the more than $\$ 200$ billion in recent buyback announcements across all industries, five pharmaceutical companies alone accounted for approximately one-fifth of the total. ${ }^{196}$

Despite the companies' claims to the contrary, their high profits have not increased their investment in R\&D, and they have spent the past two decades living off a handful of blockbuster drugs, and investing in efforts to extend those monopolies as much as possible, with very little in the pipeline to replace them when they go off patent. ${ }^{197}$ According to research by Lazonick and his team, since 2001 Pfizer, for example, has launched only four internally developed products, the last one in $2005 .{ }^{198}$

\section{Executive pay}

One reason why stock buybacks are so popular with corporations is the loophole written into the 1996 US law on executive compensation. While the intent of the law was to rein in runaway CEO pay, the loophole allowed for unrestricted "performance pay," with performance measured by increases in the price of company stock. Buybacks give a boost to stock prices by reducing the total number of shares. Most outrageously, performance pay for executives was deductible from the companies' taxes-an element that was thankfully eliminated in the 2017 tax reform.

Needless to say, drug company executives are some of the highest-paid executives around, making multiple millions annually, much of it through stock-based compensation.

Pharmaceutical CEOs' average compensation in 2015 was $\$ 18.5$ million, 71 percent greater than the median earned by executives in all industries. ${ }^{199}$

Even while Pfizer hiked the price of dozens of drugs in 2017, the compensation of its CEO leaped up by 61 percent, putting his total compensation at more than $\$ 26$ million. ${ }^{200}$ His deal is indicative of how CEO pay is structured to make stock price the measure of success. His massive compensation for 2017 included $\$ 13.1$ million in stock linked to financial goals and stock price, in addition to an $\$ 8$ million "special equity award" linked to a rise in the company's stock. ${ }^{201}$ In 2018 his pay rose again by 54 percent. ${ }^{202}$

The following table shows how much the CEOs of the four companies under consideration earned in recent years. Fluctuations in their compensation over time are due primarily to 
changes in the value of company stock, since stock and stock options made up 55 percent to 77 percent of their compensation over that period.

Figure 17: Drug company CEO pay ${ }^{203}$

\begin{tabular}{|c|c|c|c|c|c|c|}
\hline \multicolumn{7}{|c|}{ CEO compensation } \\
\hline Company & 2013 & 2014 & 2015 & 2016 & 2017 & $\begin{array}{c}\text { Total } \\
2013- \\
2016\end{array}$ \\
\hline Pfizer & $\begin{array}{l}\$ 17.7 \\
\text { million }\end{array}$ & $\begin{array}{l}\$ 18.0 \\
\text { million }\end{array}$ & $\begin{array}{l}\$ 14.4 \\
\text { million }\end{array}$ & $\begin{array}{l}\$ 17.0 \\
\text { million }\end{array}$ & $\begin{array}{l}\$ 26.2 \\
\text { million }\end{array}$ & $\begin{array}{l}\$ 67.1 \\
\text { million }\end{array}$ \\
\hline Merck & $\begin{array}{l}\$ 12.5 \\
\text { million }\end{array}$ & $\begin{array}{l}\$ 21.4 \\
\text { million }\end{array}$ & $\begin{array}{l}\$ 19.9 \\
\text { million }\end{array}$ & $\begin{array}{l}\$ 17.0 \\
\text { million }\end{array}$ & $\begin{array}{l}\$ 17.1 \\
\text { million }\end{array}$ & $\begin{array}{l}\$ 70.7 \\
\text { million }\end{array}$ \\
\hline Abbott & $\begin{array}{l}\$ 20.5 \\
\text { million }\end{array}$ & $\begin{array}{l}\$ 16.2 \\
\text { million }\end{array}$ & $\begin{array}{l}\$ 18.8 \\
\text { million }\end{array}$ & $\begin{array}{l}\$ 16.4 \\
\text { million }\end{array}$ & $\begin{array}{l}\$ 15.6 \\
\text { million }\end{array}$ & $\begin{array}{l}\$ 71.9 \\
\text { million }\end{array}$ \\
\hline $\begin{array}{l}\text { Johnson \& } \\
\text { Johnson }\end{array}$ & $\begin{array}{l}\$ 15.2 \\
\text { million }\end{array}$ & $\begin{array}{l}\$ 20.4 \\
\text { million }\end{array}$ & $\begin{array}{l}\$ 21.1 \\
\text { million }\end{array}$ & $\begin{array}{l}\$ 21.2 \\
\text { million }\end{array}$ & $\begin{array}{l}\$ 22.8 \\
\text { million }\end{array}$ & $\begin{array}{l}\$ 77.9 \\
\text { million }\end{array}$ \\
\hline
\end{tabular}

SOURCE: Annual Equilar 200 studies, as reported in Equilar and New York Times, "The 10 Highest-Paid CEOs in 2017."

Using so much of profits for buybacks and compensation may end up undermining these companies' long-term stability. At the same time, the lax tax rules the companies have successfully lobbied for have helped drain the public sector of its capacity to invest in R\&D.

\section{Bribery, kickbacks, and other crimes}

Major pharmaceutical companies are charged with violating US state or federal law with alarming regularity. Since 2008, they have reached settlements with authorities in 331 cases, paying out more than $\$ 28$ billion in penalties. Settling such cases out of court keeps the details of corporate misdeeds from being aired in public, and, perhaps more importantly, no clear body of case law is built for the future.

The most common charge is defrauding government health programs, followed by deceptive marketing. ${ }^{204}$ Paying kickbacks to doctors, hospitals, or others, including bribing foreign officials, comes third. Defrauding tax authorities is the eighth-most-common charge. In the past two years, six of the 12 settlements on kickbacks involved bribery of foreign governments, including Russia, Ukraine, and Mexico, though none by the four companies that are the focus of this report. However, the largest fine ever for such behavior $(\$ 70$ million) was paid by Johnson \& Johnson in 2011 for bribing doctors and health officials in Greece. That same year, the company settled with the UK government for bribing Saddam Hussein. ${ }^{205}$ And in 2012, Pfizer paid a $\$ 45$ million penalty for bribing officials in Bulgaria, China, Croatia, Czech Republic, Italy, Kazakhstan, Russia, and Serbia. ${ }^{206}$

Most recently, in May 2018, Pfizer agreed to pay almost \$24 million to settle charges it used a supposedly independent charity, Patients Access Network Foundation, to pay kickbacks to cover the co-payments of US Medicare patients taking three of its drugs. ${ }^{207}$ Pfizer has made the most settlements of any company (34 since 1991) and has paid the second-largest and third-largest penalties ( $\$ 4.7$ billion and $\$ 2.3$ billion)—also for kickbacks. ${ }^{208}$ Charges of kickbacks led Johnson \& Johnson to pay the fourth-largest settlement ( $\$ 2$ billion in 2013), Abbott to pay the fifth-largest ( $\$ 1.5$ billion in 2012), and Merck to pay the eighth-largest (\$950 million in 2011). ${ }^{209}$ 


\section{The global divide}

All governments must do more to crack down on corporate tax dodging. But rich countries, especially the US, bear the main responsibility for the additional damage caused by a business model that prioritizes returns to shareholders over public health and access to medicine. Price gouging and aggressive tax avoidance undermine efforts to fight poverty, while the rigged rules that give pharmaceutical companies monopolies inflate the price of medicine and deprive patients of the medicines that can save their lives.

The United States boasts the highest drug prices in the world, and, not surprisingly, it constitutes by far the largest pharmaceutical market in both total and per capita terms. ${ }^{210}$ But spending on medicine in developing countries is not inconsequential. It grew by nearly 12 percent a year in 2012-2016, and is expected to grow by 6 to 9 percent over the coming five years. ${ }^{211}$ Already, the biggest drug companies earn between 20 and 42 percent of their revenue in developing countries, the bulk of it in China and other middle-income countries, including India, Turkey, Mexico, and Colombia, where noncommunicable diseases like diabetes, heart disease, and cancer are becoming much more prevalent. ${ }^{212}$ The chronic nature of these diseases implies a continuous need for medicines, thus steady profits. ${ }^{213}$ Perhaps it is not surprising that all of these countries are on one or the other of the US Trade Representative's Watch Lists.

Peru offers an interesting example of the bind developing countries find themselves in. Under pressure from the pharmaceutical companies, in 2001 and 2005 the Peruvian Congress eliminated tariffs and sales taxes on imported anti-cancer and diabetes medicines and their raw ingredients in hopes of alleviating the astronomical price of medicine. Medications by Pfizer, Johnson \& Johnson, Merck, and Abbott were among those that received tariff exemptions.

The tariff elimination failed to deliver on its intended goal of reducing drug prices. Only three of the 10 cancer medicines and four of the 18 diabetes drugs saw price declines. Most prices, including those of Pfizer's anti-cancer drug Sutent and Abbott's diabetes drug Actos, actually rose more than 20 percent after duties were eliminated. The price of Merck's Januvia, a diabetes medicine, fell 20 percent, then rose to more than double the original price. ${ }^{214}$ So patients paid even more, and the Peruvian government lost tariff revenue-but corporate profits went up.

For developing countries, tariffs are a means of generating revenue that can fund public services like health care. Most medications procured by Peru's public health system are given free to patients, but the state lacks the funds to buy all it should. César Alva, president of La Victoria Association of People Affected by Tuberculosis, explains: "The state covers antiretrovirals and tuberculosis medications, but there's no treatment for the opportunistic infections we get because our defenses are low." Peru lost more than $\$ 10$ million annually in tax revenue for the tariff exemptions, but did not achieve the needed price reduction. By 2014 the cost of the antiretroviral drug atazanavir (Reyataz) was eating up fully half of Peru's budget for AIDS medicines. Peru was paying $\$ 10.50$ per pill, while the same pill cost $\$ 3.60$ in Brazil and as little as 50 cents on the international market. ${ }^{215}$ To look at it another way, a year's treatment was costing Peru $\$ 3,832$ per patient, while the Pan American Health Organization's Strategic Fund was obtaining generics for only $\$ 182$ per patient. ${ }^{216}$

The government contemplated issuing a compulsory license, earning it a spot on the US Trade Representative Watch List. After withstanding two years of US government threats, Peru's finance minister announced the country would continue paying the full cost as before. "The state could pay less," César Alva says, "but they choose to buy from a business that sells for a higher price. And that, for us, is incomprehensible." 
In the case of the pharmaceutical companies, the overly strict intellectual property regime (that abets price gouging) combines with the lax international tax regime (that abets massive tax avoidance), clearly victimizing the most vulnerable. The companies funnel superprofits from people living in poverty to wealthy shareholders and corporate executives, driving ever wider the gap between the richest and the rest.

\section{Unravel the stranglehold}

The example of pharmaceutical companies offers insight into a fair example of how certain elites have shaped the political and economic structures of today's world-and how those structures drive the inequality gap between rich and poor, between men and women, and between advanced economies and developing ones. The UN High-Level Panel report recognized, as Oxfam has long been saying, that the current system of biomedical R\&D based on monopoly protections through the IP system does not meet the health needs of millions around the world.

Campaigners have for many years sought to loosen the drug companies' stranglehold on policies and practices that affect access to medicines. To end the unequal playing field that benefits the wealthy and well-connected at our expense, we must now also focus on their damaging tax behavior. In the final chapter we turn to practical steps to end the rigged rules that allow large pharmaceutical companies to avoid paying their fair share. 


\section{Chapter 4: What we must do}

As the story of Tobeka Daki, the South African single mother with breast cancer, recounted at the beginning of this report makes clear, the first to lose when pharmaceutical companies dodge taxes, raise prices at will, and lean on government officials are patients, who face the horrendous choice of paying outrageous prices or suffering and often dying. Ordinary taxpayers, who must pay more to make up for what the companies avoid, also lose out. And so does the public at large, obliged to contend with underfunded and deficient public institutions.

Women are more likely than men to live in poverty. Aggressive tax avoidance by the pharmaceutical companies contributes to starving the budgets for public services, like health and education, which have an equalizing effect on society and tend to benefit women in particular. ${ }^{217}$ It forces governments to raise a greater proportion of their revenue from regressive taxes, which take a larger bite out of women's earnings, or to cut social investment. And it obliges women and girls to step into the breach when health care systems lack the wherewithal to care for the ill.

The problem of tax dodging extends beyond the four companies highlighted in this report; indeed, it extends beyond the pharmaceutical industry. Over the past 30 years, net profits posted by the world's largest corporations more than tripled in real terms, from $\$ 2$ trillion in 1980 to $\$ 7.2$ trillion by $2013 .{ }^{218}$ Meanwhile, effective corporate taxation fell by nearly onethird since 2000 , from 34 percent to 24 percent. ${ }^{219}$

The decline in corporate tax revenue results both from the race to the bottom in corporate tax rates and from aggressive tax avoidance strategies like those described in this report. The Financial Times recently calculated the enormous gap between the reported effective tax rate and what selected companies actually paid over the past three years. ${ }^{220}$ Johnson \& Johnson and Pfizer were included in the list of companies paying less than the reported effective tax rate that the Financial Times. Johnson \& Johnson's reported tax rate was 18 percent, yet the company paid only 14 percent; Pfizer's was 20 percent, yet it paid only 13 percent.

Recent research by tax economist Gabriel Zucman estimates that nearly 40 percent of all multinational corporate profits were artificially shifted to tax havens in 2015-one of the major drivers of declining corporate tax payments worldwide. ${ }^{221}$

Ensuring corporations pay their fair share to support the public institutions we all depend on is particularly important in developing countries, where corporate tax revenues make up twice as large a proportion of total tax revenues as in rich countries. ${ }^{222}$ Corporate taxes help pay for schools, hospitals, and roads, which are crucial for enhancing national welfare and reducing inequality, particularly between men and women-and are essential to the longterm health of companies like Abbott, Johnson \& Johnson, Merck, and Pfizer. And after all, these companies depend on government spending for public procurement, publicly funded research, public drug certification, and public protection of intellectual property-even the roads their employees drive on to work.

Scandalously, the poorer a country is, the more likely corporations will shift their profits out of it and into tax havens. ${ }^{223}$ Developing countries lose around $\$ 100$ billion annually as a result of corporate tax avoidance schemes. That is more than enough to pay for the health interventions needed to save the lives of six million children. ${ }^{224}$

The estimates we present of tax underpayments to developing countries and wealthy ones is certainly incomplete, and that should come as no surprise. Pharmaceutical companies do not make public the financial operations of their hundreds of subsidiaries. Requiring the 
companies to publish tax-relevant data on a country-by-country basis would allow authorities to pinpoint how much profit-shifting is actually taking place, as well as shed light on the legality of the companies' tax-avoidance schemes. The veil of secrecy must be lifted.

Yet, pharmaceutical company secrecy extends to all aspects of their business, including the cost of R\&D, medicine pricing, and clinical trial results. Moreover, companies have relied on the intellectual property system for monopoly protections that ensure large profits but without delivering the medicines needed for public health. Separating financing of R\&D from the price of the resulting product is critical for enhancing both innovation and access to medicines. As recommended by the UN High-Level Panel, countries should begin negotiation of a global R\&D convention that is based on this "delinkage."

Perhaps even more galling than the sophisticated tax-avoidance strategies we describe is the subversion of democratic politics by which the companies obtain favorable rules and regulations and give price gouging and tax dodging a veneer of legitimacy. By making millions of dollars in campaign donations, employing an army of lobbyists, and placing their own people in powerful government positions, these companies have effectively blocked government efforts to promote the public interest. This too must change.

Pharmaceutical corporations paint themselves as noble scientists leading the charge against disease. But their tax practices-raising prices and dodging taxes in order to deliver evergreater returns to rich shareholders and senior executives-offer prime examples of poor corporate behavior.

These corporations must choose the high road. Rather than engage in elaborate ruses to hide their profits, they must pay their taxes. Rather than charge the maximum imaginable for their products, they must be transparent about the cost of R\&D and price medicines at a level affordable to all who need them.

To its credit, Johnson \& Johnson is up-front about is obligations to pay tax, unlike the three other companies. In its corporate credo, the company pledges to be "good citizens" who are "responsible to the communities in which we live and work and to the world community as well." This includes a commitment to "bear our fair share of taxes."225

Johnson \& Johnson reaffirms its responsibility to pay its fair share in its Tax Policy Statement, which covers compliance, tax planning, and risk, and the corporation's relationship with government tax authorities. The company states it has a "low tolerance for tax risk" and commits to "reject planning opportunities that are not in line with our values or are inconsistent with our reputation." 226

This is a laudable commitment-but Johnson \& Johnson is not transparent enough for outside observers to assess whether it is following through. The financial information that is publicly available demonstrates a significant mismatch between the corporation's global profit margins and the profit it earns in individual countries. By Oxfam's estimates, Johnson \& Johnson may be underpaying the most tax of the four companies we studied, in both rich and poor countries. Johnson \& Johnson must do more to lead the way in accord with its own credo and the values it espouses.

Other major corporations have taken positive steps forward on taxes and transparency. Vodafone, for example, has committed to publish its full country-by-country report from 2019 onward, building on the comprehensive reporting of taxes and related data on a country-bycountry basis that the company has been publishing for several years now. ${ }^{227}$ Other corporations, like AngloAmerican, Unilever, and SABMiller (prior to its merger with AB Inbev) publish detailed tax strategies and report some tax-related information on a regional or percountry basis. ${ }^{228}$ 
Earlier this year, the B Team, a coalition of forward-looking business leaders, announced a new set of principles and commitments on corporate tax. Despite some weaknesses, The B Team initiative raises the bar on what constitutes responsible corporate tax behavior. ${ }^{229}$ The principles require signatory companies, which currently include Allianz, Unilever, and Vodafone Group, to make real changes. For example, companies commit to publish and report on their tax strategy; to not abuse tax havens; to provide an explanation for any subsidiaries located in low-tax jurisdictions; and to be transparent about all the entities they own around the world. ${ }^{230}$

These commitments go well beyond what is legally required of companies. They set a new standard for corporations that claim to operate responsibly-claims that ring hollow if businesses do not pay their fair share of taxes and are not transparent about their business.

Corporate investors are also taking note. The Principles for Responsible Investment (PRI), whose signatories now hold more than $\$ 70$ trillion in assets under management, have published two guides to encourage investors to engage with corporations on tax issues, including addressing the risks of aggressive tax planning and being more open and transparent. ${ }^{231}$

As Oxfam, along with ActionAid and Christian Aid, laid out in a blueprint for responsible corporate tax behavior called Getting to Good: Towards Responsible Corporate Tax Behaviour, tax behavior should be shaped by values, reflecting a company's duty to contribute to the public good. A tax-responsible company is transparent about its business structure and operations, its tax affairs, and its tax decision-making. It assesses and reports publicly on the fiscal, economic, and social impacts of its tax-related decisions and practices. And it takes progressive and measurable steps to improve the sustainable development impact of its tax behavior. ${ }^{232}$

Governments, too, must refrain from engaging in a race to the bottom on taxation and must ensure their citizens can access important budget information and influence tax revenue spending decisions. The BEPS process initiated by the OECD and the G20 only scratched the surface of the global scourge of tax havens and dodgy schemes. Much more serious coordinated multilateral action is essential to unravel the harmful practices that abet aggressive tax avoidance by rich corporations, and to ensure no country undercuts its neighbors with wasteful and unproductive corporate tax breaks.

Governments must also require transparency from pharmaceutical companies on the cost of R\&D, as well as patent registration information, medicine pricing, and results of clinical trials. To reduce prices of medicines, governments should use the flexibilities enshrined in the TRIPS agreement, such as compulsory licensing. Rich country governments-especially the US-should refrain from exerting pressure to stop countries from using these flexibilities and should stop using trade agreements as a weapon.

Corporations and governments share the blame for our broken and dysfunctional tax system that privileges multinational corporations and the wealthy over everyone else.

Pharmaceutical corporations should not be able to cloak their financial and tax affairs in secrecy, dodge tax with impunity, and use their immense political power to bend their rules in their favor. Governments must stop the dangerous race to the bottom on taxes, and they must commit to investing in the public services their citizens-particularly women and girlsneed.

We can all play a role in holding the pharmaceutical corporations to account. Here are our recommendations: 
Join Oxfam to demand that drug companies stop cheating women and girls out of the chance to beat poverty.

\section{For governments}

On tax, governments should:

- Require that all large multinational companies adhere to a standard of full and effective transparency. This includes:

- Mandating and implementing public country-by-country financial reporting for all large multinational companies.

- Establishing a centralized public registry of beneficial ownership information for all companies.

- Require that large multinational companies pay a fair, effective tax rate on their profits in every country where they operate. This includes:

- Achieving a global consensus to halt the worldwide race to the bottom on corporate tax.

- Agreeing on a minimum effective tax for corporate profits.

- Mandating rules to discourage profit-shifting.

- Adopting a second generation of international tax reforms to address highly mobile assets, including intellectual property and other intangibles. These reforms should consider taxing companies on their global profits and apportioning revenue according to value creation and economic activity.

- Putting an end to harmful tax practices, like patent boxes.

- Ceasing to offer discretionary tax incentives, and subjecting all new incentives to rigorous economic and risk assessments (including considering their contribution to global and regional races to the bottom). All incentives should be objective, transparent, and regularly reviewed, and, when evidence that they are effective is lacking, they should be phased out.

- Joining multilateral efforts to identify tax havens, using a process that is ambitious, transparent, objective, and free from political interference.

- Ensure that all global tax reforms allow developing countries to participate on an equal basis.

In addition, the US should:

- Tax profits derived from foreign operations at the same rate as those derived from domestic operations.

- Adopt new measures to prevent US companies from "inverting" into foreign companies to avoid US tax on foreign profits, for example by treating all companies controlled from the United States or at least 50 percent-owned by Americans as US companies.

On health, governments should:

- Require companies to disclose the cost of R\&D, production, and marketing of medicines before approving product registration.

- Use the legal rights in the WTO's Agreement on Trade-Related Intellectual Property (known as the TRIPS agreement) to ensure access to medicines within their country, and wealthy countries must refrain from pressuring other countries to stop them using these legal means to ensure access to medicines for their citizens.

- Start negotiations for a global convention on R\&D that explores delinking the funding of R\&D from the price of resulting products.

- Do not use free trade agreements to restrict access to medicines including through stricter intellectual property rules.

- Ensure that the UN High-Level Panel's recommendations are carried out.

- Invest in public health services that are free for patients at the point of use. 


\section{On gender, governments should:}

- Systematically monitor and assess the impact on women and girls of tax policies, which will require improving the collection of gender-disaggregated data in national and local accounting systems and implementing gender budgeting.

- Ensure the voices of poor and marginalized women are heard when decisions on taxation are made at the local, national, and international levels. This action includes:

- Making tax reforms open to citizen participation, especially to women's participation.

- Implementing gender budgeting to assess the impact of spending decisions on women and girls.

- Allocating spending in ways that promote gender equality.

- Including women's rights groups in policymaking spaces.

- Addressing gender inequality in political representation and leadership.

\section{For companies}

On tax, companies should:

\section{Be more transparent by:}

- Publishing all information necessary for citizens to measure and understand the company's tax practices.

- Publishing the following information, in every country where they operate:

- List of all subsidiaries, including a brief description of the nature of their business and commercial activities.

- Number of employees working on a full-time basis.

- Tangible and intangible assets (used in business operations).

- Profit before income tax.

- Income tax accrued and paid.

- Statement reconciling the statutory and the effective tax rate (ETR) and the ETR and cash tax paid, including an explanation for any discrepancies.

- Public subsidies received, including but not limited to a description of preferential tax rules, incentives, or treatment that apply to the companies or entities/branches in the jurisdiction.

- Publishing information that explains companies' overall effective tax rate and explains any gaps between the ETR and the statutory rate, as well as any gaps between ETR and cash tax paid.

- Being transparent about the entities companies own around the world, who owns them, and who benefits from them.

- This includes:

- An overview of their group structure and a list of all entities and subsidiaries in all jurisdictions, with ownership information and a brief explanation of the type and geographic scope of activities.

- A public explanation for subsidiaries, branches, and joint ventures operating in low-tax jurisdictions.

- Publishing a tax policy document that is board-approved, applies to all local tax practices in all jurisdictions and to all subsidiaries and entities.

- This tax policy document should include:

- A statement affirming the role of corporate taxation to support necessary investment in education, health care, infrastructure, or other public services essential for lifting people out of poverty.

- A statement that expresses the companies' commitment to avoid aggressive tax-planning practices that may unjustly deny governments resources necessary to uphold their human rights obligations to their citizens. 
- A statement affirming that the companies' business strategy drives its tax planning, and not vice versa.

- A description of the level of risk the board considers acceptable with respect to tax, including a description of current tax risk factors.

- A description of the approach that the tax department is expected to take when dealing with unclear tax rules.

- A list of voluntary standards or principles beyond legal compliance on responsible corporate tax behavior that the company has committed to follow, such as the B Team's responsible tax principles.

\section{Act responsibly on tax by:}

- Aligning tax payments with places where the company creates value, employs workforce, and makes use public services.

- Publicly committing to pay taxes on profits according to where value is created within the normal course of commercial activity, and publicly committing to not artificially shifting profits to low-tax jurisdictions.

- Publicly demonstrating steps to progressively align economic activities and tax liabilities.

- Publicly committing to shut down subsidiaries in low-tax jurisdictions when there is no economic substance or business purpose independent of tax considerations.

- Disclosing the size and key details of any "uncertain tax positions" that a revenue authority is at significant risk of challenging.

- Assessing and publicly reporting on the fiscal, economic, and social impact of taxrelated decisions and practices in a manner that is accessible and comprehensive.

- This assessment should include the impact on the companies, on the revenue due to governments, and, in line with corporate responsibility to respect human rights, on the human rights of employees, customers, and communities where the companies have operations. These reports should note any particular impacts on gender and women's rights.

\section{Use their influence responsibly by:}

- Using their power and influence in all jurisdictions in which they operate to shape a more equitable tax system to further sustainable and inclusive growth.

- This includes publicly committing to:

- Advocate for stronger international cooperation in tax matters, and to stop the dangerous "race to the bottom" on corporate tax.

- Support national and international policy and regulatory efforts requiring companies to publish country-by-country reporting of tax and financial information.

- Support policy reforms to prevent abusive tax practices in jurisdictions regarded as tax havens.

- Support policy reforms to require the full disclosure of beneficial ownership information.

- Publishing all submissions and details of all meetings with lawmakers, regulators, government officials, and intergovernmental bodies regarding changes to national or international tax rules, including disclosing the positions they take to influence public policy.

- Publicly disclosing all contributions made to political candidates, policymakers, trade associations, think tanks, coalitions, and other political entities to influence tax policy in the US and abroad.

- Publicly committing to align financial contributions and private advocacy with public positioning and messaging on tax policy issues.

- This includes publicly committing to: 
- Adopt a consistent stance on tax policy across the jurisdictions in which the companies do business, particularly in both developing and advanced economies.

- Publicly oppose or disengage from trade or industry associations that take a public position that contravenes companies' efforts on fiscal justice, gender equality, or access to medicines.

- Publicly committing to cooperate with tax authorities of jurisdictions where companies have business activities or intend to set up operations, by following established procedures and channels for all dealings with tax authorities and government officials, and by providing information requested in an open and transparent way.

- Publicly committing to proactively boost the administrative capacity of governments in developing countries, particularly with respect to tax.

\section{On gender, companies should:}

- Publicly sign on to the UN's Women's Empowerment Principles to demonstrate commitment to gender equality.

- Publish a position statement that commits to working to improve global access to health and/or medicines with an explicit mention of women's and girls' rights and gender equality.

- Publicly commit to ensure the full and equal participation of women in clinical research and trials.

- Implement policies and practices to address the objectification of women in advertising and to promote gender-sensitive product and service development and gender-sensitive marketing.

- Publicly demonstrate a commitment to advance women employees, including in senior leadership positions.

- Publicly demonstrate a commitment to ensure payment of a fair and living wage to all employees, including an express commitment to equal pay for work of equal value.

- This includes conducting and disclosing an annual compensation review to evaluate gender-based variations in pay, disaggregated by employment level, and where a gender pay gap is identified, publicly disclosing a strategy and/or steps taken to close the gap.

- Provide relevant and practical gender awareness training to all staff on gender equality; sexual harassment, abuse, and exploitation; human rights; diversity and inclusion; and antidiscrimination.

- Implement policies and practices to prevent, respond to, and remedy an unsafe workplace, gender-based violence, and harassment.

- Establish and publicly evaluate complaints/grievance mechanisms that are transparent, fair, rights-based, and accessible to both women and men.

\section{On medicines, companies should:}

- Publicly declare actual spending on R\&D, production, and marketing of medicines and commit to full transparency on medicine prices and patent information.

- Register all clinical trials, completed or not, with positive, negative, or neutral results on a public site via the WHO International Clinical Trials Registry Platform.

- Publicly commit to stop pushing individually or through trade associations for "TRIPS plus" provisions in free trade agreements.

- Publicly commit to pricing medicines so that they are affordable to all health systems and patients.

- Publicly commit to explore the delinking model for R\&D where financing research and development are not dependent on charging high prices.

- Publicly commit to not pressure governments that seek to use legal measures (for example, compulsory licensing) to make medicines affordable in their 
countries, whether individually or through pharmaceutical trade associations or other entities.

- Publicly declare support for the UN High Level Panel on Access to Medicines and its recommendations.

\section{For investors}

Investors should:

- Engage companies on their tax policies and practices.

$\circ$ This engagement can include dialogues, roundtables, collaborative activities, investor statements, and resolutions when appropriate.

- Ask companies to adopt more transparency around their corporate tax practices that would impact their tax risk, as detailed in PRI's Evaluating and Engaging on Corporate Tax Transparency: An Investor Guide (2018) and Engagement Guidance on Corporate Tax Responsibility (2017).

- Engage companies on the disclosure of their actual spending on R\&D, production, marketing, and pricing of their medicines, as well as their pricing practices.

- Engage companies on their lobbying disclosure.

- Communicate that responsible tax management is an aspect of sustainable profitability.

- Signal that transparency around corporate tax practices is evidence of strong and responsible corporate governance.

- Assess the impact of companies on economic and gender inequality when evaluating company environmental, social, and governance (ESG) performance. 


\section{ANNEX: TAX RESEARCH METHODOLOGY}

Oxfam analyzed the corporations' 10-K filings with the US Securities and Exchange Commission (SEC). These filings contain financial statements for the companies' global operations with limited geographical breakdowns. The 10-K data was used to calculate the global profit margin, as the pretax profit divided by sales.

The 10-K reports also include a list of the groups' subsidiaries, with their names and host countries. The Orbis database ${ }^{233}$ was consulted to identify the countries where publicly available information may be found and to spot individual subsidiaries of interest based on extraordinary revenues, profits, or tax paid. The research was narrowed to 19 countries based primarily on the public availability of data; these countries were then divided into three groups: tax havens, developing countries, advanced countries. The list of tax havens comes from Oxfam's Tax Battles report: ${ }^{234}$ the categorization of developing and advanced economies follows the International Monetary Fund (IMF) classifications.

\begin{tabular}{|l|l|l|}
\hline \multicolumn{3}{|c|}{ Countries analyzed } \\
\hline Tax havens & Developing countries & Advanced economies \\
\hline Belgium (see box below) & Chile & Australia \\
\hline Ireland & Colombia & Denmark \\
\hline Netherlands & Ecuador & France \\
\hline Singapore & India & Germany \\
\hline \multirow{5}{*}{} & Pakistan & Italy \\
\cline { 2 - 4 } & Peru & New Zealand \\
\cline { 2 - 3 } & Thailand & Spain \\
\cline { 2 - 3 } & & United Kingdom \\
\hline
\end{tabular}

For all 19 countries, Oxfam searched national company registries and gleaned the financial statements of all subsidiaries of the four pharmaceutical companies that could be found. Data on revenue (sales), pretax profit, and tax paid were extracted from these financial statements. For the four tax havens only, that data was complemented with information from the Orbis database. Orbis data was not used for the advanced economies because it was not necessary; many financial statements are in public registries. Orbis data was not used for developing countries because it proved to be of dubious quality; many entries seemed to be incorrect by orders of magnitude, and others did not match what was found in financial statements.

The United States was also included in Oxfam's analysis in a category of its own, as the home country of the four pharmaceutical companies. US revenue, profit, and tax data came from the $10-\mathrm{K}$ reports.

Three years of data $(2013,2014$, and 2015) were used whenever available to smooth out exceptional financial results. For each subsidiary with multiple years of data available, each variable (revenue, profit, tax) was averaged over the available years.

All data was converted from local currency into US dollars using the spot rate on the last day of the relevant year as posted on www.oanda.com. 


\begin{tabular}{|c|c|c|c|c|c|c|}
\hline \multicolumn{7}{|c|}{ Drug company subsidiaries } \\
\hline & \multicolumn{3}{|c|}{$\begin{array}{l}\text { Number of subsidiaries listed } \\
\text { (in countries analyzed) }\end{array}$} & \multicolumn{3}{|c|}{ Number of subsidiaries analyzed } \\
\hline & Tax havens & $\begin{array}{l}\text { Developing } \\
\text { countries }\end{array}$ & $\begin{array}{l}\text { Advanced } \\
\text { economies }\end{array}$ & Tax havens & $\begin{array}{l}\text { Developing } \\
\text { countries }\end{array}$ & $\begin{array}{l}\text { Advanced } \\
\text { economies }\end{array}$ \\
\hline Abbott & $\begin{array}{r}96 \\
(42)\end{array}$ & $\begin{array}{l}141 \\
(52)\end{array}$ & $\begin{array}{r}98 \\
(66)\end{array}$ & 19 & 16 & 53 \\
\hline J\&J & $\begin{array}{r}68 \\
(45)\end{array}$ & $\begin{array}{l}48 \\
(9)\end{array}$ & $\begin{array}{r}77 \\
(47)\end{array}$ & 26 & 7 & 54 \\
\hline Merck & $\begin{array}{l}129 \\
(80)\end{array}$ & $\begin{array}{l}116 \\
(19)\end{array}$ & $\begin{array}{r}152 \\
(97)\end{array}$ & 20 & 13 & 63 \\
\hline Pfizer & $\begin{array}{r}191 \\
(114)\end{array}$ & $\begin{array}{l}117 \\
(24)\end{array}$ & $\begin{array}{l}148 \\
(92)\end{array}$ & 19 & 17 & 52 \\
\hline TOTAL & $\begin{array}{r}484 \\
(281)\end{array}$ & $\begin{array}{r}422 \\
(104)\end{array}$ & $\begin{array}{r}475 \\
(302)\end{array}$ & 84 & 53 & 222 \\
\hline
\end{tabular}

Source: $10-\mathrm{K}$ filings as of December 31,2015 . The list of subsidiaries in $10-\mathrm{K}$ reports is not necessarily exhaustive.

Each company's profit margin was calculated in each country by adding up the profits of all the company's subsidiaries in that country, and then dividing that sum by the sum of all the company's revenues. These profit margins are therefore unconsolidated figures: they do not exclude the double-counting inherent to intragroup transactions within a country. (For example, if subsidiary A in country 1 sells goods to subsidiary $B$ in country 1 , which resells the goods partly to consumers in country 1 and partly to subsidiary $C$ in country 2 , both the sale and related profit are counted twice to compute country 1's profit margin.) ${ }^{235}$

This gross simplification, solely driven by lack of data consolidated at the country level, can significantly alter results. The country-by-country reports that companies provide to tax authorities-and that Oxfam calls on them to publish-contain the consolidated data needed for a better assessment of country-specific profit margins. Note, however, that for the United States the 10-K reports do consolidate profits and taxes, and count revenue as final sales to unaffiliated US-based customers (including sales from non-US subsidiaries).

To generate an allocation of profit worldwide, the 10-K reports were consulted and each pharma company's consolidated global profit margin was calculated.

\begin{tabular}{|l|r|l|l|r|}
\hline \multicolumn{7}{|c|}{ Global average profit margin (percent) } \\
\hline Year & Abbott & $\begin{array}{l}\text { Johnson \& } \\
\text { Johnson }\end{array}$ & Merck & Pfizer \\
\hline 2013 & 10 & 22 & 13 & 30 \\
\hline 2014 & 12 & 28 & $14^{*}$ & 25 \\
\hline 2015 & 16 & 27 & 14 & 18 \\
\hline
\end{tabular}

* Merck's reported profit margin for 2014 is 41 percent; for this analysis it was adjusted downwards to exclude the proceeds of the sale of a subsidiary. 
Using the information from financial statements obtained with the help of local researchers, Oxfam was able to map out the average profit margins per jurisdiction. ${ }^{236}$ The total profits of all subsidiaries in a country were divided by the total turnover. ${ }^{237}$

To calculate the tax shortfall in each country, each company's revenues in that country were multiplied by the global profit margin to obtain the counterfactual profit that companies would make in that country if profit margins were uniform all over the world. The country's statutory tax rate was then applied to that counterfactual profit to obtain the counterfactual tax owed in that country. Finally, the actual tax paid in that country was subtracted from the counterfactual tax owed to obtain the tax shortfall.

In addition to comparing profit margins and tax shortfalls across countries, Oxfam qualitatively analyzed the financial statements of selected subsidiaries that exhibited exceptional profit margins or effective tax rates.

The analysis did reveal some anomalies. For example, in Peru and Spain companies paid more tax than our counterfactual estimate. In both cases, a single subsidiary in each market (Abbott's Farmindustria in Peru, and Pfizer's Wyeth Farma in Spain) reported profit margins much higher than the global average, driving the results for the country as a whole. Other countries, like the UK, also had individual outliers. Nonetheless, the pattern of low profits and tax underpayment in all jurisdictions other than tax havens was largely consistent.

\section{External review}

To better understand the ways in which drug companies arrange their financial and tax operations, Oxfam spoke with current and former executives from the top 10 pharmaceutical and accounting firms on the condition of anonymity, as well as other tax experts. These executives and experts described the carefully designed corporate structures, which systematically minimize the amount of profit that stays in developing countries. The results of Oxfam's analysis were shared with these sources to help review our assumptions and research methodology.

Groups and individuals with whom we consulted include:

- Richard Phillips, senior policy analyst, Institute on Taxation and Economic Policy

- Zorka Milin, senior legal advisor, Global Witness

- A current head of tax for a global 100 company, who wishes to remain anonymous

- An attorney expert in global patent ownership, formerly at a major multinational pharmaceutical company, who wishes to remain anonymous

- An international nongovernmental organization working on tax justice

We also received research assistance from two international corporate tax experts:

- Tommaso Faccio, head of secretariat of the Independent Commission for the Reform of International Corporate Taxation (ICRICT) and a lecturer in accounting at Nottingham University Business School (UK), who until July 2014 was a transfer pricing senior manager in the Deloitte LLP international tax team and who has significant experience advising multinationals on complex international tax issues, particularly in the area of transfer pricing and permanent establishment

- Javier Pereira, who has worked on tax issues with a number of development organizations, including Oxfam and ActionAid

\section{How to interpret the results}

None of the results are precise because they exclude subsidiaries for which publicly available data was not found and because the data is not consolidated at the country level 
(except for the United States). Both of these limitations could be resolved if companies published the country-by-country reports they provide to tax authorities.

Oxfam's analysis reveals that profit margins in tax havens are higher than in both advanced and developing countries. That difference is statistically significant; that is, it reflects a systematic pattern and cannot be attributed to chance. Although the pattern could be caused by other factors than tax, no other factor is shared among the four tax havens (Belgium, Ireland, the Netherlands, and Singapore) that is not also shared by the advanced countries in our sample, which served as the control group.

\section{Is Belgium a tax haven?}

Although Belgium did not feature in Oxfam's list of biggest corporate tax havens in 2016 owing to methodological reasons, Oxfam did consider Belgium a corporate tax haven in the period covered by this research. ${ }^{238}$ This consideration was mainly a consequence of Belgium's notional interest deduction system, a tax incentive that allowed companies to deduct a fictitious interest deduction on the basis of shareholder equity. The system was massively abused by multinational companies, setting up internal banks in Belgium and providing large intragroup loans to subsidiaries elsewhere. Apart from the notional interest deduction, Belgium also offered a range of other advantages to multinationals, such the excess profit rulings and the patent box. ${ }^{239}$

Following severe international pressure, Belgium reformed both the notional interest deduction and the patent box. From 2018 on, the notional interest deduction won't be calculated on the total stock of equity but only on incremental equity over the preceding five years. This change, combined with newly announced anti-abuse measures, will strongly limit the abuse of the system. However, pharma companies looking to reduce their tax bills still have many opportunities to do so in Belgium, especially by using the country's reformed patent box. The so-called innovation income deduction offers companies such as Janssen Pharmaceutica, a Belgian company that is part of Johnson \& Johnson, a massive deduction of up to 85 percent on its profits derived from R\&D. Although the European Commission notes that research shows very little evidence of patent boxes stimulating innovation, more and more countries are offering these incentives to attract investments. ${ }^{240}$ This adoption of incentives increases tax competition between governments within and beyond the $E U$, and it accelerates the race to the bottom.

The higher profit margins in tax havens are consistent with profit-shifting to tax havens. Tax avoidance consists of shifting profits across countries so that they do not reflect real business activities, and thus misalign tax payments. One indicator of real business activity that can be measured is sales. To provide an assessment of the extent of tax avoidance, Oxfam compared actual tax paid to the tax owed if global profits were allocated to each country based on the total sales of the subsidiaries located in that country (this figure includes exports from subsidiaries based in the given country).

That estimate of tax "shortfall" is admittedly a gross simplification, as sales are a very crude proxy for economic activity. Moreover, there are many factors explaining variations of profit margins across countries that are unrelated to tax, such as country-specific macroeconomic policies or pharmaceutical regulations.

Oxfam's qualitative analysis of individual financial statements confirms that the four tax havens in the sample host relatively more holding subsidiaries, subsidiaries offering financial, management or other services to other subsidiaries, and subsidiaries centralizing trade among other subsidiaries-all activities that offer opportunities for profit-shifting. 
While such activities are indicative of tax avoidance, as are significant variations of profit margins between tax havens and other countries, they do not represent a conclusive proof, which only in-depth tax audits could produce.

\footnotetext{
${ }^{1}$ In 2013, Abbott spun off its proprietary R\&D-based pharmaceutical business into a separate corporation named Abbvie, while Abbott focused on medical devices, diagnostics, nutrition, and branded generic pharmaceuticals.See "Abbott Completes Separation of Research-Based Pharmaceuticals Business," PR Newswire, January 2, 2013, https://www.prnewswire.com/news-releases/abbott-completes-separation-ofresearch-based-pharmaceuticals-business-185406542.html.Abbott does not sell pharmaceuticals in the US, although Abbott does continue to sell pharmaceutical products as a major part of its global business. While Abbott, like Johnson \& Johnson, provides a variety of health care services and products, this report refers to Abbott as a pharmaceutical or drug company. In addition, this report focuses on the US-based pharmaceutical company Merck and Company, Inc., sometimes known as Merck Sharp \& Dohme (MSD) outside the US, not the German-based pharmaceutical company Merck KGaA.

${ }^{2}$ Oxfam identified 1,381 subsidiaries of the four companies and found publicly available data for 359 of them: 53 in developing countries, 222 in advanced economies, and 84 in tax havens. The developing countries examined were Chile, Colombia, Ecuador, India, Pakistan, Peru, and Thailand; the wealthy countries were Australia, Denmark, France, Germany, Italy, New Zealand, Spain, and the UK; and the tax havens were Belgium, Ireland, the Netherlands, and Singapore.

${ }^{3}$ Global profit rates are derived from annual 10-K filings with the US Securities and Exchange Commission (SEC). Oxfam calculated the profit margins in developing countries, advanced economies, and tax havens by taking the profits of all subsidiaries per jurisdiction divided by total turnover. See the annex, "Tax Research Methodology," for more information.

${ }^{4}$ Oxfam was unable to obtain tax data in the most secretive tax havens (e.g., Bermuda, and theCayman Islands) and instead examined data from those countries that are tax havens but have some actual manufacturing or research facilities. These countries seem to be used by the companies as "pivots," where profits are allocated before being allocated yet again to the more secretive jurisdictions.
}

${ }^{5}$ Institute on Taxation and Economic Policy (ITEP), "Offshore Shell Games 2017," October 17, 2017, https://itep.org/offshoreshellgames2017/.

${ }^{6}$ Ibid.

${ }^{7}$ Thomas Tørsløv, Ludvig Wier, and Gabriel Zucman, "The Missing Profits of Nations," VoxEU.org/CEPR Policy Portal, July 23, 2018, https://voxeu.org/article/missing-profits-nations.

${ }^{8}$ These figures are estimates that represent the difference between the taxes the companies say they actually pay and what they would pay under a system of global apportionment that assumes profit margins are equal across countries. See the annex, "Tax Research Methodology," for more information.

${ }^{9}$ Centers for Disease Control and Prevention (CDC), "Genital HPV Infection-Fact Sheet," Human Papillomavirus (HPV), https://www.cdc.gov/std/hpv/stdfact-hpv.htm.

${ }^{10}$ World Health Organization (WHO), "Human Papillomavirus (HPV) and Cervical Cancer," fact sheet, http://www.who.int/news-room/fact-sheets/detail/human-papillomavirus-(hpv)-and-cervical-cancer.

11 Ibid.

${ }^{12}$ Union for International Cancer Control (UICC), "UICC Members Respond to the Global Call to Action to Eliminate Cervical Cancer," June 27, 2018, https://www.uicc.org/uicc-members-respond-global-call-actioneliminate-cervical-cancer?utm_source=Capacity+building+list\&utm_campaign=56de8d2e48- .

${ }^{13}$ HPV Information Centre, http://www.hpvcentre.net/datastatistics.php. For statistics, select Module: "M2. Disease burden estimates"; Topic: "Cervical cancer"; Indicator: "Number of deaths."

${ }^{14}$ Centers for Disease Control and Prevention (CDC), "HPV Vaccines: Vaccinating Your Preteen or Teen," Human Papillomavirus (HPV), https://www.cdc.gov/hpv/parents/vaccine.html.

${ }^{15}$ The CDC recommends two doses of the vaccine: CDC, "HPC Vaccine Information for Young Women," https://www.cdc.gov/std/hpv/stdfact-hpv-vaccine-young-women.htm. Oxfam calculated these estimates by taking the estimated price paid for these vaccines in each country and multiplying by two doses. We then divided the estimated tax loss per each country by the price for two doses. Thailand price sources: https://www.thaitravelclinic.com/cost.html; Latin American countries' price sources: prices from PAHO, https://www.paho.org/hq/index.php?option=com_docman\&task=doc_download\&gid=43314\&ltemid=270\&lang=en ; Pakistan/India, GAVI price of $\$ 4.50$ per dose, https://www.unicef.org/supply/files/2018_03_08_HPV_.pdf. 
${ }^{16} \$ 73,780,584 / \$ 9=8,197,843$. We calculated the number of children born per year using the World Bank's crude birth rate and population figures for 2016: World Bank, "Birth Rate, Crude (Per 1,000 People),"

https://data.worldbank.org/indicator/SP.DYN.CBRT.IN?view=chart; and World Bank, "Population, Total," (data for 1960 and 2017), https://data.worldbank.org/indicator/SP.POP.TOTL. We divided in half for the number of girls born per year. Thus, our formula was: population $/ 1,000 \mathrm{x}$ birth rate $=$ children born per year $/ 2=$ girls born per year. Our results gave us 12,588,235 girls born each year in India and 355,783 in Thailand.

${ }^{17}$ HPV Information Centre, http://www.hpvcentre.net/datastatistics.php. For statistics, select Module: "M2. Disease burden estimates"; Topic: "Cervical cancer"; Indicator: "Number of deaths."

${ }^{18}$ Calculations made as explained in note 3. See the annex, "Tax Research Methodology," for more information.

${ }^{19}$ Oxfam calculations are based on data from the Center for Responsive Politics, "Industry Profile: Summary, 2017," OpenSecrets.org, https://www.opensecrets.org/lobby/indusclient.php?id=h04\&year=2017.

${ }^{20}$ Lighthizer's firm was Skadden, Arps, Slate, Meagher \& Flom LLP.

${ }^{21}$ Center for Responsive Politics, "Industry Profile: Summary, 2017."

22 Ibid. The proportion of "revolvers"- the term for former government officials turned lobbyists and vice versaworking for the pharmaceutical industry has held steady at about 60 percent since 2010 . See Center for Responsive Politics, "Lobbyists Representing Pharmaceutical Research \& Manufacturers of America, 2017," OpenSecrets.org, https://www.opensecrets.org/lobby/clientlbs.php?id=D000000504\&year=2017.

${ }^{23}$ Johnson \& Johnson, Pfizer, and Merck are members of PhRMA. An executive vice president from Johnson \& Johnson and the board chairs and CEOs of both Merck and Pfizer sit on PhRMA's board of directors. PhRMA, "Our Leadership," https://www.phrma.org/about/our-leadership. Abbott is not a member of PhRMA.

${ }^{24}$ Oxfam calculations are based on data from Federal Elections Commission filings compiled by the Center for Responsive Politics (https://www.opensecrets.org). Political action committees pool campaign contributions from members and donate those funds to campaign for or against candidates, ballot initiatives, or legislation.

25 "Las presiones internacionales contra Colombia por su política de precios de los medicamentos," Contamos, March 26, 2018, http://contamos.com.co/noticias/las-presiones-internacionales-contra-colombia-por-su-politicade-precios-de-medicamentos/; Inside US Trade, "Colombia To Reduce Price Of Swiss Cancer Drug In Lieu Of Compulsory License," June 16, 2016, https://insidetrade.com/daily-news/colombia-reduce-price-swiss-cancerdrug-lieu-compulsory-license, Inside US Trade, "Lighthizer outlines list of actions Colombia must take ahead of OECD accession," February 26, 2018, https://insidetrade.com/daily-news/lighthizer-outlines-list-actions-colombiamust-take-ahead-oecd-accession.

${ }^{26}$ Ibid. The International Alliance of Patients' Organizations (IAPO) 2014 budget of $\$ 3.38$ million included $\$ 100,000$ from Johnson \& Johnson, $\$ 60,000$ from Pfizer, and $\$ 43,000$ from Merck. On IAPO, see https://www.iapo.org.uk/. The companies fund similar patients groups in wealthy countries. See Emily Kopp, Sydney Lupkin, and Elizabeth Lucas, "Patient Advocacy Groups Take in Millions from Drugmakers: Is There a Payback?," Kaiser Health News (KHN), April 6, 2018, https://khn.org/news/patient-advocacy-groups-take-inmillions-from-drugmakers-is-there-a-payback/.

${ }^{27}$ US Government Accountability Office (GAO), "Drug Industry: Profits, Research and Development Spending, and Merger and Acquisition Deals," GAO-18-40 (2017), 16.

${ }^{28}$ Sarah Knapton, "First New Antibiotic in 30 Years Discovered in Major Breakthrough," Telegraph, January 7 , 2016, https://www.telegraph.co.uk/science/2016/03/14/first-new-antibiotic-in-30-years-discovered-in-majorbreakthroug/.

${ }^{29}$ William Lazonick, Matt Hopkins, Ken Jacobson, Mustafa Erdem Sakinç, and Öner Tulum, "US Pharma's Financialized Business Model," Institute for New Economic Thinking Working Paper 60 (July 13, 2017), 4, https://www.ineteconomics.org/uploads/papers/WP_60-Lazonick-et-al-US-Pharma-Business-Model.pdf. Stock buybacks boost share prices as well as CEO compensation linked to share price.

${ }^{30}$ US House of Representatives, Committee on Oversight and Government Reform, "Skyrocketing Drug Prices: Year One of the Trump Administration," Democratic Staff Report, May 11, 2018, 2, https://democratsoversight.house.gov/sites/democrats.oversight.house.gov/files/Skyrocketing\%20Drug\%20PricesYear\%200ne\%20of\%20the\%20Trump\%20Administration.pdf.

${ }^{31}$ Ibid., 5.

32 Jonathan D. Rockoff, "How Pfizer Set the Cost of Its New Drug at $\$ 9,850$ a Month," Wall Street Journal, December 9, 2015, https://www.wsj.com/articles/the-art-of-setting-a-drug-price-144962808. 
${ }^{33}$ Maurie Backman, "This Is the No. 1 Reason Americans File for Bankruptcy," USA Today, May 5, 2017, https://eu.usatoday.com/story/money/personalfinance/2017/05/05/this-is-the-no-1-reason-americans-file-forbankruptcy/101148136/.

${ }^{34}$ Dzintars Gotham, Joseph Fortunak, Anton Pozniak, Saye Khoo, Graham Cooke, Frederick E. Nytko III, and Andrew Hill, "Estimated Generic Prices for Novel Treatments for Drug-Resistant Tuberculosis," Journal of Antimicrobial Chemotherapy 72, no. 4 (2017): 1243-52, https://academic.oup.com/jac/article/72/4/1243/2884272.

${ }^{35}$ Report of the UN Secretary-General's High-Level Panel on Access to Medicines (2016), http://www.unsgaccessmeds.org/final-report/.

${ }^{36}$ Oxfam, High-Priced Medicines and Lack of Needs-Driven Innovation: A Global Crisis That Fuels Inequality (2017), https://www.oxfam.org/sites/www.oxfam.org/files/file_attachments/ib-high-priced-medicines-innovation220917-en.pdf.

${ }^{37}$ Equilar and New York Times, "The 10 Highest-Paid CEOs in 2017," Equilar.com, May 25, 2018, http://www.equilar.com/reports/56-equilar-new-york-times-highest-paid-ceos-2018.html, based on the annual Equilar 200 studies.

${ }^{38}$ Data from S\&P Global Market Intelligence and Equilar. See Matt Krantz, "Drug Prices Are High. So Are the CEOs' Pay," USA Today, August 26, 2016, https://www.usatoday.com/story/money/markets/2016/08/26/drugmoney-pharma-ceos-paid-71-more/89369152/.

${ }^{39}$ All figures in this paragraph are from Ana Swanson, "Big Pharmaceutical Companies Are Spending Far More on Marketing Than Research," Washington Post, February 11, 2015,

https://www.washingtonpost.com/news/wonk/wp/2015/02/11/big-pharmaceutical-companies-are-spending-farmore-on-marketing-than-research/?utm_term=.afdeddef6e77.

${ }^{40}$ See Royal Society, UK Research and the European Union: The Role of the EU in Funding UK Research (2015), https://royalsociety.org/ /media/policy/projects/eu-uk-funding/uk-membership-of-eu.pdf; and Technopolis, The Role of EU Funding in UK Research and Innovation (2017), https://www.raeng.org.uk/publications/reports/eu-funding-in-uk-research-and-innovation.

${ }^{41}$ Ekaterina Galkina Cleary, Jennifer M. Beierlein, Navleen Surjit Khanuja, Laura M. McNamee, and Fred D. Ledley, "Contribution of NIH Funding to New Drug Approvals 2010-2016," Proceedings of the National Academy of Sciences (PNAS) 115, no. 10 (2018): 2329-34, http://www.pnas.org/content/early/2018/02/06/1715368115. NIH funding during the period totaled more than $\$ 100$ billion.

${ }^{42}$ The critical role the large companies play is in development: they finance the clinical trials required for drug approval.

${ }^{43}$ Pfizer, "Pfizer Code of Ethics \& Conduct/ Pfizer Business Conduct Policies," https://www.pfizer.com/purpose/transparency/code-of-conduct.

${ }^{44}$ Johnson \& Johnson, "Our Credo," https://www.jnj.com/credo/.

${ }^{45}$ Oxfam Great Britain, Fiscal Justice Global Track Record (2016), https://policy-

practice.oxfam.org.uk/publications/fiscal-justice-global-track-record-oxfams-tax-budget-and-social-accountability620087.

${ }^{46}$ This is especially the case in developing countries, where corporate tax revenues make up twice as large a proportion of total tax revenues as in rich countries. UN Conference on Trade and Development (UNCTAD), World Investment Report 2015: Reforming International Investment Governance (2015), http://unctad.org/en/PublicationsLibrary/wir2015_en.pdf, cited in Esmé Berkhout, Tax Battles: The Dangerous Global Race to the Bottom on Corporate Tax (Oxfam, 2016),

https://www.oxfam.org/sites/www.oxfam.org/files/bp-race-to-bottom-corporate-tax-121216-en.pdf.

${ }^{47}$ Drew DeSilver, "Chart of the Week: How South Africa Changed, and Didn't, Over Mandela's Lifetime," Pew Research Center, December 13, 2016, http://www.pewresearch.org/fact-tank/2013/12/06/chart-of-the-week-howsouth-africa-changed-and-didnt-over-mandelas-lifetime/.

${ }^{48}$ World Bank, "The World Bank in South Africa," Overview, https://www.worldbank.org/en/country/southafrica/overview.

49 Department of Health/Republic of South Africa, "National Health Insurance for South Africa: Towards Universal Health Coverage," 2015, https://www.health-e.org.za/wp-content/uploads/2015/12/National-Health-Insurance-forSouth-Africa-White-Paper.pdf; Catherine Tomlinson, Heather Moyo, Zain Rizvi, Claire Waterhouse, Salomé Meyer, and Marcus Low, Exploring Patent Barriers to Cancer Treatment Access in South Africa: 24 Medicine Case Studies (Cancer Alliance/Fix the Patent Laws, 2017), https://www.canceralliance.co.za/wpcontent/uploads/2018/02/Exploring-Patent-Barriers-to-Cancer-Treatment-Access-in-SA-24-Medicine-CaseStudies-October-2017-update-January-2018.pdf. 
${ }^{50}$ Maulshree Seth, "BRD Medical College: 69 Children Dead in 4 days; 19 in Last 24 Hours," Indian Express, October 13, 2017, https://indianexpress.com/article/india/gorakhpur-hospital-children-death-brd-medical-collegeyogi-adityanath-69-children-dead-in-four-days-4886027/.

51 The developing countries examined were Chile, Colombia, Ecuador, India, Pakistan, Peru, and Thailand; the wealthy countries were Australia, Denmark, France, Germany, Italy, New Zealand, Spain, and the UK. The presence of the four companies in sub-Saharan Africa is very limited. Either the companies' products are not sold to consumers in many African countries, or they are imported and distributed by unrelated companies. Alternatively, the companies may be violating permanent establishment rules to avoid tax.

52 In June 2017, the OECD reported that only one country-Trinidad and Tobago-had failed to comply with international transparency standards, its only criteria to identify tax havens. Meanwhile, the EU decided to draft a blacklist based on more-ambitious assessment criteria, which it released in November 2016. Those criteria, which include a 0 percent corporate tax rate indicator and an assessment of the fairness of tax systems, are more comprehensive than those used by the OECD with stronger criteria than those adopted by the OECD/G20, based on a combination of lack of transparency, unfair taxation and harmful tax practices, and the failure to implement measures agreed at the OECD to curb tax avoidance. However, Oxfam believes that the EU process still lacks adequate clarity and transparency. The EU is moving ahead unilaterally, imposing a set of reforms to third countries, which raises questions of legitimacy.

${ }^{53}$ Council of the European Union, "The EU List of Non-Cooperative Jurisdictions for Tax Purposes," revised, 8304/1/18 (May 8, 2018), http://data.consilium.europa.eu/doc/document/ST-8304-2018-REV-1/en/pdf.

${ }^{54}$ The Irish government passed measures in 2015 to phase out by 2020 the use of Double Irish with a Dutch sandwich structure (which uses a combination of Irish and Dutch subsidiaries to shift profits to tax havens). The Netherlands is planning to introduce source taxation on interests and royalties to tax havens. In addition, by 2020 measures will take effect against hybrid mismatches (legal entities or instruments that are treated differently under the rules of different countries), which allow a US multinational to transfer profits-primarily from intellectual property royalty fees-out of the Netherlands without being taxed. See Joe Kirwin, "EU Laws Targeting Multinational Hybrid Mismatch Blocked," Bloomberg BNA, January 27, 2017, https://www.bna.com/eulaws-targeting-n73014450362/.

${ }^{55}$ Oxfam was unable to obtain tax data in the most secretive tax havens (e.g., Bermuda, Cayman Islands, and Switzerland) and instead examined data from those countries that are tax havens but have some actual manufacturing or research facilities. These countries seem to be used by the companies as "pivots," where profits are allocated before being allocated yet again to the more secretive jurisdictions.

${ }^{56}$ Institute for Tax and Economic Policy, Offshore Shell Games 2017: The Use of Offshore Tax Havens by Fortune 500 Companies (2017), https://itep.org/wp-content/uploads/offshoreshellgames2017.pdf.

${ }^{57}$ Data is from each company's $10-\mathrm{K}$ filings with the SEC. For Merck, the numbers for the Middle East and Africa are not reported separately from those of Europe.

${ }^{58}$ These figures are estimates that represent the difference between the taxes the companies say they pay and what they would pay under a system of global apportionment that assumes profit margins are equal across countries.

${ }^{59}$ CDC, "Genital HPV Infection-Fact Sheet"

${ }^{60}$ WHO, "Human Papillomavirus and Cervical Cancer," February 18, 2018, http://www.who.int/news-room/factsheets/detail/human-papillomavirus-(hpv)-and-cervical-cancer.

${ }^{61}$ Ibid.

62 UICC, "UICC Members Respond to the Global Call to Action."

${ }^{63}$ HPV Information Centre, http://www.hpvcentre.net/datastatistics.php. For statistics, select Module: "M2. Disease burden estimates"; Topic: "Cervical cancer"; Indicator: "Number of deaths."

${ }^{64}$ CDC, "HPC Vaccines: Vaccinating Your Preteen or Teen," https://www.cdc.gov/hpv/parents/vaccine.html.

${ }^{65}$ The CDC recommends two doses of the vaccine (CDC, "HPC Vaccine Information for Young Women," https://www.cdc.gov/std/hpv/stdfact-hpv-vaccine-young-women.htm) and Oxfam calculated these estimates by taking the estimated price paid for these vaccines in each country and multiplying by two doses. We then divided the estimated tax loss per each country by the price for two doses. Thailand price sources:

https://www.thaitravelclinic.com/cost.html; Latin American countries' price sources: prices from PAHO,

https://www.paho.org/hq/index.php?option=com_docman\&task=doc_download\&gid=43314\&ltemid=270\&lang=e; and prices are based on GAVI price of $\$ 4.50$ per dose:

https://www.unicef.org/supply/files/2018_03_08_HPV_.pdf. 
${ }^{66} \$ 73,780,584 / \$ 9=8,197,843$. We calculated the number of children born per year using the World Bank's crude birth rate and population figures for 2016: World Bank, "Birth Rate, Crude (Per 1,000 People),"

https://data.worldbank.org/indicator/SP.DYN.CBRT.IN?view=chart; and World Bank, "Population, Total," (data for 1960 and 2017), https://data.worldbank.org/indicator/SP.POP.TOTL. We divided in half for the number of girls born per year. Thus, our formula was: population $/ 1,000 \mathrm{x}$ birth rate $=$ children born per year $/ 2=$ girls born per year. Our results gave us 12,588,235 girls born each year in India and 355,783 in Thailand.

${ }^{67}$ HPV Information Centre, http://www.hpvcentre.net/datastatistics.php. For statistics, select Module: "M2. Disease burden estimates"; Topic: "Cervical cancer"; Indicator: "Number of deaths."

${ }^{68}$ Medecins Sans Frontières, https://www.afairshot.org/; Igor Rudan, Cynthia Boschi-Pinto, Zrinka Biloglav, Kim Mulholland, and Harry Campbell, "Epidemiology and Etiology of Childhood Pneumonia," Bulletin of the World Health Organization 86, no. 5 (2008): 408-16. doi:10.2471/BLT.07.048769.

69 Ibid.

${ }^{70}$ Kate O'Brien (International Vaccine Access Center), "Current Status of PCV Use and WHO Recommendations" (presentation, October 18, 2017), http://www.who.int/immunization/sage/meetings/2017/october/01_17_October_2017_Presentation_01_OBrien_S AGE_PCV.pdf.

${ }^{71}$ The recommended dosage is three shots, per Medecins Sans Frontières, https://www.afairshot.org/. Oxfam calculated these estimates by taking the estimated price paid for these vaccines in each country and multiplying by three doses. We then divided the estimated tax loss per each country by the price for three doses. Thailand price sources: https://www.thaitravelclinic.com/cost.html; Latin American countries' price sources: prices from PAHO,

https://www.paho.org/hq/index.php?option=com_docman\&task=doc_download\&gid=43314\&ltemid=270\&lang=en ; and Pakistan/India price sources, GAVI prices,

https://www.unicef.org/supply/files/18_01_08_PCV_Price_web_updates.pdf.

${ }^{72}$ Aaron Reeves, et al., "Financing universal health coverage-effects of alternative tax structures on public health systems: cross-national modelling in 89 low-income and middle-income countries," The Lancet 386, no. 9990 (July 18, 2015): 274-280, https://www.thelancet.com/journals/lancet/article/PIIS0140-6736(15)605748/fulltext.

${ }^{73}$ Georgios A. Kotsakis, "The burden of disease in Greece, health loss, risk factors, and health financing, 200016: an analysis of the Global Burden of Disease Study 2016," Lancet Public Health 2018; 3: e395-406; July 25, 2018, https://www.thelancet.com/pdfs/journals/lanpub/PIIS2468-2667(18)30130-0.pdf.

${ }^{74}$ Manoj Singh, "How Gorakhpur's BRD Medical College Struggled with Money and Manpower for Years," The Wire, August 13, 2017, https://thewire.in/health/gorakhpur-children-death-brd-medical-college-up-government. ${ }^{75}$ Ibid.

${ }^{76}$ Women are less likely than men to receive employer-provided health insurance simply because, worldwide, half of women are formally employed, compared with three-quarters of men. UN Women, Progress of the World's Women (2015). In Nigeria, female-headed households are twice as likely to be unable to seek treatment for an ill family member compared with male-headed households. See Kaiser Family Foundation, Gender Differences in Health Care, Status, and Use: Spotlight on Men's Health, slide 3, https://www.kff.org/womens-health-policy/factsheet/gender-differences-in-health-care-status-and-use-spotlight-on-mens-health/; and Michael N. Onah and Veloshnee Govender, "Out-of-Pocket Payments, Health Care Access and Utilisation in South-Eastern Nigeria: A Gender Perspective," PLoS ONE 9, no. 4 (2014). See also UNWomen, The Beijing Declaration and Platform for Action Turns 20 (2015),

http://www2.unwomen.org/ /media/headquarters/attachments/sections/library/publications/2015/sg\%20report_sy nthesis-en_web.pdf?v=1\&d=20150226T215547.

${ }^{77}$ Ana Langer, et al., "Women and Health: The Key for Sustainable Development," The Lancet 386, no. 9999 (September 19, 2015): 1165-1210, https://www.thelancet.com/action/showPdf?pii=S0140-

6736\%2815\%2960497-4; and "Women Are the Backbone of Healthcare with Few Rewards for \$3tn Contribution," Guardian, June 5, 2015, https://www.theguardian.com/global-development/2015/jun/05/women-backbonehealthcare-3tn-contribution.

${ }^{78}$ Calculations made as explained in note 3. See the annex, "Tax Research Methodology," for more information.

${ }^{79}$ Calculations for the United States are based on sales to unrelated US-based customers, not company affiliates. See the annex, "Tax Research Methodology," for details.

${ }^{80}$ It costs $\$ 2,371$ to pay for one year of healthcare for a low-income child in the US. See National Priorities Project, "Trade-Offs: Your Money, Your Choices," https://www.nationalpriorities.org/interactive-data/trade-offs/. 
${ }^{81}$ Merck's US earnings in recent years have tended to be slightly higher or equal to its overseas earnings, due primarily to extraordinary profits from the sale of subsidiaries.

${ }^{82}$ Americans for Tax Fairness, The Pharma Big 10: Price Gougers, Tax Dodgers (2017), 22.

${ }^{83}$ Institute for Taxation and Economic Policy, quoted in Rochelle Toplensky, "Multinationals Pay Lower Taxes Than a Decade Ago," Financial Times, March 12, 2018.

${ }^{84}$ Americans for Tax Fairness, The Parma Big 10.

${ }^{85} \mathrm{Ibid}$.

${ }^{86}$ Congressional Research Service (CRS), "Tax Cuts on Repatriation Earnings as Economic Stimulus: An Economic Analysis," December 20, 2011, https://fas.org/sgp/crs/misc/R40178.pdf, cited in Americans for Tax Fairness, The Pharma Big 10.

87 Ibid.

${ }^{88}$ Ibid., 8. See also William Lazonick, "Profits Without Prosperity," Harvard Business Review, September 2014, https://hbr.org/2014/09/profits-without-prosperity.

${ }^{89}$ See Michael Erman and Tom Bergin, "How US Tax Reform Rewards Companies That Shift Profit to Tax Havens," Reuters, June 18, 2018, https://www.reuters.com/article/us-usa-tax-abbvie/how-u-s-tax-reform-rewardscompanies-that-shift-profit-to-tax-havens-idUSKBN1JE12Q.

${ }^{90}$ The repatriation tax rate of 15.5 percent only applied to post-1986 earnings and profits considered to be cash and cash equivalents. All other repatriations were taxed at 8 percent.

91 Toplensky, "Multinationals Pay Lower Taxes Than a Decade Ago."

92 Sources: Americans for Tax Fairness, "Trump Tax Cut Truths: How Businesses in Your State Are Spending Their Tax Cuts," https://americansfortaxfairness.org/trumptaxcuttruths/. Merck 2018 tax cut estimated by JUST Capital, "The Just Capital Rankings on Corporate Tax Reform," https://justcapital.com/reports/the-just-capitalrankings-on-corporate-tax-reform/; and the Pfizer 2018 tax cut was estimated by the US Senate Committee on Finance, "Trump Tax Law and the Health Care Industry: A \$100 Billion Bonanza," April 17, 2018, https://www.finance.senate.gov/imo/media/doc/Wyden\%20Report\%20\%20Trump\%20Tax\%20Law\%20and\%20the\%20Health\%20Care\%20Industry\%20041718.pdf. The CEO-toworker pay ratio was compiled by Bloomberg based on company reports to the SEC; see Alicia Ritcey and Jenn Zhao, "Alphabet CEO Page Makes Tiny Fraction Copmared to Its Median Employee," https://www.bloomberg.com/graphics/ceo-pay-ratio/.

${ }^{93}$ Reuven Avi-Yonah, "The Tax Act Actually Promotes Off Shore Tax Tricks," American Prospect, June 28, 2018, http://prospect.org/article/tax-act-actually-promotes-shore-tax-tricks.

${ }^{94}$ Eric Zolt, "Tax Incentives: Protecting the Tax Base" (paper, Tax Incentives and Base Protection workshop, New York, April 23-24, 2015), http://www.un.org/esa/ffd/wp-content/uploads/2015/04/2015TIBP_PaperZolt.pdf.

${ }^{95}$ Tax Justice Network-Africa (TJNA) and ActionAid, Still Racing Toward the Bottom? Corporate Tax Incentives in East Africa (2016); World Bank, "Lifetime Risk of Maternal Death," 2015, http://data.worldbank.org/indicator/SH.MMR.RISK.

${ }^{96}$ Analysis of Nigerian budget by BudgIT, 2015 Budget: A Review of Proposed 2015 Budget 2, no. 1 (2015), http://yourbudgit.com/wp-content/uploads/2016/01/2015-Publication-BUGET.pdf.

${ }^{97}$ Government of the Netherlands, "6. Fiscale regelingen [tax arrangement]," Rijksbegroting [state budget], http://www.rijksbegroting.nl/2018/kamerstukken,2017/9/20/kst237146_6.html.

${ }^{98}$ Ibid.

${ }^{99}$ Grace Blakely, Fair Dues: Rebalancing Business Taxation in the UK (IPPR Commission on Economic Justice, 2018), https://www.ippr.org/files/2018-03/cej-income-tax-march18.pdf.

100 "Trump Says Drug Industry ‘Getting Away with Murder,” Politico, March 11, 2017,

http://www.politico.com/story/2017/01/trump-press-conference-drug-industry-233475. A study by the Homeland Security and Governmental Affairs Committee found that the prices of many prescription medicines increased 10 times more than inflation between 2012 and 2017. See US Senate Committee on Homeland Security and Governmental Affairs, "Breaking: Brand-Name Drugs Increasing at 10X Cost of Inflation McCaskill Report Finds," March 26, 2018, https://www.hsgac.senate.gov/media/minority-media/breaking-brand-name-drugs-increasing-at10x-cost-of-inflation-mccaskill-report-finds.

101 Open Secrets, "PhRMA Shows Biggest Spike in Lobbying Spending in First Quarter of President Trump," April 21, 2017, https://www.opensecrets.org/news/2017/04/phrma-shows-biggest-spike-in-lobbying-spending-in-firstquarter-of-president-trump/. 
102 "President Trump Meeting with Pharmaceutical Company Executives," C-SPAN, January 31, 2017, https://www.c-span.org/video/?423259-1/president-trump-tells-phrma-executives-streamline-fda.

103 Oxfam calculations are derived from data presented by Center for Responsive Politics, "Industry Profile Summary: 2017," https://www.opensecrets.org/lobby/indusclient.php?id=h04.

104 The deliberations of the working group surfaced in June 2017. "Documents Shed Light on Trump's Drug Pricing and Innovation Working Group," MedCity News, June 19, 2017, https://medcitynews.com/2017/06/trumps-drug-pricing-and-innovation-working-group-discussions/.

105 "With Trump Appointees, a Raft of Potential Conflicts and 'No Transparency,"” New York Times, April 15, 2017, https://www.nytimes.com/2017/04/15/us/politics/trump-appointees-potential-conflicts.html. Gottlieb received over $\$ 350,000$ from nearly a dozen pharmaceutical companies in 2014 and 2015. For details, see "Exclusive: White House Task Force Echoes Pharma Proposals," KHN, June 16, 2017, http://khn.org/news/exclusive-whitehouse-task-force-echoes-pharma-proposals/; and US House of Representatives, Committee on Energy and Commerce, Testimony of Robert J. Shapiro, http://docs.house.gov/meetings/IF/IF16/20151027/104110/HHRG114-IF16-Bio-ShapiroR-20151027-U1.pdf.

${ }^{106}$ US Office of Government Ethics, Nominee Report for Scott Gottlieb, https://assets.documentcloud.org/documents/3535249/Gottlieb-Scott.pdf.

107 "Price Out as HHS Secretary After Private Plane Scandal," CNN, September 29, 2017, https://www.cnn.com/2017/09/29/politics/tom-price-resigns/index.html.

108 Tomas Philipson webpage, Harris Public Policy, University of Chicago, https://harris.uchicago.edu/directory/tomas-philipson. See also Sarah Karlin-Smith, "Trump Tweets Up a Storm on Drug Prices but Delivers Little Change," Politico, August 15, 2017,

https://www.politico.com/story/2017/08/15/trump-drug-prices-medicare-241673?lo=ap_d1.

${ }^{109}$ Clark Strategy Group. See Offices of Senators Elizabeth Warren and Sheldon Whitehouse, President Trump's Drain the Swamp Report Card (July 2017), https://www.warren.senate.gov/files/documents/2017_07_20_Trump_Drain_the_Swamp_Report_Card.pdf.

${ }^{110}$ Skadden, Arps, Slate, Meagher \& Flom LLP. Members of Lighthizer's team at the US Trade Representative's office who also worked at Skadden include Chief of Staff Jamieson Greer, Deputy Chief of Staff Pamela Marcus, and General Counsel Stephen Vaughn, plus Deputy Trade Representative for Asia, Europe, the Middle East, and Industrial Competitiveness Jeff Gerish.

${ }^{111}$ For details, see Scott Higham and Lenny Bernstein, "The Drug Industry's Triumph over the DEA," Washington Post, October 15, 2017.

${ }^{112}$ Center for Responsive Politics, "Lobbyists: Pharm/Health Prod, 2017," opensecrets.org, https://www.opensecrets.org/lobby/indusclient_lobs.php?id=H04\&year=2017.

${ }^{113}$ Ibid. The proportion of revolvers working for the pharmaceutical industry has held steady at about 60 percent since 2010. The percentage for PhRMA lobbyists is 72 percent. See Center for Responsive Politics, "Lobbyists Representing Pharmaceutical Research \& Manufacturers of America, 2017," https://www.opensecrets.org/lobby/clientlbs.php?id=D000000504\&year=2017.

${ }^{114}$ All figures in this paragraph are Oxfam calculations from data in Center for Responsive Politics, "Industry Profile: Summary, 2017."

${ }^{115}$ In all, the four companies spent an estimated \$2.8 million lobbying on tax issues during the first six months of 2017. See Center for Responsive Politics, "Industry Profile: Summary, 2017". For the full year 2017, the four companies filed 468 lobbying reports, of which 95 (20 percent) were on taxation. All but Merck filed more reports on taxation than any other issue.

${ }^{116}$ Chris McGreal, "How Big Pharma's Money_and Its Politicians-Feed the US Opioid Crisis," Guardian, October 19, 2017, https://www.theguardian.com/us-news/2017/oct/19/big-pharma-money-lobbying-us-opioidcrisis.

117 Oxfam analysis of data from Center for Responsive Politics, lobbyists' Linkedln profiles, and lobbying firm profiles. These committees are also responsible for trade, and therefore for intellectual property provisions in trade agreements, and for health care reform.

${ }^{118}$ Federal Lobbying Disclosures, https://lobbyingdisclosure.house.gov/index.html.; also "Raissa H. Downs," Tarplin Downs Young, http://www.tdyllc.com/raissa-h-downs-2/; "Karina V. Lynch," Williams \& Jensen, http://www.williamsandjensen.com/about-us/principals-associates/karina-v-lynch; "Tucker Shumack," Ogilvy Government Relations, https://www.ogilvygr.com/team/tucker-shumack/; and "Charlotte Ivancic," Tarplin Downs Young, http://www.tdyllc.com/charlotte-ivancic/. 
119 Ibid.

${ }^{120}$ Federal Lobbying Disclosures, https://lobbyingdisclosure.house.gov/index.html. Pfizer deployed 39 lobbyists on tax issues during those six months and spent by far the most on lobbying: $\$ 5.6$ million, of which an estimated \$1.5 million was on tax issues. Merck spent \$3.7 million using 25 lobbyists, while Johnson \& Johnson spent \$2.4 million and had 11 lobbyists, and Abbott spent $\$ 1.65$ million and deployed 18 lobbyists on tax issues.

${ }^{121}$ Center for Responsive Politics, lobbyists' LinkedIn profiles, and lobbying firm profiles.

${ }^{122}$ See, for example, Pfizer, "Talking Points: Ian Read at the Medical Innovation Summit," August 29, 2017, https://www.pfizer.com/news/featured_stories/featured_stories_detail/talking_points_ian_read_at_the_medical_in novation_summit.

${ }^{123}$ Oxfam calculations based on Data from Federal Elections Commission filings compiled by the Center for Responsive Politics (https://www.opensecrets.org). A political action committee pools campaign contributions from members and donates those funds to campaign for or against candidates, ballot initiatives, or legislation.

${ }^{124}$ The opensecrets.org website and Public Citizen, the Center for Public Integrity, local newspapers, and company websites have information on many of these individuals. On Sessions, see https://www.opensecrets.org/members-of-congress/contributors?cid=N00003062\&cycle=2010\&recs=100\&type=I; on Coats, see https://www.citizen.org/sites/default/files/pharmadrugwar.pdf,

https://www.opensecrets.org/members-of-congress/summary?cid=N00003845, and

https://www.pfizer.com/files/investors/corporate/2009_2010_pac_report.pdf; on Pompeo, see

https://www.opensecrets.org/members-of-congress/industries?cid=N00030744\&cycle=CAREER\&type=I; on

Perry, see https://www.publicintegrity.org/2011/11/16/7414/heart-testing-bill-signed-perry-required-unnecessarytests-critics-charge; on Pence, see https://www.opensecrets.org/members-ofcongress/contributors?cid=N00003765\&cycle $=2012 \&$ recs $=100 \&$ type $=C$,

https://www.indystar.com/story/news/politics/2018/01/31/whos-giving-big-money-vice-president-mike-pencesleadership-pac-lots-corporations/1084951001/, https://www.naturalblaze.com/2017/03/obamacare-2-0-mikepence-paul-ryan-pharma-corruption-trump-admin.html, and http://www.ibtimes.com/political-capital/who-lobbyingmike-pence-why-health-insurers-big-oil-seek-influence-vice-president. Pence has met with PhRMA concerning nearly 40 pieces of legislation since taking office.

${ }^{125}$ Oxfam calculations based on Data from Federal Elections Commission filings compiled by Center for Responsive Politics (https://www.opensecrets.org).

${ }^{126}$ Oxfam calculations based on Data from Federal Elections Commission filings compiled by Center for Responsive Politics (https://www.opensecrets.org).

127 Jay Hancock, "The Stealth Campaign to Kill Off Obamacare," New York Times, July 27, 2018.

${ }^{128}$ Ibid

${ }^{129}$ A compulsory license authorizes generic production of a patented drug, with fair compensation to the patentholder, in accordance with the WTO Agreement on Trade-Related Intellectual Property (TRIPS agreement).

${ }^{130}$ David Brunnstrom, "US Lawmakers Urge Trump to Press India's Modi on Trade, Investment," Reuters, June 24, 2017, http://www.reuters.com/article/us-usa-india-trade-idUSKBN19F0QQ.

131 "Las presiones internacionales contra Colombia," Contamos.

132 Such demands often seek to heighten patent protection beyond the WTO's TRIPS agreement. They can include patents for new uses or methods of using a known product, prohibition on pre-grant patent opposition, test data exclusivity periods, patent term extensions for "unreasonable" regulatory or marketing delays, patent linkage, limits on compulsory licensing grounds, limits on parallel imports, and more stringent enforcement of intellectual property rights. For a useful summary, see "Promoting Innovation and Access to Health Technologies," Report of the United Nations Secretary-General's High-Level Panel on Access to Medicines," 25.

${ }^{133}$ Kent Bressie, Patricia Paoletta, and William Leahy, "HWG Regulatory Advisory: USTR Initiates Annual 'Special 301' Review of Countries Lacking Adequate Intellectual Property Rights Protection," Harris, Wiltshire \& Grannis, January 12, 2017, https://www.hwglaw.com/hwg-regulatory-advisory-ustr-initiates-annual-special-301review-countries-lacking-adequate-intellectual-property-rights-protection/. See also Sean M. Flynn, "Special 301 of the Trade Act of 1974 and Global Access to Medicine," Digital Commons @ American University Washington College of Law, January 1, 2010, http://digitalcommons.wcl.american.edu/cgi/viewcontent.cgi?article=1000\&context=pijip_facsch.

134 "New Leaked Merck Missive Reveals Deep Drug, Medical Device Company Opposition to South African Patent Reforms," Knowledge Ecology International, January 20, 2014, https://www.keionline.org/22398. 
${ }^{135}$ Countries on the 2018 Priority Watch list are Algeria, Argentina, Canada, Chile, China, Colombia, India, Indonesia, Kuwait, Russia, Ukraine, and Venezuela. Office of the US Trade Representative, "2018 Special 301 Report on Intellectual Property Rights," April 2018,

https://ustr.gov/sites/default/files/files/Press/Reports/2018\%20Special\%20301.pdf. Of the 19 overseas markets where PhRMA indicated "urgent action is required to address serious market access and intellectual property barriers", the US Trade Representative included all but 5 (Australia, EU, Japan, Korea and Malaysia) in its 2018 Special 301 report. See https://www.phrma.org/policy-paper/phrma-special-301-submission-2018.

${ }^{136}$ Countries on the 2018 Watch List are Barbados, Bolivia, Brazil, Costa Rica, Dominican Republic, Ecuador, Egypt, Greece, Guatemala, Jamaica, Lebanon, Mexico, Pakistan, Peru, Romania, Saudi Arabia, Switzerland, Tajikistan, Thailand, Turkey, Turkmenistan, the United Arab Emirates, Uzbekistan, and Vietnam. Office of the US Trade Representative, "2018 Special 301 Report on Intellectual Property Rights," April 2018, https://ustr.gov/sites/default/files/files/Press/Reports/2018\%20Special\%20301.pdf.

137 Ibid.

${ }^{138}$ Centre for Innovation in Regulatory Science, "The Changing Regulatory Environment in Latin America: Focus on Good Review Practices” R\&D Briefing 58, December 2015, http://www.cirsci.org/wpcontent/uploads/2016/01/CIRS-RD-Briefing-58-FINAL-for-distribution.pdf.

${ }^{139}$ World Health Organization (WHO), Measuring Transparency in the Public Pharmaceutical Sector: Assessment Instrument (2009), http://infocollections.org/medregpack/documents/d0161/d0161.pdf. See also IMS Institute for Healthcare Informatics, "Understanding the Role and Use of Essential Medicines Lists," April 2015, https://www.imshealth.com/files/web/IMSH\%20Institute/Healthcare\%20Briefs/IIHI_Essential_Medicines_Report 2015.pdf.

${ }^{140}$ Waldron's March 13, 2013, testimony before the House Ways and Means Committee Subcommittee on Trade can be read here: http://waysandmeans.house.gov/UploadedFiles/Pfizer_testimony31313.pdf. India was a founding member of the WTO in 1995, but as a developing country it was given a five-year grace period before having to comply with the TRIPS agreement, and a 10-year grace period before having to protect technologies that were previously unprotected in its market.

141 Judit Rius Sanjuan, "Protect the 'Pharmacy of the Developing World," The Hill, June 7, 2016, http://thehill.com/blogs/congress-blog/foreign-policy/282375-doctors-without-borders-to-india-protect-thepharmacy-of.

${ }^{142}$ See Alliance for Fair Trade with India, "India's Unfair Actions Threaten Jobs and Economic Opportunity in America," homepage, http://aftindia.org/.

${ }^{143}$ Subcommittee on Commerce, Manufacturing, and Trade of the Committee on Energy and Commerce.

${ }^{144}$ See US Senate Committee on Finance, "Congressional Trade Leaders Fight India's Unfair Trade Practices," news release, August 2, 2013, http://www.finance.senate.gov/newsroom/chairman/release/?id=21cccccd-bed44bd8-89f9-7b9123ed8557.

${ }^{145}$ Governors' Letter to President Obama, September 24, 2013, http://aftindia.org/wpcontent/uploads/2013/09/Governors-Letter-to-President.pdf.

${ }^{146}$ For example, in May 2016 India reversed its decision to reject a patent application by the US pharmaceutical company Gilead for its Solvadi hepatitis $C$ medication, on grounds of treatment efficacy as well as on its cost ( $\$ 84,000$ per year per patient in the US). An Indian advocacy group claimed the decision was due to political pressure. See Ed Silverman, "Gilead Gets a Big Win as India Upholds a Sovaldi Patent, After All," STAT, May 10, 2016, accessed November 8, 2016, https://www.statnews.com/pharmalot/2016/05/10/gilead-hepatitis-patentsdrug-pricing/.

${ }^{147}$ Amit Sengupta, "India Assures the US It Will Not Issue Compulsory Licenses on Medicines," The Wire, March 12, 2016, https://thewire.in/24621/india-assures-the-us-it-will-not-issue-compulsory-licences-on-medicines/. The TRIPS agreement does not restrict the grounds on which developing countries can issue compulsory licenses.

148 See Letter from the Colombian Embassy to Colombia's foreign minister, April 27, 2016, https://www.keionline.org/wp-content/uploads/Florez-27April2016.pdf.

${ }^{149}$ See "Lighthizer Outlines List of Actions Colombia Must Take Ahead of OECD Accession," Inside US Trade's World Trade Online, February 26, 2018, https://insidetrade.com/daily-news/lighthizer-outlines-list-actionscolombia-must-take-ahead-oecd-accession. See also Ed Silverman, "PhRMA is angered by Colombia's move to cut prices for hepatitis C drugs,", StatNews, January 22 2018,

https://donttradeourlivesaway.wordpress.com/2018/01/22/phrma-is-angered-by-colombias-move-to-cut-pricesfor-hepatitis-c-drugs/; and Letter from PhRMA to the Colombian Health Minister, January 15, 2018,

https://www.keionline.org/wp-content/uploads/2018/01/PhRMA-Comments-on-Colombia-Resolution-5246.pdf ; Inside US Trade, "GOP lawmakers: Colombia has work to do before US should support OECD accession," April 
17, 2018, https://insidetrade.com/daily-news/gop-lawmakers-colombia-has-work-do-us-should-support-oecdaccession; and see PhRMA, "PhRMA Submission to US Trade Representative for the 2017 Special 301 Out-ofCycle Review of Colombia," https://www.regulations.gov/document?D=USTR-2017-0019-0005; Inside US Trade, "Industry, IP groups flag concerns in out-of-cycle Special 301 review of Colombia," October 27, 2017, https://insidetrade.com/daily-news/industry-ip-groups-flag-concerns-out-cycle-special-301-review-colombia.

${ }^{150}$ See "Special301," Knowledge Ecology International, https://www.keionline.org/ustr/special301.

${ }^{151}$ Nicolàs Sepúlveda, "Agresivo lobby de laboratorios contra resolución que baja millonario precio de medicamento," CIPER, July 24, 2018, https://ciperchile.cl/2018/07/24/agresivo-lobby-de-laboratorios-contraresolucion-que-baja-millonario-precio-de-medicamento/.

152 UNAIDS, "HIV and Aids Estimates," Country Factsheets: Thailand, 2017, http://www.unaids.org/en/regionscountries/countries/thailand/.

${ }^{153}$ At the time, Thailand had the highest incidence of the disease in Asia. See "Decree of Department of Disease Control, Ministry of Public Health, Regarding Exploitation of Patent on Drugs \& Medical Supplies by the Government on Combination Drug Between Lopinavir \& Ritonavir," January 29, 2007, http://www.cptech.org/ip/health/c/thailand/thai-cl-kaletra_en.pdf. In 2013, Abbott separated into two companies, Abbott and AbbVie; Abbvie holds the portfolio for most pharmaceuticals, including Kaletra. Also, see "Lopinavir/Ritonavir (LPV/r)," in Untangling the Web of Antiretroviral Price Reductions, 18th ed. (July 2016), https://www.msfaccess.org/sites/default/files/MSF_assets/HIV_AIDS/Docs/UTW_Drug_Profiles_LPV_r.pdf.

154 "Abbott Pulls New HIV Drug in Thailand," Financial Times, March 13, 2007, https://www.ft.com/content/5a5a88c2-d1a6-11db-b921-000b5df10621. See also, Public Citizen, "KaletraAbbott's Abusive Practices" https://www.citizen.org/our-work/access-medicines/kaletra-campaign/kaletra-abbottsabusive-practices.

155 "Thailand Takes on Drug Industry and May Be Winning," New York Times, April 11, 2007, https://www.nytimes.com/2007/04/11/world/asia/11iht-pharma.4.5240049.html; "PhRMA takes aim at Thailand for production of generics, hints that it will push for sanctions," The Hill, May 23, 2007, http://thehill.com/business-alobbying/3115-phrma-takes-aim-at-thailand-for-production-of-generics-hints-that-it-will-push-for-sanctions.

${ }^{156}$ Ibid. After protests by some of Abbott's shareholders, Abbott offered to sell Kaletra in Thailand for $\$ 1,000$ per patient per year, but again insisted Thailand abandon the compulsory license. See James Hookway and Nicholas Zamiska, "Harsh Medicine: Thai Showdown Spotlights Threat to Drug Patents," Wall Street Journal, April 24, 2007, available at http://www.cptech.org/ip/health/c/thailand/wsj04242007.html.

${ }^{157}$ Congress of the United States to the Honorable Susan C. Schwab, US Trade Representative, March 15, 2007, http://www.cptech.org/ip/health/c/thailand/house03152007.pdf.

${ }^{158}$ Data for Abbott's contributions: https://www.opensecrets.org/pacs/pacgot.php?cmte=C00040279\&cycle=2008; data for Merck: https://www.opensecrets.org/pacs/pacgot.php?cmte=C00097485\&cycle=2008.

${ }^{159}$ Public Citizen, "Kaletra-Abbott's Abusive Practices."

160 "Chronology of Access to Medicine Campaign in Thailand," Make Medicines Affordable: End Unfair Monopolies, December 3, 2015, http://makemedicinesaffordable.org/en/chronology-of-access-to-medicinecampaign-in-thailand/.

${ }^{161}$ See "Leaked Cables Show US Tried, Failed to Organize Against Ecuador Compulsory Licensing," Public Citizen, May 10, 2011, https://www.citizen.org/our-work/health-and-safety/leaked-cables-show-us-tried-failedorganize-against-ecuador. Ecuador was placed on the US Trade Representative Watch List, and then after actually issuing licenses in 2015 was moved to the Priority Watch List; within the year, Ecuador had backed down and suspended several licenses.

${ }^{162}$ According to leaked documents, the US Embassy in Brazil served as a channel to relay messages to drug companies including Merck and Abbott in 2010 stating that Brazil would issue compulsory licenses for HIV drugs unless the companies lowered their prices. See Elizabeth Dickinson, "Brazil's Pharma Pressure Campaign for Cheap HIVIAIDS Drugs," Foreign Policy, December 17, 2010, http://foreignpolicy.com/2010/12/17/brazilspharma-pressure-campaign-for-cheap-hivaids-drugs/.

163 "Promoting Innovation and Access to Health Technologies," 24.

164 Ibid. On IAPO, see https://www.iapo.org.uk/.

${ }^{165}$ The companies fund similar patients groups in wealthy countries. See Lupkin and Lucas, "Patient Advocacy Groups Take in Millions from Drugmakers."

${ }^{166}$ Mark Kramer, "What's Wrong with Maximising Shareholder Value?," Guardian, November 8, 2012, https://www.theguardian.com/sustainable-business/blog/maximising-shareholder-value-irony. 
${ }^{167}$ See Scott Higham and Lenny Bernstein, "The Drug Industry's Triumph over the DEA," Washington Post October 15, 2017.

${ }^{168}$ See the Pharmacy Benefits Consultants listing: http://www.pharmacybenefitconsultants.com/wpcontent/uploads/2018/03/AWP-Comparison-20161231-to-20180301.pdf.

${ }^{169}$ See Sarah Karlin-Smith and Andrew Restuccia, "Trump Meets with Drug Giant's CEO as Part of Price Squeeze," Politico, July 19, 2018, https://www.politico.com/story/2018/07/19/trump-pfizer-ceo-drug-prices700170?utm_source=STAT+Newsletters\&utm_campaign=f0820d1767-

Pharmalittle_COPY_01\&utm_medium=email\&utm_term=0_8cab1d7961-f0820d1767-149629337.

${ }^{170}$ Since the WTO's TRIPS agreement came into force in 1995, patents in virtually every country last for 20 years.

${ }^{171}$ Melissa Barber, Dzintars Gotham, and Andrew Hill, "Potential Price Reductions for Cancer Medicines on the WHO Essential Medicines List," poster, January 2017,

https://www.researchgate.net/publication/313064230_Potential_price_reductions_for_cancer_medicines_on_the_ WHO_Essential_Medicines_List. The WHO's List of Ëssential Medicines lists 39 medicines that are a high priority for cancer treatment worldwide, also available at https://www.ejcancer.com/article/S0959-8049(17)30471-9/pdf

${ }^{172}$ Calculated from data in Barber, Gotham, and Hill, "Potential Price Reductions."

173 See Aaron S. Kesselheim, Jerry Avorn, and Ameet Sarpatwari, "The High Cost of Prescription Drugs in the United States: Origins and Prospects for Reform," Journal of the American Medical Association 316 , no. 8 (August 23, 2016): 858-71, https://jamanetwork.com/journals/jama/article-abstract/2545691? redirect=true.

${ }^{174}$ Cleary, Beierlein, Khanuja, McNamee, and Ledley, "Contribution of NIH Funding to New Drug Approvals 2010-2016."

${ }^{175}$ See Royal Society, UK Research and the European Union: The Role of the EU in Funding UK Research; and Technopolis, The Role of EU Funding in UK Research and Innovation.

${ }^{176}$ GAO, "Drug Industry: Profits, Research and Development Spending."

${ }^{177}$ Ibid. The companies also receive federal tax breaks to encourage R\&D spending, including the orphan drug credit, which increased more than fivefold from 2005 through 2014.

${ }^{178}$ All figures in this paragraph are from Ana Swanson, "Big Pharmaceutical Companies Are Spending Far More on Marketing Than Research," Washington Post, February 11, 2015,

https://www.washingtonpost.com/news/wonk/wp/2015/02/11/big-pharmaceutical-companies-are-spending-farmore-on-marketing-than-research/?utm_term=.afdeddef6e77.

${ }^{179}$ Ibid. Since 2013 the overall total for sales and marketing of the top 10 companies has fluctuated between $\$ 22$ billion and $\$ 27$ billion.

${ }^{180}$ WHO, Women and Health: Today's Evidence Tomorrow's Agenda (2009), http://www.who.int/gender-equityrights/knowledge/9789241563857/en/; See also Steven N. Austad and Kathleen E. Fischer, "Sex Differences in Lifespan," Cell Metabolism 23, no. 6 (2016): 1022, 1026-28, https://dx.doi.org/10.1016/j.cmet.2016.05.019.

${ }^{181}$ Chean R. Men, Kate Frieson, Chi Socheat, Hou Nirmita, and Chev Mony, "Gender as a Social Determinant of Health: Gender Analysis of the Health Sector in Cambodia" (paper, World Conference on Social Determinants of Health, Rio de Janeiro, Brazil, October 19-20, 2011),

https://www.who.int/sdhconference/resources/draft_background_paper15_cambodia.pdf; Nandita Saikia, Jayanta Kumar Bora, and Moradhvaj Dhakad, "Gender Difference in Health-Care Expenditure: Evidence from India Human Development Survey," PLoS ONE 11, no. 7 (2016),

http://journals.plos.org/plosone/article?id=10.1371/journal.pone.0158332; Gary Owens, "Gender Differences in Health Care Expenditures, Resource Utilization, and Quality of Care," Journal of Managed Care Pharmacy 14, no. S3 (2016), http://www.amcp.org/data/jmcp/JMCPSupp_April08_S2-S6.pdf. On maternal responsibilities, see UNICEF/Every Woman Every Child, The Global Strategy for Women's, Children's and Adolescents' Health (2016-2030): Survive, Thrive, Transform (2015), 25, https://data.unicef.org/wpcontent/uploads/2017/02/EWEC_globalstrategyreport_200915_FINAL_WEB.pdf.

182 UNICEF/Every Woman Every Child, The Global Strategy for Women's, Children's and Adolescents' Health.

${ }^{183}$ WHO, Addressing the Challenge of Women's Health in Africa (2012), 17. In one US study, the average medical cost for women affected by physical domestic violence was $\$ 483$ compared with $\$ 83$ for men. See Center for Disease Control, "CDC Study Documents High Costs and Impact of Intimate Partner Violence," (Oct. 25, 2005), https://www.cdc.gov/media/pressrel/r051025.htm.

${ }^{184}$ This situation occurs in part because foods rich in iron, like red meat, are often given to men and boys, even though women and girls need iron more to compensate for blood lost during childbirth and menstruation. See 
Marleen Temmerman, Rajat Khosla, Laura Laski, Zoe Mathews, and Lale Say, "Women's Health Priorities and Interventions," BMJ 351, no. S1 (2015), https://www.bmj.com/content/351/bmj.h4147; and Rachel Snow, Sex, Gender and Vulnerability, Population Studies Center Research Report 07-628 (2007), https://www.psc.isr.umich.edu/pubs/pdf/rr07-628.pdf.

${ }^{185}$ WHO, Addressing the Challenge of Women's Health in Africa.

${ }^{186}$ WHO, Addressing the Challenge of Women's Health in Africa, 41; and Eleanor MacPherson, Esther Richards, Ireen Namakhoma, and Sally Theobald, "Dimensions of Gender Equity in Health in East and Southern Africa," Equinet Discussion Paper 90 (2012), 17.

${ }^{187}$ Miriam N. Nkangu, Oluwasay A. Olatunde, and Sanni Yaya, "The Perspective of Gender on the Ebola Virus Using a Risk Management and Population Health Framework: A Scoping Review," Infectious Diseases of Poverty 6 (2017); UN Development Program (UNDP), Human Development Report 2015: Work for Human Development (2015), 121, http://report.hdr.undp.org/.

${ }^{188}$ Data from 2003. See Owens, "Gender Differences in Health Care Expenditures, Resource Utilization, and Quality of Care." See also Lisa R. Shugarman, Chole E. Bird, Cynthia R. Schuster, and Joanne Lynn, "Age and Gender Differences in Medicare Expenditures and Service Utilization at the End of Life for Lung Cancer Decedents," Women's Health Issues 18, no. 3 (2008), https://www.whijournal.com/article/S1049-3867(08)000352/fulltext, which found that Medicare expenditures for women with lung cancer were $\$ 1,900$ greater than those of men. And also see Rose Rimler, "Should Women Pay More for Heathcare Services?," Healthline, June 13, 2016, https://www.healthline.com/health-news/should-women-pay-more-healthcare-services.

${ }^{189}$ WHO, Addressing the Challenge of Women's Health in Africa; MacPherson, Richards, Namakhoma, and Theobald, "Dimensions of Gender Equity in Health in East and Southern Africa"; Belen Pedrique, Nathalie StrubWourgaft, Claudette Some, Piero Olliaro, Patrice Trouiller, Nathan Ford, Bernard Pécoul, and Jean-Hervé Bradol, "The Drug and Vaccine Landscape for Neglected Diseases (2000-11): A Systematic Assessment," Lancet Global Health 1, no. 6 (2013). See also "Cheap Blood Drug Could Prevent Maternal Death Globally," Daily Star, April 30, 2017, http://www.thedailystar.net/health/cheap-blood-drug-could-prevent-maternal-death-globally-1398415; and Simon Brooker, Peter J. Hotez, and Donald A.P. Bundy, "Hookworm-Related Anemia Among Pregnant Women: A Systemic Review," PLOS Neglected Tropical Diseases 2, no. 9 (2008), journals.plos.org/plosntds/article?id=10.1371/journal.pntd.0000291; and Vanessa Christinet, Janis K. Lazdins-Helds, J. Russell Stothard, and Jutta Reinhard-Rupp, "Female Genital Schistosomiasis (FGS): From Case Reports to a Call for Concerted Action Against This Neglected Gynaecological Disease," International Journal for Parasitology 46, no. 7 (2016).

${ }^{190}$ Amy Westervelt, "The Medical Research Gender Gap: How Excluding Women from Clinical Trials Is Hurting Our Health," Guardian, April 30, 2015, https://www.theguardian.com/lifeandstyle/2015/apr/30/fda-clinical-trialsgender-gap-epa-nih-institute-of-medicine-cardiovascular-disease; Randy Dotinga, "Pregnant Women in Clinical Trials: FDA Questions How to Include Them," Ob.Gyn. News (April 9, 2018); and Chiara Melloni et al., "Representation of Women in Randomized Clinical Trials of Cardiovascular Disease Prevention," Circulation. Cardiovascular Quality and Outcomes 3, no. 2 (March 2010): 135-42.

191 Lazonick et al., "US Pharma's Financialized Business Model."

192 Ibid. Lazonick records buybacks and dividends as a percentage of net income (profit after capital spending) and research and development as a percentage of sales (revenue). For ease of comparison, in the table and surrounding paragraphs we have calculated both as a percentage of revenue.

${ }^{193}$ William Lazonick, Matt Hopkins, and Öner Tulum, "Tax Dodging Just One Part of Pfizer's Corrupt Business Model," Huffington Post, December 4, 2015, http://www.huffingtonpost.com/william-lazonick/tax-dodging-just-onepart_b_8721900.html.

${ }^{194}$ Lazonick et al., "US Pharma's Financialized Business Model."

${ }^{195}$ Bob Herman, "Pharma's \$50 Billion Tax Windfall for Investors," Axios, February 22, 2018, https://www.axios.com/pharma-share-buyback-tax-reform-40a30b93-6149-4c67-bd65-cd05ee814215.html.

${ }^{196}$ Office of Senator Cory A. Booker, "New Booker Report Highlights How Pharma Firms Are Using Tax Savings: Windfall Not Being Used to Reduce Drug Prices," press release, April 10, 2018,

https://www.booker.senate.gov/?p=press_release\&id=767; and the report from Booker's office, With New Tax Savings, Drug Companies Start by Rewarding Shareholders, Not Patients Struggling with Skyrocketing Prices: An Investigative Analysis by the Office of Senator Cory A. Booker (April 9, 2018, with addendum attached June 22, 2018), https://www.scribd.com/document/382351279/Pharma-Tax-Report-6-21-With-Addendum.

${ }^{197}$ David Phillips, "Pfizer's Pipeline Story Begins to Unravel," YCharts, August 30, 2013, http://finance.yahoo.com/news/pfizer-pipeline-story-begins-unravel-143509405.html; Maggie McGrath, "Drug Patent Expirations Continue to Hit Pfizer Revenue," Forbes, January 28, 2014; and Maggie McGrath, "Merck 
Sales Slide on Expiring Drug Patents but Shares Lifted by Cancer-Fighting Collaboration," Forbes, February 5, 2014. All quoted in Lazonick et al., "US Pharma's Financialized Business Model."

198 Ibid.

${ }^{199}$ Data from S\&P Global Market Intelligence and Equilar. See Krantz, "Drug Prices Are High.”

${ }^{200}$ Arstecnica pegs Reid's compensation at \$27.9 million; Equilar 200 put it at $\$ 26.2$ million. See arstecnica, "Pfizer CEO Gets 61\% Pay Raise-to \$27.9 Million-as Drug Prices Continue to Climb," March 16, 2018, https://arstechnica.com/science/2018/03/amid-drug-price-increases-pfizer-ceo-gets-61-pay-raise-to-27-9-million/; Equilar 200 reported in Equilar and New York Times, "The 10 Highest-Paid CEOs in 2017."

201 arstecnica, "Pfizer CEO."

202 Equilar and New York Times, "The 10 Highest-Paid CEOs in 2017," based on the annual Equilar 200 studies.

${ }^{203}$ Annual Equilar 200 studies, as reported in Equilar and New York Times, "The 10 Highest-Paid CEOs in 2017."

${ }^{204}$ All information in this box is drawn from Public Citizen, "Twenty-Seven Years of Pharmaceutical Industry

Criminal and Civil Penalties: 1991 Through 2017," https://www.citizen.org/our-work/health-andsafety/pharmaceutical-industry-penalties.

${ }^{205}$ See "Johnson \& Johnson Settles Bribery Complaint for \$70 Million in Fines," New York Times, April 8, 2011, https://www.nytimes.com/2011/04/09/business/09drug.html.

206 "Pfizer Settles US Charges of Bribing Doctors Abroad," New York Times, August 7, 2012,

https://www.nytimes.com/2012/08/08/business/pfizer-settles-us-charges-of-overseas-bribery.html; and the SEC complaint to US District Court, District of Columbia: US Securities and Exchange Commission vs. Pfizer Inc., https://www.sec.gov/litigation/complaints/2012/comp-pr2012-152-pfizer.pdf.

207 Jonathan Stempel, "Pfizer to Pay \$23.85 Million to Settle US Co-Payment Kickback Probe," Reuters, May 24, 2018, https://www.reuters.com/article/us-pfizer-settlement/pfizer-to-pay-2385-million-to-settle-us-co-paymentkickback-probe-idUSKCN1IP2CZ.

${ }^{208}$ Gardiner Harris, "Pfizer Pays \$2.3 Billion to Settle Marketing Case," New York Times, September 2, 2009, https://www.nytimes.com/2009/09/03/business/03health.html.

${ }^{209}$ David Ingram and Ros Krasny, "Johnson \& Johnson to Pay \$2.2 Billion to End US Drug Probes," Reuters, November 4, 2013, https://www.reuters.com/article/us-jnj-settlement/johnson-johnson-to-pay-2-2-billion-to-end-us-drug-probes-idUSBRE9A30MM20131104; Michael S. Schmidt and Katie Thomas, "Abbott Settles Marketing Lawsuit," New York Times, May 7, 2012, https://www.nytimes.com/2012/05/08/business/abbott-to-pay-1-6-billionover-illegal-marketing.html; Duff Wilson, "Merck to Pay $\$ 950$ Million over Vioxx," New York Times, November 22, 2011, https://www.nytimes.com/2011/11/23/business/merck-agrees-to-pay-950-million-in-vioxxcase.html?mtrref=www.google.com\&gwh=1BC21F897E6AB4EB0E7E6ABCA6D2EA34\&gwt=pay.

${ }^{210}$ US per capita spending on medicines exceeds $\$ 1,000$. See Statista, "Pharmaceutical spending per capita in selected countries as of 2017," https://www.statista.com/statistics/266141/pharmaceutical-spending-per-capita-inselected-countries/. See also QuintilesIMS Institute for Healthcare Informatics, Outlook for Global Medicines Through 2021: Balancing Cost and Value (December 2016).

211 Ibid., 49.

2122015 sales in "emerging markets" totaled 42 percent of global revenue for Abbott, 22.5 percent for Pfizer, 20 percent for Merck, and 26 percent for Johnson \& Johnson. Information on sales was collected from each company's 10-K filings with the SEC and the companies' public reports and public announcements.

${ }^{213}$ On the question of whether curing patients (as opposed to treating them) offers a sustainable business model, see Tae Kim, "Goldman Sachs Asks in Biotech Research Report: 'Is Curing Patients a Sustainable Business Model?,"” CNBC, April 11, 2018, https://www.cnbc.com/2018/04/11/goldman-asks-is-curing-patients-asustainable-business-model.html.

${ }^{214}$ Merck's anti-cancer drug Erbitux, however, only rose in tandem with the rising imported cost, and the price of Johnson \& Johnson's anti-cancer drug Velcade held steady. All statistics on Peru are drawn from Edson Meza Cornejo, Impacto de las exoneraciones arancelarias y tributaries en los precios de los medicamentos (Red Peruana por una Globalización con Equidad [Peruvian Network for Equitable Globalization] and the Centro Peruano de Estudios Sociales), http://www.redge.org.pe/sites/default/files/estudio_impacto_exoneraciones_web.pdf.

${ }^{215}$ David Hidalgo, "Farmacéuticas quieren bloquear por tercera vez ley que beneficiaría a cien mil pacientes," OjoPúblico, May 18, 2017, https://bigpharma.ojo-publico.com/articulo/farmaceuticas-quieren-bloquear-portercera-vez-ley-que-beneficiaria-a-cien-mil-pacientes/. 
${ }^{216}$ Fabio Torres López, Iván Herrera, and Mayté Ciriaco, “La vida tiene precio: farmacéuticas multinacionales deciden el acceso a la salud en América Latina," OjoPúblico, May 17, 2017, https://bigpharma.ojopublico.com/articulo/la-vida-tiene-precio/.

${ }^{217}$ Public services mitigate the impact of skewed income distribution by putting "virtual income" into the pockets of the poorest women and men. Oxfam, Working for the Many: Public Services Fight Inequality (2014),

https://www.oxfam.org/sites/www.oxfam.org/files/file_attachments/bp182-public-services-fight-inequality-030414summ-en_1.pdf.

${ }^{218}$ McKinsey Global Institute, Playing to Win: The New Global Competition for Corporate Profits (2015), http://www.mckinsey.com/business-functions/strategy-and-corporate-finance/our-insights/the-new-globalcompetition-for-corporate-profits, cited in Berkhout, Tax Battles.

219 Toplensky, "Multinationals Pay Lower Taxes Than a Decade Ago."

220 Ibid.

221 Tørsløv, Wier, and Zucman, "The Missing Profits of Nations."

222 UNCTAD, World Investment Report 2015.

${ }^{223}$ Niels Johannesen, Thomas Tørsløv, and Ludwig Wier, "Are Less Developed Countries More Exposed to Multinational Tax Avoidance? Method and Evidence from Micro-Data," WIDER Working Paper 2016/10 (UNUWIDER, 2016 [revised May 2017]), cited in Berkhout, Tax Battles.

${ }^{224}$ See Karin Steinberg, Dean Jamison, and Flavia Bustreo, "Advancing Social and Economic Development by Investing in Women's and Children's Health: A New Global Investment Framework," The Lancet 383, no. 9925, (April 12, 2014): 1333-54, http://www.thelancet.com/pdfs/journals/lancet/PIIS0140-6736(13)62231-X.pdf.

225 Johnson \& Johnson, "Our Credo."

${ }^{226}$ Johnson \& Johnson, “Tax Policy Statement,” https://www.jnj.com/about-jnj/company-statements/tax-policystatement.

${ }^{227}$ Vodafone, "Tax and Our Total Economic Contribution to Public Finances,"

https://www.vodafone.com/content/index/about/sustainability/operating-responsibly/tax-and-our-contribution-toeconomies.html.

${ }^{228}$ AngloAmerican, Tax and Economic Contribution Report 2015: Driving Change, Defining Our Future, http://southafrica.angloamerican.com/ /media/Files/A/Anglo-American-South-Africa-V2/documents/tax-andeconomic-contribution-report-interactice-2015-v2.pdf; Unilever, "Tax," https://www.unilever.com/sustainableliving/what-matters-to-you/tax.html; and SABMiller PLC, "Our Approach to Tax 2016," http://www.abinbev.com/content/dam/universaltemplate/ab-inbev/investors/sabmiller/reports/our-approach-to-tax-reports/taxreport-2016.pdf.

${ }^{229}$ Winnie Byanyima, "Business Leaders Raise the Bar on Corporate Tax Behavior," Inequality and Essential Services (blog), Oxfam, February 8, 2018, https://blogs.oxfam.org/en/blogs/18-02-08-business-leaders-raise-barcorporate-tax-behavior.

${ }^{230}$ The B Team, A New Bar for Responsible Tax: The B Team Responsible Tax Principles, http://bteam.org/wpcontent/uploads/2018/02/A-New-Bar-For-Responsible-Tax.pdf.

${ }^{231}$ Principles for Responsible Investment (PRI), "About the PRI," https://www.unpri.org/pri/about-the-pri; PRI, Evaluating and Engaging on Corporate Tax Transparency: An Investor Guide (2018),

https://www.unpri.org/download?ac=4668; and PRI, Engagement Guidance on Corporate Tax Responsibility: Why and How to Engage With Your Invested Companies (2015), https://www.unpri.org/download?ac=4536.

${ }^{232}$ A more detailed discussion of corporate responsibilities on tax can be found in Oxfam, ActionAid, and Christian Aid, Getting to Good: Towards Responsible Corporate Tax Behaviour (2015).

${ }^{233}$ Bureau Van Dijk, "Orbis: Company Information Worldwide," https://www.bvdinfo.com/en-us/ourproducts/company-information/internationalproducts/orbis?gclid=EAlaIQobChMIs7SM2MOD3AIVRUOGCh37cwsvEAAYASAAEgldh_D_BwE. 234 Berkhout, Tax Battles.

${ }^{235}$ An example of the problem of double counting is Pfizer in the Netherlands. One subsidiary (CP Pharmaceuticals International CV) is a holding company owning hundreds of other Pfizer subsidiaries around the world. Its total after-tax profit was 15.6 billion euros for the fiscal year ending on November 30, 2015, of which 14.5 billion euros was the consolidated profits of its subsidiaries, most of which from other countries. That 14.5 billion euro, together with the related revenues, is also reported in the subsidiaries' financial statements (when we 
could find them), and is counted toward Pfizer's profit margins both in the Netherlands and in the subsidiaries' home countries. It is striking that many of such large holding structures seem to be based in tax havens.

${ }^{236}$ For tax havens, we have supplemented data from subsidiaries' financial statements with data from the Orbis database.

${ }^{237}$ Owing to data limitations, we were not able to consolidate turnover and profit at the country level. That means that sales between subsidiaries of the same group in the same country are double-counted.

${ }^{238}$ Belgium has been a key profit-shifting destination, while also being a victim of profit-shifting to nearby tax havens such as the Netherlands or Luxembourg. The macroeconomic data that were used to build the Oxfam tax havens list therefore evened out, and Belgium fell outside of the top 15. See Berkhout, Tax Battles.

${ }^{239}$ In 2016, the European Commission determined that excess profit rulings are a form of illegal state aid. See European Commission, "State Aid: Commission Concludes Belgian 'Excess Profit' Tax Scheme Illegal; Around $€ 700$ Million to Be Recovered from 35 Multinational Companies," January 11, 2016, http://europa.eu/rapid/pressrelease_IP-16-42_en.htm. Belgium recently stopped issuing these types of rulings.

${ }^{240}$ European Commission, "Country Report Belgium 2018” (2018), https://ec.europa.eu/info/sites/info/files/2018european-semester-country-report-belgium-en.pdf. 
This paper was written by Mark Fried. Oxfam acknowledges the assistance of many Oxfam staff members, researchers, and policy advisors in Oxfam offices in more than 20 countries in its production.

For further information on the issues raised in this paper please email rsilverman@oxfamamerica.org.

This publication is copyright but the text may be used free of charge for the purposes of advocacy, campaigning, education, and research, provided that the source is acknowledged in full. The copyright holder requests that all such use be registered with them for impact assessment purposes. For copying in any other circumstances, or for re-use in other publications, or for translation or adaptation, permission must be secured and a fee may be charged. Email policyandpractice@oxfam.org.uk.

The information in this publication is correct at the time of going to press.

Published by Oxfam GB for Oxfam International under ISBN 978-1-78748-329-3 in September 2018.

DOI: $10.21201 / 2018.3293$

Oxfam GB, Oxfam House, John Smith Drive, Cowley, Oxford, OX4 2JY, UK.

\section{OXFAM}

Oxfam is an international confederation of 20 organizations working in 90 countries to build a future free from the injustice of poverty:

Oxfam America (www.oxfamamerica.org)

Oxfam Australia (www.oxfam.org.au)

Oxfam-in-Belgium (www.oxfamsol.be)

Oxfam Canada (www.oxfam.ca)

Oxfam France (www.oxfamfrance.org)

Oxfam Germany (www.oxfam.de)

Oxfam GB (www.oxfam.org.uk)

Oxfam Hong Kong (www.oxfam.org.hk)

Oxfam India (www.oxfamindia.org)

Intermón Oxfam (Spain) (www.intermonoxfam.org)

Oxfam Ireland (www.oxfamireland.org)

Oxfam Italy (www.oxfamitalia.org)

Oxfam Japan (www.oxfam.jp)

Oxfam Mexico (www.oxfammexico.org)

Oxfam New Zealand (www.oxfam.org.nz)

Oxfam Novib (Netherlands) (www.oxfamnovib.nl)

Oxfam Québec (www.oxfam.qc.ca)

Please write to any of the agencies for further information, or visit www.oxfam.org. 